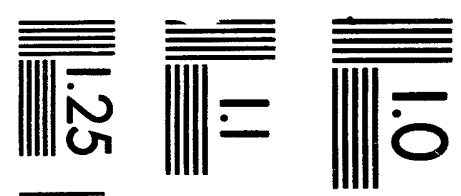

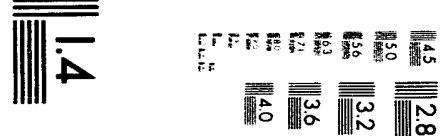

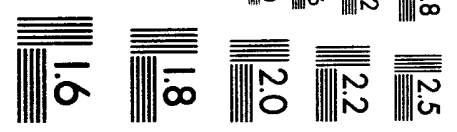



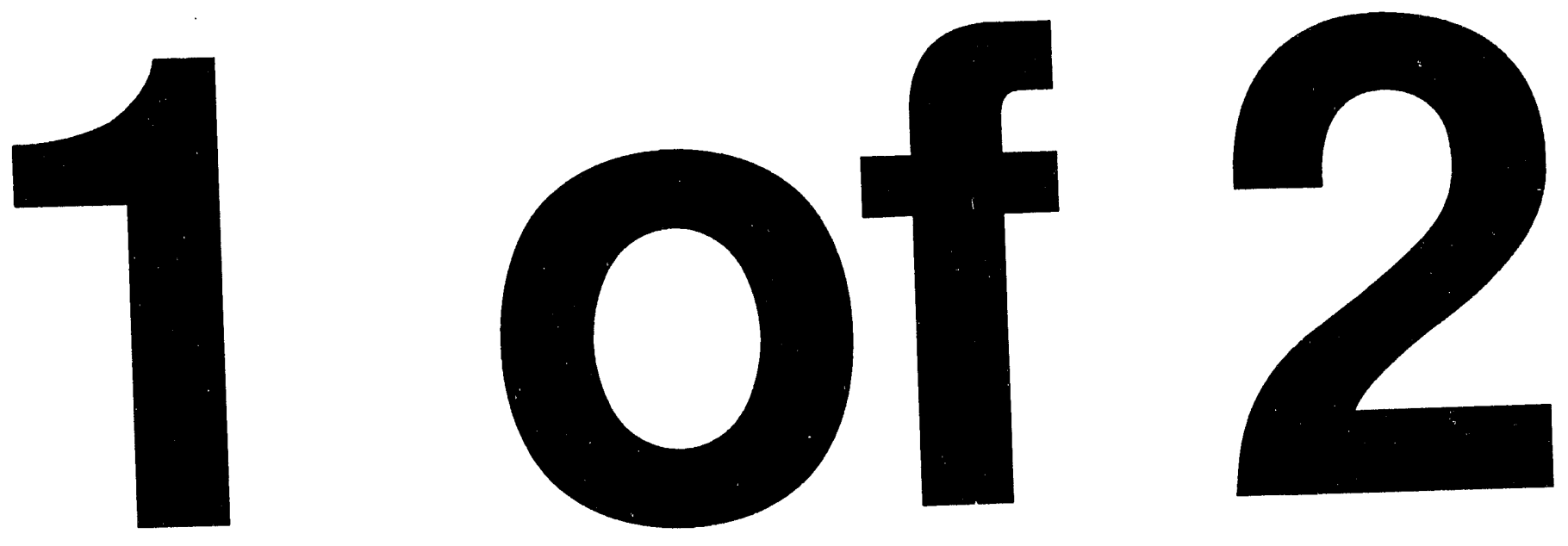


\section{Quarterly Report on Defense Nuclear Facilities Safety Board Recommendation 90-7 for the Period Ending June 30, 1993}
R. J. Cash
G. T. Dukelow
C. J. Forbes
J. E. Meacham

Date Published

October 1993

Prepared for the U. S. Department of Energy Office of Environmental Restoration and Waste Management

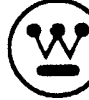

Westinghouse Hanford Company Richland. Washington 99352

Hantord Operations and Engineering Contractor for the

US Department of Energy under Contract DE ACO6.87RL10930 


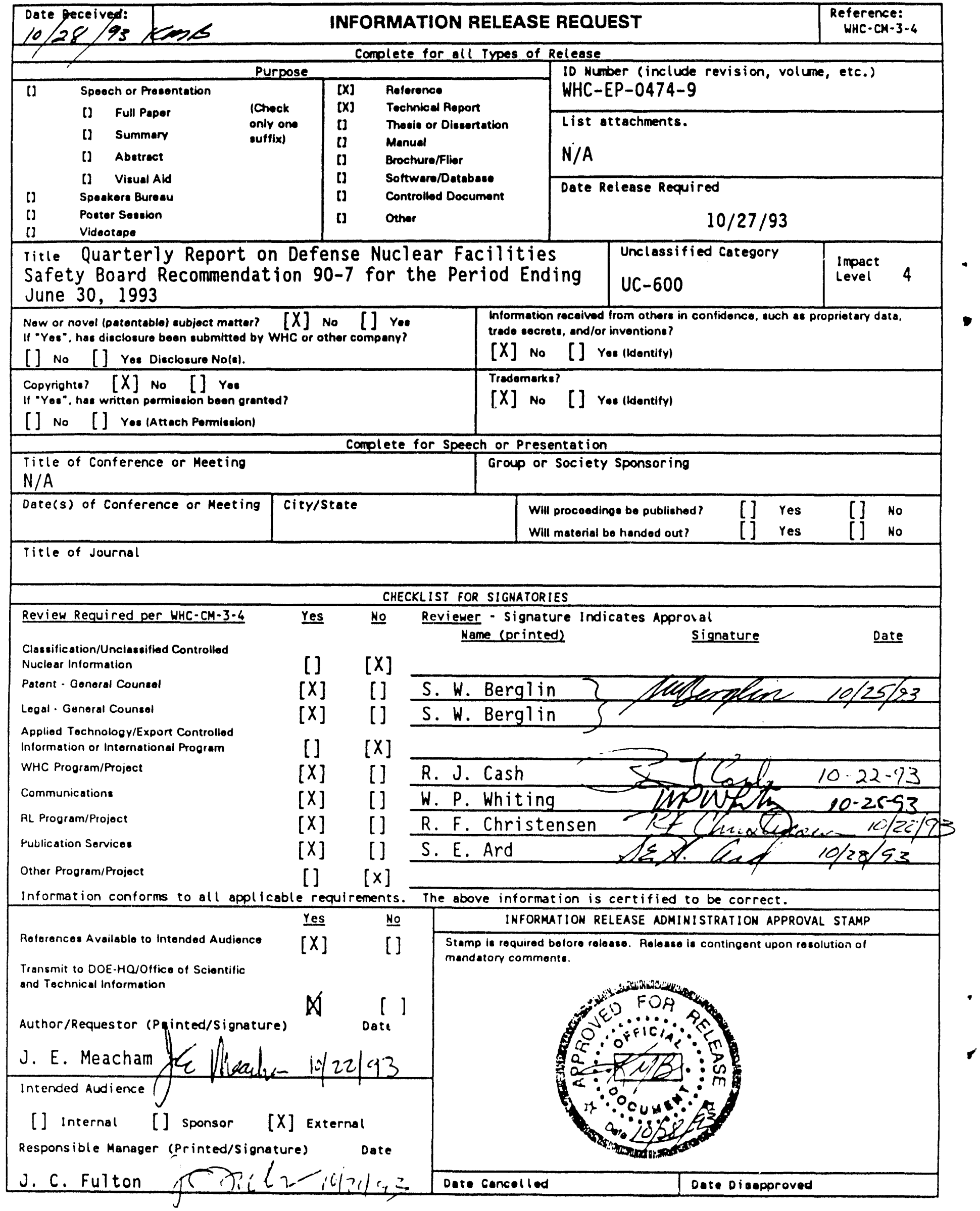




\title{
QUARTERLY REPORT ON DEFENSE NUCLEAR FACILITIES SAFETY BOARD RECOMMENDATION 90-7 FOR THE PERIOD ENDING JUNE 30, 1993
}

\author{
R. J. Cash \\ G. T. Dukelow \\ J. E. Meacham
}

\section{EXECUTIVE SUMMARY}

This is the ninth quarterly report on the progress of activities that address safety issues associated with Hanford Site high-level radioactive waste tanks containING ferrocyanide compounds. In the presence of oxidizing materials, such as nitrates or nitrites, ferrocyanide can be made to explode in the laboratory by heating it to high temperatures labove $285^{\circ} \mathrm{C}$ $\left(545^{\circ} \mathrm{F}\right) \mathrm{J}$. In the mid 1950s, approximately 140 metric tons of ferrocyanide were added to waste now stored in underground high-level radioactive waste tanks. An implementation plan (Cash 1991) that responds to the Defense Nuclear Facilities Safety Board Recommendation 90-7 (FR 1990) ${ }^{2}$ was issued in March 1991 describing the activities that were planned and underway to address each of the six parts of Recommendation 90-7. $A$ revision to the original plan was transmitted to the U.S. Department of Energy by Westinghouse Hanford Company in December 1992.

The revised implementation plan describes the progress made on Ferrocyanide Safety Program activities since the beginning of the program in September 1990, as well as those continuing tasks that address or supplement the six parts of Recommendation 90-7. The revised plan provides an updated schedule, and includes the current status of understanding on the ferrocyanide safety issue. The document was approved for public availability.

Milestones completed this quarter include (1) a report on the credibility of hot spots and a recommendation on infrared scans; (2) a document discussing the strength and limitations of proposed moisture monitoring technologies; (3) limited calibration of the neutron probe in simulant-filled drums; (4) a report interpreting data from auger surface samples of ferrocyanide tank 241-BY-104; (5) a document on the effect of possible catalyst, initiator, and diluents on ferrocyanide reactivity; (6) a report on small-scale sensitivity tests of ferrocyanide flowsheet simulants; and (7) preparation and shipment of $T$ Plant simulants for calorimetric and dryout tests.

The thermocouple tree installed in tank 241-BY-111 last quarter stopped two feet, nine inches from the bottom of the tank. An evaluation was performed to determine if this thermocouple tree would be adequate for monitoring temperatures in the tank. A sufficient number of 
thermocouples are in the waste and the temperatures received from the tree to date are consistent with temperature data obtained from thermocouples placed in the liquid observation well. Based upon the evaluation performed, the thermocouple tree will be adequate for monitoring as installed and no further attempts to lower the tree will be made. A document discussing the probability of a hot spot within the ferrocyanide tanks was released this quarter, titled Ferrocyanide Safety Program: Credibility of Drving Out Ferrocyanide Tank Waste by Hot Spots (Dickinson et al. 1993). The report concludes that the existence or formation of a hot spot is incredible. The report further states that the probability of hot spots existing is too low to warrant infrared scanning to detect potential hot spots.

A Raman spectroscopy system was installed in the 222-S Hot Cell Facility. Preliminary Raman spectra were obtained in a glovebox using low level waste material from nonferrocyanide tanks 241-BX-107 and 241-T-111. No interferences or background fluorescence have been encountered to date with the various core segments analyzed to date.

$T$ Plant simulant was prepared and shipped to various laboratories for characterization and reactivity testing. The simulant formed three distinct layers after centrifuging to mimic 30 years of settling. The layers consisted of a bottom white or tan layer of about 9 volume percent, a middle brown layer of about 83 volume percent, and a top grey layer of about 8 volume percent. The middle and top layers exhibited similar exothermic properties during differential scanning calorimetry tests at Westinghouse Hanford Company. The bottom layer exhibited no exothermic properties.

A report discussing the effects of possible catalysts, initiators, and diluents found in Hanford Site single-shell waste tanks was released this quarter. Sodium sulfide, added to some of the single-shell tanks to scavenge Cobalt 60 as cobalt sulfide, was found to lower the initiating reaction temperature from $280^{\circ} \mathrm{C}$ to $260^{\circ} \mathrm{C}$. However, this temperature is still $200{ }^{\circ} \mathrm{C}$ greater than the highest ferrocyanide tank temperature (approximately $55^{\circ} \mathrm{C}$ ).

A report on small-scale sensitivity tests of ferrocyanide flowsheet simulants was published by Los Alamos National Laboratory in June. These tests demonstrated that a propagating reaction could not be initiated in dried In Farm simulant by non-thermal shock or impact.

1. Cash, R. J., 1991, Implementation Plan for the Defense Nuclear Facilities Safety Board Recommendation 90-7, WHC-EP-0415, Westinghouse Hanford Company, Richland, Washington.

2. FR, 1990, Implementation Plan for Recommendation 90-3 at the Department of Energy's Hanford Site. WA, Federal Register, DNFSB Recommendation 90-7, Vol. 55, No. 202, pp. 42243-44.

3. Dickinson, D. R., J. M. McLaren, G. L. Borsheim, and M. D. Crippen, 1993, Ferrocyanide Safety Program, Credibility of Drying Out Ferrocyanide Tank Waste By Hot Spots, WHC-EP-0648, Rev. 0, Westinghouse Hanford Company, Richland, Washington. 
CONTENTS

1.0 INTRODUCTION $\ldots \ldots \ldots \ldots \ldots \ldots \ldots \ldots \ldots \ldots \ldots \ldots \ldots \ldots \ldots \ldots \ldots .1-1$

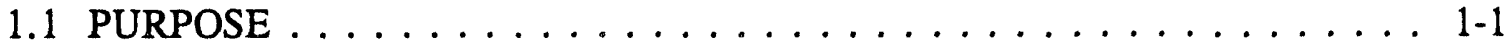

1.2 QUARTERLY HIGHLIGHTS $\ldots \ldots \ldots \ldots \ldots \ldots \ldots \ldots \ldots \ldots$ 1-1

1.3 REPORT FORMAT $\ldots \ldots \ldots \ldots \ldots \ldots \ldots \ldots \ldots \ldots$

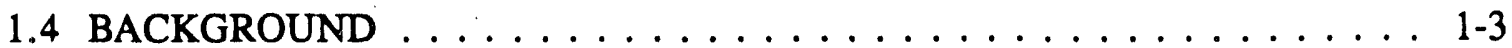

2.0 DEFENSE NUCLEAR FACILITIES SAFETY BOARD

IMPLEMENTATION PLAN TASK ACTIVITIES . . . . . . . . . . 2-1

2.1 DEFENSE NUCLEAR FACILITIES SAFETY BOARD

RECOMMENDATION 90-7.1 (ENHANCED

TEMPERATURE MEASUREMENT) $\ldots \ldots \ldots \ldots \ldots \ldots \ldots \ldots . \ldots . \ldots \ldots$

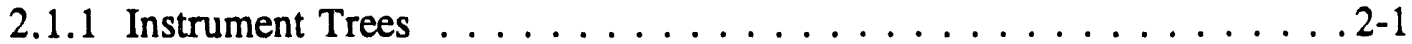

2.1.2 Upgrades to Existing Tank Temperature

Monitoring Instrumentation . . . . . . . . . . . . . . . . . . 2-5

2.1.3 Alternate Monitoring Technologies . . . . . . . . . . . 2-5

2.1.4 Hot Spot Thermal Modeling . . . . . . . . . . . . . . . 2-22

2.2 DEFENSE NUCLEAR FACILITIES SAFETY BOARD

RECOMMENDATION 90-7.2 (CONTINUOUS

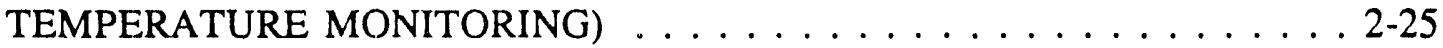

2.2.1 Tank Monitoring and Control System . . . . . . . . . . . . 2-25

2.3 DEFENSE NUCLEAR FACILITIES SAFETY BOARD

RECOMMENDATION 90-7.3 (COVER GAS MONITORING) . . . . . . . 2-24

2.3.1 On-Line Gas Monitoring . . . . . . . . . . . . . . . . 2-25

2.3.2 Interim Flammable Gas Monitoring . . . . . . . . . . . . 2-25

2.3.3 Vapor Space Gas Modeling . . . . . . . . . . . . . . 2-26

2.4 DEFENSE NUCLEAR FACILITIES SAFETY BOARD

RECOMMENDATION 90-7.4 (FERROCYANIDE

WASTE CHARACTERIZATION) . . . . . . . . . . . . . . 2-28

2.4.1 Ferrocyanide Tank Waste Sampling and

Characterization . . . . . . . . . . . . . . . . . . 2-28

2.4.2 Simulated Ferrocyanide Waste Preparation and

Characterization . . . . . . . . . . . . . . . . . . 2-33

2.4.3 Position Paper on Safety of Ferrocyanide Tanks . . . . . . . . 2 2-38

2.4.4 Ferrocyanide Waste Tanks Hazards Assessment . . . . . . . . . 2-40

2.4.5 Closure of the Ferrocyanide Unreviewed

Safety Question . . . . . . . . . . . . . . . . . . 2-41

2.4.6 Concepts for Resolution of the Ferrocyanide Safety Issue . . . . . . 2-45

2.5 DEFENSE NUCLEAR FACILITIES SAFETY BOARD

RECOMMENDATION 90-7.5 (CHEMICAL

REACTION STUDIES) $\ldots \ldots \ldots \ldots \ldots \ldots \ldots \ldots$. . . . . . . . . . . . . . . . 


\section{CONTENTS (Continued)}

2.5.1 Chemical Reaction Studies at Pacific

Northwest Laboratory . . . . . . . . . . . . . . . . . . . 2-47

2.5 .2 Ferrocyanide Propagation Studies . . . . . . . . . . 2-55

2.6 DEFENSE NUCLEAR FACILITIES SAFETY

BOARD RECOMMENDATION 90-7.6

(EMERGENCY RESPONSE PLANNING) . . . . . . . . . . . 2-58

2.6.1 Action Plan for Response to Abnormal Conditions . . . . . . . 2 2-58

2.6.2 Response to an Airborne Release

From a Ferrocyanide Tank . . . . . . . . . . . . . . . 2-60

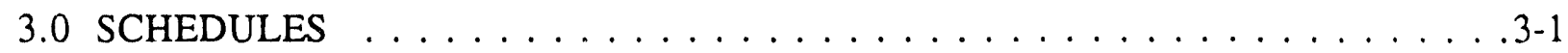

4.0 REFERENCES . . . . . . . . . . . . . . . . . . . . 4-1

APPENDIX

LIST OF FERROCYANIDE TANKS $\ldots \ldots \ldots \ldots \ldots \ldots \ldots$ App-1 


\section{LIST OF FIGURES}

2-1 Thermocouple Tree Boring Head Design $\ldots \ldots \ldots \ldots . \ldots \ldots$

2-2 Cutaway View of New Thermocouple Tree Showing Internal Features . . . . . . 2-3

2-3 Comparison of Measured Values and MCNP Model Detector Responses

With the Neutron Probe Immersed in Water . . . . . . . . . . . . . . 2-9

2-4 Comparison of Measured Values and MCNP Modeled Detector Responses

With the Neutron Probe Inside an LOW Immersed in Water . . . . . . . . . . . 2-10

2-5 Comparison of Measured Values and MCNP Modeled Detector Responses

With the Neutron Probe Deployed in Moisture Standards . . . . . . . . . . . . . 2-12

2-6 Comparison of Measured Values and MCNP Modeled Detector Responses

for Two Source-to-Detector Separations . . . . . . . . . . . . . . . . . . . 2-13

2-7 Comparison of Measured and MCNP Modeled Response Ratios for

Two Source-to-Detector Separations . . . . . . . . . . . . . . . 2-14

2-8 Raman Spectra From Tank 241-BX-107 Waste Tank Core Samples

(Cores 40 and 41) For the Nitrate-Active Spectral Region . . . . . . . . . . . . 2-20

2-9 Thermal and Gas Reluase Analyses for T Plant

Middle Fraction Simulant . . . . . . . . . . . . . . . . . . . . 2-36

2-10 Thermal and Gas Release Analyses for T Plant

Top Fraction Simulant . . . . . . . . . . . . . . . . . . . . . . . 2-37

2-11 Dissolution of Vendor Material in Aqueuus pH 13

Solution Containing 1 Molar Sodium Ion . . . . . . . . . . . . . . . 2-48

2-12 Solubility of In Farm 2 and Vendor Prepared

Ferrocyanide Materials at $\mathrm{pH} 13$ and $14 \ldots \ldots$. . . . . . . . . . . . . . . . . .

2-13 Relative Concentration of Free Cyanide in Solution Containing

Potential Interferants Compared to Free Cyanide Standard . . . . . . . . . . . . . 2-51 


\section{LIST OF TABLES}

2-1 Major Analytes for Tank 241-C-109, Cores 47, 48, and $49 \ldots \ldots$. . . . . . . . .

2-2 Comparison of 5 percent EDTA/en solution and Sodium Hydroxide Dissolution of Sodium Nickel Ferrocyanide and Cesium Nickel Ferrocyanide 


\section{LIST OF TERMS}

\begin{tabular}{|c|c|}
\hline ATR & Attenuated Total Reflectance \\
\hline CASS & Computer Automated Surveillance System \\
\hline CCD & Charged Coupled Device \\
\hline $\mathrm{cm}$ & centimeters \\
\hline $\mathrm{CN}^{-}$ & Free Cyanide \\
\hline${ }^{60} \mathrm{Co}$ & Cobalt 60 \\
\hline $\begin{array}{l}\text { CPAC } \\
{ }_{137} \mathrm{Cs}\end{array}$ & Center for Process Analytical Chemistry \\
\hline DNFSB & Cesium 137 \\
\hline DOE & $\begin{array}{l}\text { Defense Nuclear Facilities Safety Board } \\
\text { U.S. Department of Energy }\end{array}$ \\
\hline DOE-EM & $\begin{array}{l}\text { U.S. Department of Energy } \\
\text { U.S. Department of Energy - Environmental Restoration and } \\
\text { Waste Management }\end{array}$ \\
\hline DOE-RL & U.S. Department of Energy, Richland Operations Office \\
\hline DSC & Differential Scanning Calorimetry \\
\hline EA & Environmental Assessment \\
\hline EDTA & Ethylenediaminetetraacetic Acid \\
\hline FAI & Fauske and Associates, Inc. \\
\hline en & ethylenediamine \\
\hline EPA & Environmental Protection Agency \\
\hline FSU & Florida State University \\
\hline FY & Fiscal Year \\
\hline HEDTA & Hydroxyethylenediaminetriacetic Acid \\
\hline HEPA & High-Efficiency Particulate Air \\
\hline $\mathrm{Hg}$ & Mercury \\
\hline IC & Ion Chromatography \\
\hline $\mathrm{JCO}$ & Justification for Continued Operations \\
\hline $\mathrm{L}$ & liters \\
\hline LANL & Los Alamos National Laboratory \\
\hline LLNL & Lawrence Livermore National Laboratory \\
\hline LOW & Liquid Observation Well \\
\hline$\underline{\mathrm{M}}$ & Molar \\
\hline MCNP & Monte Carlo Neutron Photon [Model] \\
\hline MIT & Multifunctional Instrument Tree \\
\hline $\mathrm{mm}$ & millimeters \\
\hline $\mathrm{mw}$ & milliwatts \\
\hline NIR & Near Infrared \\
\hline $\mathrm{nm}$ & nanometer \\
\hline PNL & Pacific Northwest Laboratory \\
\hline PSO & Program Secretarial Officer \\
\hline SA & Safety Assessment \\
\hline SAR & Safety Analysis Report \\
\hline${ }^{90} \mathrm{Sr}$ & Strontium 90 \\
\hline
\end{tabular}




\section{LIST OF TERMS (Continued)}

SRL

SST

TAMMO

TAP

TC

TMACS

TPA

TTX

USQ
Savannah River Laboratory

Single-Shell Tank

Tank Moisture Model

Tanks Advisory Panel

Thermocouple

Tank Monitor and Control System

Tri-Party Agreement, Hanford Federal Facility Agreement

and Consent Order

Time to Explosion

Unreviewed Safety Question 


\section{QUARTERLY REPORT ON DEFENSE NUCLEAR FACILITIES SAFETY BOARD RECOMMENDATION 90-7 FOR THE PERIOD ENDING JUNE 30, 1993}

\subsection{INTRODUCTION}

\subsection{PURPOSE}

This quarterly report provides a status of the activities underway at the Hanford Site on ferrocyanide waste tank safety issues, as requested by the Defense Nuclear Facilities Safety Board (DNFSB) in their Recommendation 90-7 (FR 1990). In March 1991, a DNFSB Implementation Plan (Cash 1991) responding to the six parts of Recommendation 90-7 was prepared and sent to the DNFSB. The plan was revised and forwarded to the U.S. Department of Energy (DOE) in December 1992 for transmittal to the DNFSB (Borsheim et al. 1992). All activities in the revised DNFSB Implementation Plan are underway, or have been completed; and the status of each is described in Section 2.0 of this report.

\subsection{QUARTERLY HIGHLIGHTS}

- As reported last quarter, the thermocouple (TC) tree installed in tank 241-BY-111 stopped two feet, nine inches from the bottom of the tank. An evaluation was performed to determine if this thermocouple tree would be adequate for monitoring temperatures in the tank. A sufficient number of thermocouples contained in the tree are in the waste and the temperature data received from the tree to date are consistent with temperature data obtained from thermocouples placed in the liquid observation well. Based upon the evaluation performed, the TC tree will be adequate for monitoring as installed and no attempt to lower the TC tree will be made.

- A heated vapor sampling tube has been added to the new thermocouple tree design. This added feature of the new thermocouple tree may eliminate the need to install an additional vapor probe, which is presently required to obtain vapor space gas samples. Vapor sampling using the thermocouple tree could reduce field efforts and the cost of vapor space characterization. 
- A document discussing the probability of a hot spot within the ferrocyanide tanks was released this quarter, titled "Ferrocyanide Safety Program: Credibility of Drying Out Ferrocyanide Tank Waste by Hot Spots" (Dickinson et al. 1993). The report concludes that the existence or formation of a hot spot is incredible. The report further states that the probability of hot spots existing is too low to warrant the use of infrared scanning to detect potential hot spots.

- A report that reviews the strengths and limitations of proposed moisture monitoring technologies was released this quarter, titled Moisture Monitoring of Ferrocyanide Tanks: An Evaluation of Methods and Tools (Meacham et. al. 1993). Three technologies, neutron diffusion, near-infrared spectroscopy, and Raman spectroscopy were evaluated. This report concludes that all of the moisture monitoring technologies have strengths and limitations, however, the neutron probe shows the most promise as a reliable form of moisture monitoring system in the near future.

- A Raman spectroscopy system was installed in the 222-S Hot Cell Facility. Preliminary Raman spectra were obtained in a glove box using low level waste material from tanks 241-BX-107 and 241-T-111. No interferences or background fluorescence have been encountered to date with the various core segments analyzed to date.

- The Florida State University (FSU) Raman feasibility study contract has been renewed. The expanded work scope includes developing a speciation algorithm for ferro/ferricyanides and exploratory spectra work with waste tank organics. FSU will provide archive spectra for Westinghouse Hanford Company to use in their hot cell and in situ waste tank characterization Raman campaigns.

- A data interpretation report for the two auger surface samples taken from tank 241-BY-104 was released to the public this quarter, titled Data Interpretation Report on Tank 24l-BY-104 Auger Samples (Neskas and Borsheim 1993). The moisture concentration of the surface crust ranged from 15 to 17 weight percent. The crust was not rigid and crumbled easily during auger sampling. As expected, values for the heat of reaction were quite low and propagating reactions could not be initiated in the sample.

- T Plant simulant was prepared and shipped to various laboratories for characterization and reactivity testing. The simulant formed three distinct layers after centrifuging to mimic 30 years of settling. The layers consisted of a bottom white or tan layer of about 9 volume percent, a middle brown layer of about 83 volume percent, and a top grey layer of about 8 volume percent. 
- A report that discusses the effects of possible catalysts, initiators, and diluents found in some Hanford Site single-shell waste tanks (SSTs) was released this quarter, titled Effect of Potential Waste Constituents on the Reactivity of Ferrocyanide Wastes: Catalyst, Initiator and Diluent Studies (Scheele et al. 1993). Sodium sulfide, added to some of the SSTs to cobalt-60 as cobalt sulfide, scavenge strontium, was found to lower the initiating reaction temperature from $280{ }^{\circ} \mathrm{C}$ to $260^{\circ} \mathrm{C}$. However, this temperature is still $200{ }^{\circ} \mathrm{C}$ greater than the highest ferrocyanide tank temperature (approximately $55^{\circ} \mathrm{C}$ ).

- A report on small-scale sensitivity tests of ferrocyanide flowsheet simulants was published by Los Alamos National Laboratory (LANL) in June, titled Evaluation of Ferrocyanide/Nitrate Explosive Hazard (Cody 1993). These tests demonstrated that a propagating reaction could not be initiated in dried In Farm simulant (the most reactive) by mechanical shock or impact.

\subsection{REPORT FORMAT}

The quarterly reports on progress of activities under each of the six parts of DNFSB Recommendation 90-7 are arranged in the same order as the original DNFSB Implementation Plan (Cash 1991) and the revised DNFSB Implementation Plan (Borsheim et al. 1992). The arrangement also follows the same order provided in the recommendation. To report on progress, each part of the recommendation is repeated in italics, followed by paragraphs explaining the scope of work on each part or subpart of the recommendation. Subheadings for each task activity report the following items of progress:

- Progress During Reporting Period

- Planned Work for Subsequent Months

- Problem Areas and Action Taken

- Milestone Status.

\subsection{BACKGROUND}

Radioactive wastes from defense operations have accumulated at the Hanford Site in underground waste tanks since the early 1940s. During the 1950s, additional tank storage space was required to support the Hanford Site defense mission. To obtain this additional storage volume within a short period of time, and without constructing additional storage tanks, Hanford Site scientists developed a process to scavenge radiocesium and other soluble radionuclides from tank waste liquids. As a result of implementing this process, approximately 140 metric tons of ferrocyanide were added to a number of SSTs.

Ferrocyanide is a complex of ferrous ion and cyanide that is considered nontoxic because it is stable in aqueous solutions. However, in the presence of oxidizing materials, such as nitrates and nitrites, near-stoichiometric amounts of ferrocyanide can explode under special conditions in the laboratory by (1) heating to high temperatures (above $285^{\circ} \mathrm{C}$ ), or (2) by an electrical spark of sufficient energy to heat the mixture. The explosive nature of ferrocyanide in the presence of an oxidizer has been known for decades, but the conditions 
under which the compound can undergo an exothermic reaction have not been thoroughly studied. Because the scavenging process involved precipitating ferrocyanide from solutions containing nitrate*, it is likely that an intimate mixture of ferrocyanides with nitrates and nitrites exists in parts of some of the SSTs.

Efforts have been underway since the mid-1980s to evaluate the potential for a ferrocyanide reaction in the Hanford Site SSTs (Burger 1989, Burger and Scheele 1988). In 1987, the final environmental impact statement for disposal of Hanford Site waste farms was issued (DOE 1987). The environmental impact statement projected that the bounding "worst-case" accident in a ferrocyanide tank would be an exothermic reaction resulting in a subsequen: short-term radiation dose to the public of approximately $200 \mathrm{mrem}$.

A General Accounting Office study (Peach 1990) postulated a greater "worst-case" accident, with independently-calculated doses one to two orders of magnitude greater than the 1987 DOE environmental impact statement. A special Hanford Site Ferrocyanide Task Team was commissioned in September 1990 to address all issues involving the ferrocyanide tanks, including the consequences of a potential accident. On October 9, 1990, then Secretary of Energy James D. Watkins announced that a supplemental environmental impact statement would be prepared containing an updated analysis of safety questions for the Hanford Site SSTs, including analysis of a ferrocyanide explosion (DOE 1990).

Using process knowledge and historical records, $24^{* *}$ tanks were identified at the Hanford Site that contain $1,000 \mathrm{~g}$-mole or more of ferrocyanide as the $\mathrm{Fe}(\mathrm{CN})_{6}^{4}$ radical. In October 1990, the ferrocyanide issue was declared an Unreviewed Safety Question*** because the safety envelope for these tanks may no longer be bounded by the existing safety analysis report (Bergmann 1986) and the 1987 DOE environmental impact statement. Work in and around any of the ferrocyanide tanks requires detailed planning, together with the preparation of supporting safety and environmental documentation, and approval by DOE management. These restrictions are required for safety and significantly increase the time required to complete work or install equipment in the tanks.

*Nitrite $\left(\mathrm{NO}_{2}\right)$ is formed in the tanks from radiolysis of the nitrate $\left(\mathrm{NO}_{3}^{-}\right)$. The ratio of $\mathrm{NO}_{2}^{-} / \mathrm{NO}_{3}$ is approximately $3: 1$ in the ferrocyanide tanks.

**Two more tanks that potentially contain ferrocyanide were identified since the DOE responded to Recommendation 90-7 1990 (FR 1990).

***An Unreviewed Safety Question, as defined by DOE Orders 5480.5 (DOE 1986) and 5480.21 (DOE 1991), follows. "A proposed change, test or experiment shall be deemed to involve an Unreviewed Safety Question if:

- The probability of occurrence or the consequences of an accident or malfunction of equipment important to safety, evaluated previously by safety analysis will be significantly increased, or

- A possibility for an accident or malfunction of a different type than any evaluated previously by safety analysis will be created which could result in significant safety consequences." 


\subsection{DEFENSE NUCLEAR FACILITIES SAFETY BOARD IMPLEMENTATION PLAN TASK ACTIVITIES}

The revised DNFSB Implementation Plan (Borsheim et al. 1992) addresses each task activity that was established in response to the six parts of DNFSB Recommendation 90-7. In this plan, each part of the recommendation is stated and then progress of Hanford Site activities relating to that part is described.

\subsection{DEFENSE NUCLEAR FACILITIES SAFETY BOARD RECOMMENDATION 90-7.1 (ENHANCED TEMPERATURE MEASUREMENT)}

"Immediate steps should be taken to add instrumentation as necessary to the SSTs containing ferrocyanide that will establish whether hot spots exist or may develop in the future in the stored waste. The instrumentation should include, as a minimum, additional thermocouple trees. Trees should be introduced at several radial locations in all tanks containing substantial amounts of ferrocyanide, to measure the temperature as a function of elevation at these radii. The use of infrared techniques to survey the surface of waste in tanks should continue to be investigated as a priority matter, and on the assumption that this method will be found valuable, monitors based on it should be installed now in the ferrocyanide bearing tanks."

\subsubsection{Instrument Trees}

DNFSB Recommendation 90-7.1 requests that actions be taken to add instrumentation to the ferrocyanide waste tanks to measure waste temperatures and to determine if hot spots exist or may develop.

A strategy was initially developed to provide the temperature instrumentation necessary to monitor conditions in five high concern waste tanks on an expedited basis. The strategy was to (1) repair the existing TCs (where possible); (2) install new TC trees that would be fabricated from existing drawings; and (3) install multifunctional instrument trees (MITs) in those tanks that have a limited number of risers available. The MITs would provide temperature monitoring, the capability for gas sampling at three elevations, possible pressure monitoring, and access for deployment of fiber optics inside the tanks if desired. The TC trees would provide temperature monitoring but may not provide the option to obtain any additional data. This strategy was later revised to include only repair of existing TC trees and installation of new TC trees in ferrocyanide waste tanks. There are no plans to install MITs in the ferrocyanide tanks at this time. 
- Progress During Reporting Period. As reported last quarter, the TC tree that was installed in tank 241-BY-111 in March stopped two feet, nine inches from the bottom of the tank when it hit either a hard waste layer or a failed piece of equipment. An evaluation was performed to determine if the TC tree was adequate for monitoring (McLaren 1993). The evaluation determined that the TC tree is adequate for monitoring as installed and no further effort to lower the tree will be made.

The ultra high-pressure boring head for installing TC trees into assumed leaker tanks has been designed and ordered. A special method for installing TC trees required for these tanks in order to minimize the amount of water added to the tank. The final boring head design is shown in Figure 2-1. An acceptance test was completed for the ultra high-pressure sysiem and the test verified that the final hardware performs as expected. This head design uses less than 200 liters (L) (50 gal) of water whereas the conventional method of sluicing in the tree co:dld use up to 5,700 L (1500 gal).

Figure 2-1. Thermocouple Tree Boring Head Design.

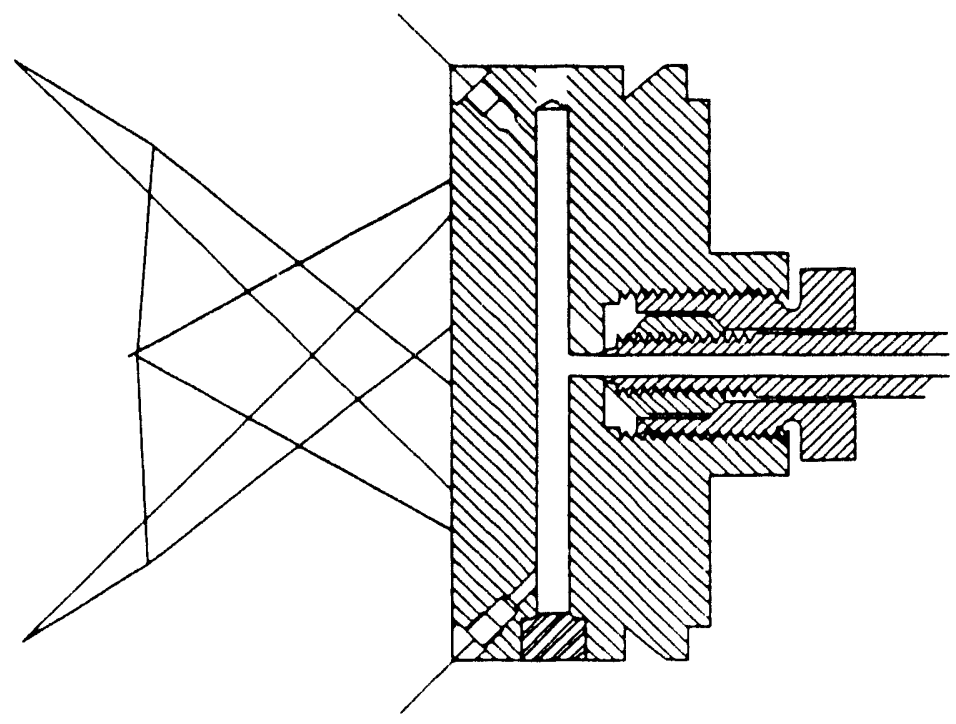

A heated vapor sampling tube has been added to the new TC tree design. The heated tube extends from outside the riser, through the TC tree and into the dome space of the tanks (Figure 2-2). The tube will be heated by circulating either hot water or hot gas around the sampling tube. This added feature of the new TC tree may eliminate the need to install an additional vapor probe, which is presently required to obtain vapor space gas samples. Vapor sampling using the TC tree could reduce field efforts and the cost of vapor space characterization. 
Figure 2-2. Cutaway View of New Thermocouple Tree Showing Internal Features.

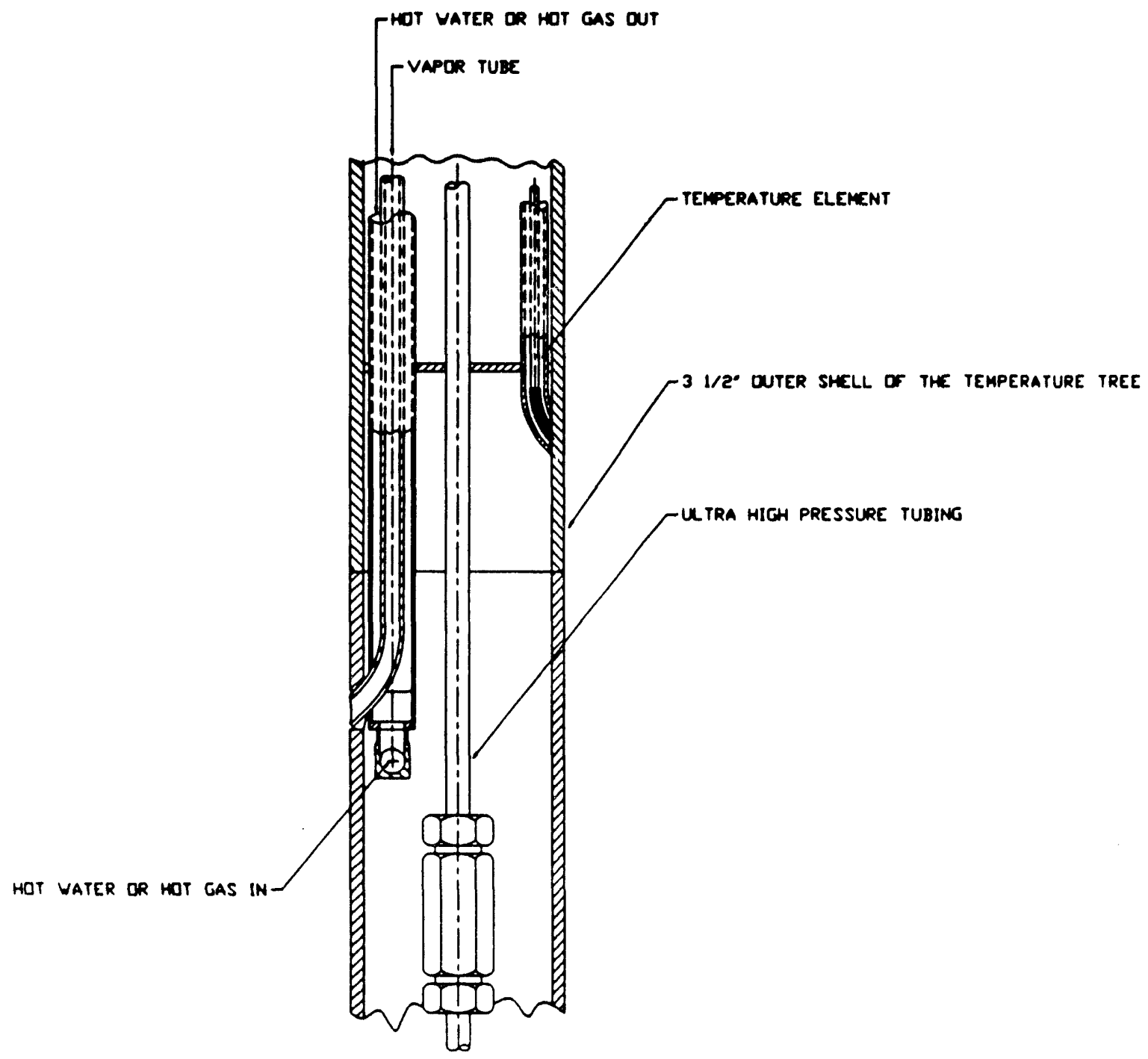

Planning continued for installation of TC trees in the assumed leaker tanks. Safety documentation that supports installation of TC trees into the 14 assumed leaker ferrocyanide tanks was completed and transmitted to DOE for approval. The environmental assessment was also completed and transmitted to DOE for approval this quarter. 
- Planned Work for Subsequent Months. To date, six new TC trees have been installed in the following ferrocyanide tanks: $241-\mathrm{BY}-104,-110,-11 \mathrm{i},-112$, 241-C-109, and -112 . Installation of TC trees in the last four non-leaking ferrocyanide tanks (241-BX-106, 241-BY-101, 241-C-108, and 241-TX-118) is scheduled for completion by July 30, 1993.

TC trees for the first four assumed leaker tanks will be fabricated using the heated vapor sampling tube by September 1993.

- Problem Areas and Action Taken. To install equipment such as TC trees into waste tanks, water is normally used to sluice in the equipment to the desired depth. Water additions to ferrocyanide tanks that are classified as assumed leakers raise an environmental issue that waste could leak from the tank. The next four tanks to receive new TC trees are listed as sound, however, 14 of the 24 ferrocyanide tanks are classified as assumed leakers. It is feasible to reduce the amount of water used to install thermocouple trees to an acceptable amount ( $<760$ L [200 gal]) using the high pressure bore head.

\section{- Milestone Status -}

- May 29, 1992: Install first new TC tree in a ferrocyanide tank, and three additional TC trees by September 30, 1992. The first installation was delayed because the safety and environmental documentation took longer than anticipated for review by the DOE and Westinghouse Hanford Company. The first new TC tree was installed in September 1992.

- September 30, 1992: Install additional TC trees in three ferrocyanide tanks. Three additional TC trees were installed in September 1992 (total of four new TC trees).

- March 30, 1993: Submit safety and environmental documentation to the DOE for installation of TC trees in assumed leaker ferrocyanide tanks. The safety assessment was completed and transmitted on April 5, 1993. The environmental assessment was finalized and transmitted on June 21, 1993.

- July 30, 1993: Complete installation of an additional six TC trees in non-leaker tanks. Two of the six (241-BY-111 and -112) were installed in March. This milestone remains on schedule.

- September 30, 1994: Complete installation of TC trees in assumed leaker tanks. 


\subsubsection{Upgrades to Existing Tank Temperature Monitoring Instrumentation}

This task determined the operability and accuracy of presently installed TCs in the ferrocyanide tanks at the Hanford Site. Existing TCs are used to provide temperature readings for the ferrocyanide tanks along with the new TC trees as they are installed.

Field measurements were taken in 1991 on each TC in the existing trees to determine the resistance and voltage across the junction and across each lead to ground. The exact condition of each TC was determined by the resistance and voltage measurements (Bussell 1991). This work was completed in fiscal year (FY) 1991 with a total of 265 TCs being evaluated. Work in FY 1992 focused on repair and recovery of 92 TCs that were found to be failed or marginal in performance. This task was completed in FY 1992.

- Progress During Reporting Period - No progress was required or planned.

- Planned Work for Subsequent Months - None.

- Problem Areas and Actions Taken - None.

- Milestone Status - This task is considered to be complete.

- March 31, 1992: Complete repair of TC elements, as appropriate, on selected ferrocyanide tanks. Only those TC elements in the waste and occasionally one or more elements in the vapor space were slated for repair. The original milestone was delayed because of other high priority safety work and tank farm entry restrictions. This milestone was completed in September 1992.

\subsubsection{Alternate Monitoring Technologies}

2.1.3.1 Infrared Scanning System. Infrared systems are commercially available from numerous vendors. These systems are sensitive to changes of $\pm 0.28^{\circ} \mathrm{C}$ or less under ideal conditions, and they may prove to be beneficial for mapping surface temperature profiles in the ferrocyanide tanks. Thermal modeling performed on ferrocyanide tank 241-BY-104 suggested that, if hot spots with temperatures of concern are possible, surface temperature differences should be great enough to detect by infrared mapping.

One drawback of an infrared camera is the limited life caused by gamma radiation exposure to the semiconductor components within the scanner. Based upon an average radiation level within the SSTs of 150 Rads per hour, the useful life of an infrared camera may be limited to approximately 100 hours. Therefore, deployment for surface monitoring would have to be done periodically, perhaps monthly or bimonthly, unless tank anomalies dictate otherwise. 
- Progress During Reporting Period. A position paper on the credibility of hot spots and the need for further infrared scanning was completed and issued on April 15, 1993, titled Ferrocyanide Safety Program: Credibility of Drying Out Ferrocyanide Tank Waste by Hot Spots (Dickinson et al. 1993). This paper examines concentration mechanisms and determines the degree of concentration required to produce temperatures high enough to dry the ferrocyanide waste. The paper concludes that such concentrations were incredible. Based upon this report, Westinghouse Hanford Company recommended to the U. S. Department of Energy, Richland Operations Office (DOE-RL) that no further planning be pursued for infrared scans of ferrocyanide tanks for the purpose of detecting hot spots.

- Planned Work for Subsequent Months. The draft report on infrared scans of tank 241-S-110 will be cleared for public distribution.

- Problem Areas and Action Taken. None.

- Milestone Status.

- April 10, 1992: Completed infrared scan of tank 241-S-110. The scan was completed on April 21, 1992, after several delays caused by mechanical and weather-related problems.

- May 29, 1992: Complete a report on the infrared scan of a non-Watch List tank. The report was completed on schedule. DOE comments were incorporated and the document was resubmitted on January 15, 1993.

- December 31, 1992: Incorporate comments received on report of infrared monitoring of non-Watch List tank $241-\mathrm{S}-110$ and issue a revised report. The milestone was missed because other safety issues required immediate action. The report was issued to DOE-RL as a draft document on January 15, 1993. This report will be issued for public availability after receipt of comments from the DOE.

- April 15, 1993: Make a decision on whether infrared scans will be performed in selected ferrocyanide tanks. A publicly available report (Dickinson et al. 1993) concluding that infrared scanning was not required for in situ safe storage was released on schedule.

2.1.3.2 In Situ Tank Moisture Monitoring. Methods for determining moisture concentrations in ferrocyanide waste tanks are being developed using data analysis and available surveillance systems. Two in situ moisture monitoring technologies are currently being pursued, neutron diffusion and NIR. 
Neutron Diffusion. Methods for determination of moisture concentrations in the ferrocyanide waste tanks are being.developing using data analysis and state-of-the-art surveillance systems. Well-logging techniques coupled with computer modeling are being developed and applied to an existing neutron probe to gather information about moisture levels, material interfaces, and other waste characteristics. The existing neutron probe, used routinely to determine liquid levels, is inserted into closed-bottom liquid observation wells (LOWs) to access tank contents.

The development of a new, improved neutron diffusion based detector system is being investigated. This improved technique would primarily be used to determine the axial moisture concentration profile within the ferrocyanide tanks.

Moisture measurement using neutron diffusion is an established technology. The technique uses a neutron source and one or two neutron detectors. The thermal neutrons reaching a detector originate as fast neutrons from the source and are slowed or absorbed by the medium. Because hydrogen atoms are very effective at slowing down neutrons, the detector response is a strong function of the surrounding moisture concentration.

Two methods are generally used to measure moisture concentration around wells using neutron diffusion. The first method, the moisture gauge, has a short source to detector spacing on the order of 0 centimeters $(\mathrm{cm})$ (the source is placed in a ring around the detector) to $6 \mathrm{~cm}$. The response of a moisture gauge is characterized by an increase in detector response with increasing moisture concentration of the surrounding medium. The second method, the neutron log, often has two detectors with longer source to detector spacings $(20 \mathrm{~cm}$ to $50 \mathrm{~cm})$, which exhibit a decreased response to increased moisture concentrations.

The source to detector spacing of the existing Hanford probe can be adjusted with the addition of source extenders. An extender is not currently being used for liquid level detection. Computer modeling of the existing neutron probe system revealed that, in its current configuration, it responds as a moisture gauge. Calculations also revealed that the probe could operate as a neutron log with the addition of a source extender.

- Progress During Reporting Period. In April of 1993, it was discovered that an incorrect setup and calibration procedure had been used for the in-tank neutron probe for the past several years. All scans taken with the in-tank neutron probe during this time period were probably affected by high energy gamma rays because of incorrect probe amplifier and discriminator settings. The probe procedure has been corrected by surveillance technicians. The original calibration data and the data from all special scans performed with the neutron probe before the correction are now considered qualitative.

To obtain a re-calibration of the probe response, measurements in the moisture standards were repeated. Four source-to-detector spacings were used to obtain data for several heights in each moisture standard. The moisture content of the 
sorbent standards is known only to about \pm 2 weight percent. A better probe calibration could be obtained with a more accurate measure of moisture content in the sorbent standards.

Figure 2-3 shows a comparison of measured data with MCNP model calculated results for the neutron probe immersed in water. The reported uncertainty on the measured results are indicative of the statistical error. The MCNF model input source description was adjusted to obtain this level of agreement. The input source spectrum and neutron density were varied until the best possible agreement was obtained.

Figure 2-3. Comparison of Measured Values and MCNP Model Detector Responses

With the Neutron Probe Immersed in Water.

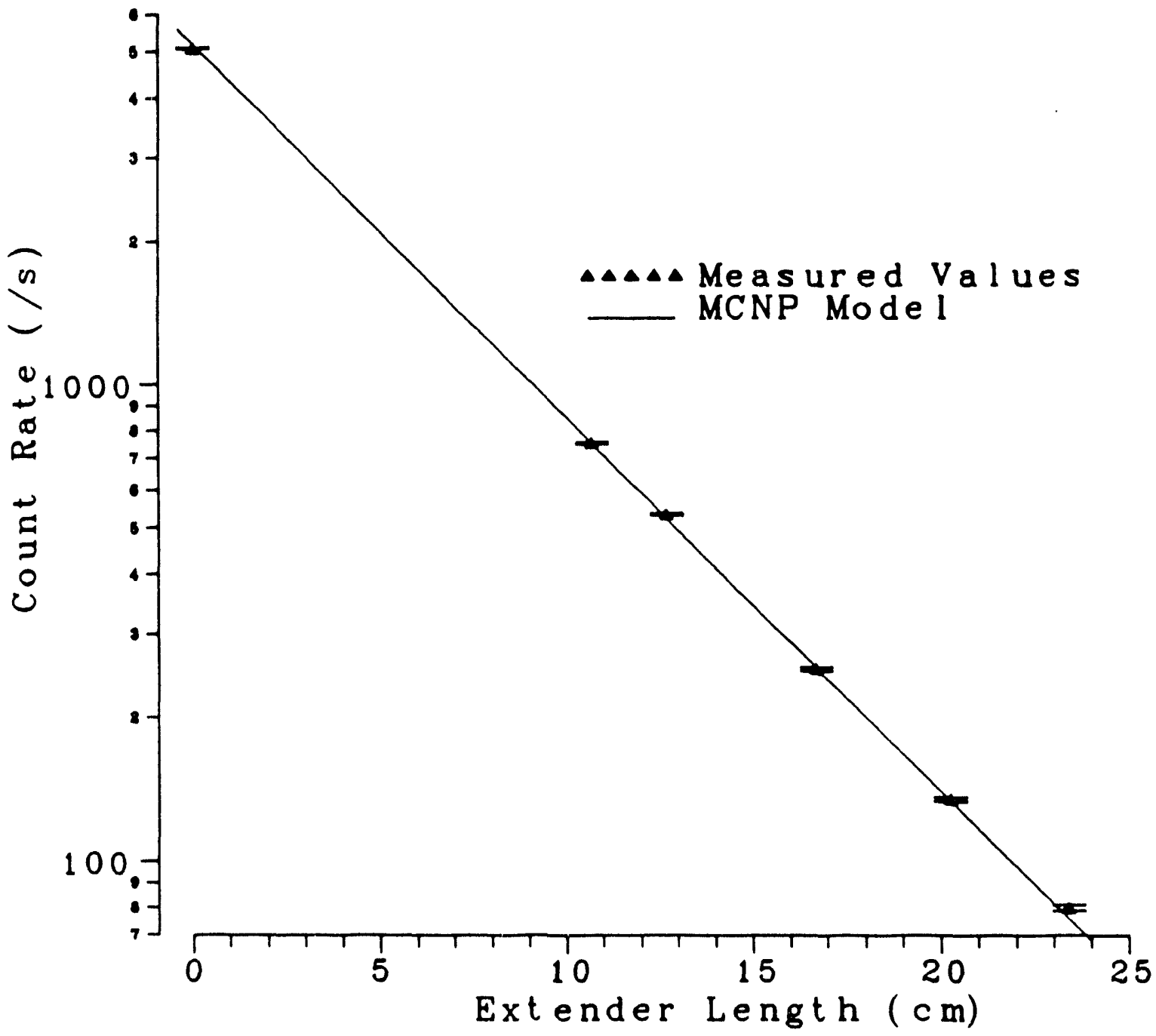


A sample of the fiberglass LOW section used in the moisture standards was submitted to the Process Chemistry Laboratory for elemental analysis. Boron content is of concern since it is a highly efficient neutron absorber. Results of the boron analysis showed that 8.1 weight percent boron oxide $\left(\mathrm{B}_{2} \mathrm{O}_{3}\right)$ was present in the LOW glass and that approximately 29 weight percent of the LOW composite was glass. The LOW manufacturer estimated that the LOW glass contains 8 - 9 weight percent boron oxide and that the glass comprises about 65 weight percent of the composite. Using the laboratory analysis, the weight percent glass value in the model was adjusted.

Figure 2-4 shows a comparison of the measured data and MCNP calculations of the detector response for the neutron probe in an LOW surrounded by water for

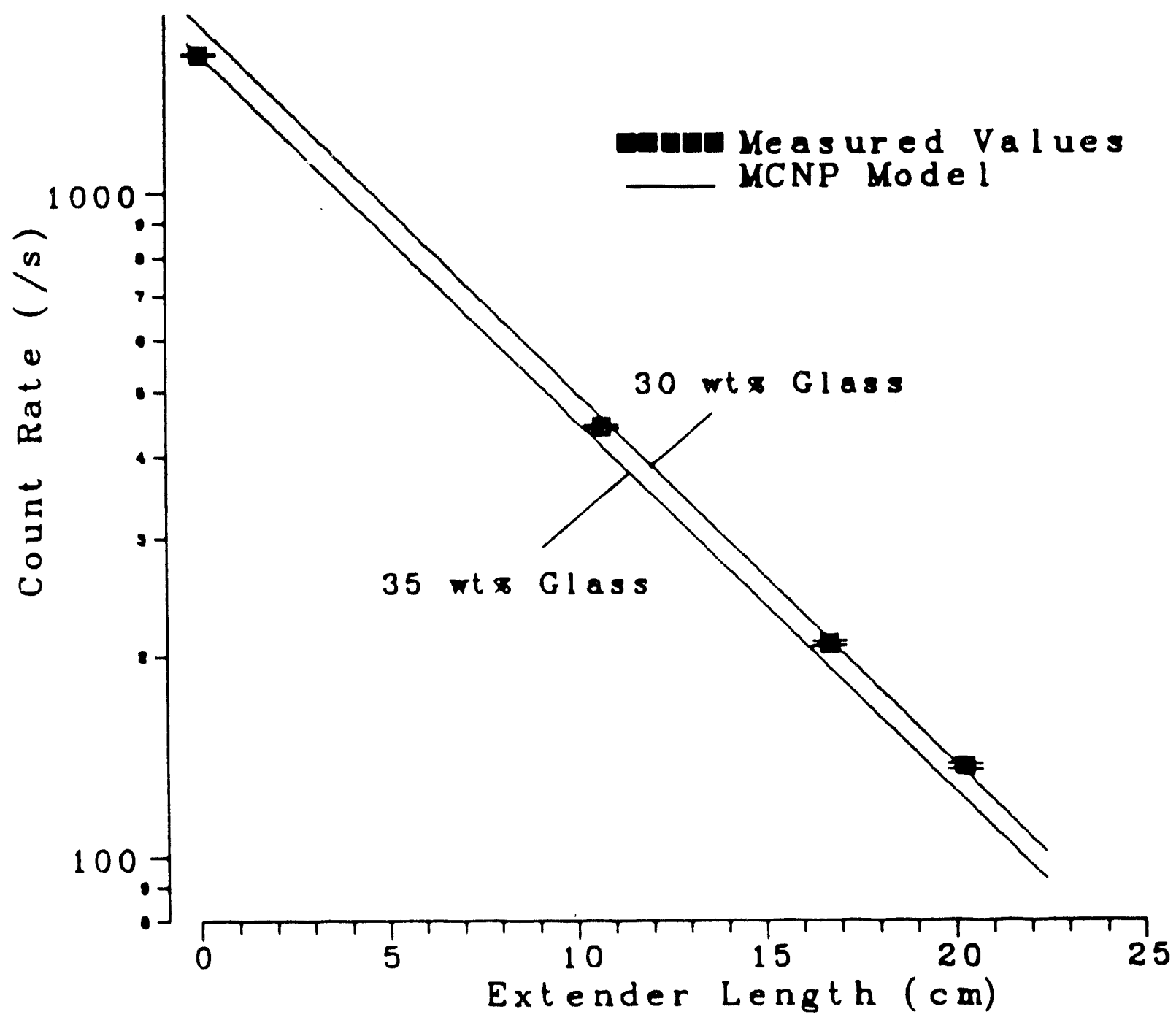


two different assumed weight percent glass in the LOW. Best agreement was obtained between the measured data and the calculations using a 32 weight percent glass value for the composite, a reasonable agreement with the laboratory estimate.

Figure 2-5 shows a comparison of data obtained for several source to detector spacings for the 6,15 , and 30 weight percent moisture concentration standards with corresponding MCNP calculations. The three striped bands represent the uncertainty introduced in the MCNP calculations by uncertainties in the moisture concentrations and in the densities of the three sorbent standards. Because the moisture standard drums are not representative of infinite media at these low moisture concentrations and low densities, the detector response for long extender lengths increases with increasing moisture content.

The most probable explanation for the disagreement seen in Figure 2-5 is that the sorbent, a natural sedimentary opal clay, contains trace amounts of strong neutron absorbers such as chlorine, lithium, or boron. The dashed lines represent revised uncertainty bounds on model calculations if 0.02 weight percent natural boron were present in the sorbent. For the 15 and 30 weight percent cases, the dashed lines represent revised lower bounds. For the 6 weight percent case, the dashed line shows the revised upper uncertainty bound.

The measured density of the sorbent $\left(0.64 \mathrm{~g} / \mathrm{cm}^{3}\right)$ is not within the range specified by the vendor $\left(0.55-0.58 \mathrm{~g} / \mathrm{cm}^{3}\right)$. This may be indicative of differences between the typical chemical composition supplied by the vendor and the true composition. To benchmark the model more accurately, a better defined material with a tightly controlled hydrogen content, density, and neutron absorber content will be required.

Figure 2-6 shows a comparison of measured values and modeled detector responses for two source-to-detector separations. The model results were obtained using the vendor-supplied sorbent chemical composition and the best estimate of moisture content for each standard. Figure 2-7 shows the results of processing the data presented in Figure $2-6$ by dividing both measured and calculated data for no extender cases by data taken with the $20.3 \mathrm{~cm}$ extender. Processing these data leads to the cancellation of some types of systematic errors and to better moisture resolution over a wider range of moisture contents.

Initial development of the computer code Tank Moisture Model (TAMMO) that characterizes neutron scans as a set of interfaces with homogeneous regions between the interfaces was completed. A supporting document will be written that describes the development and possible uses of this data modeling code. The code has been successfully applied to historical neutron scans taken in several of the ferrocyanide tanks. 
WHC-EP-0474-9

Figure 2-5. Comparison of Measured Values and MCNP Modeled Detector Responses With the Neutron Probe Deployed in Moisture Standards.

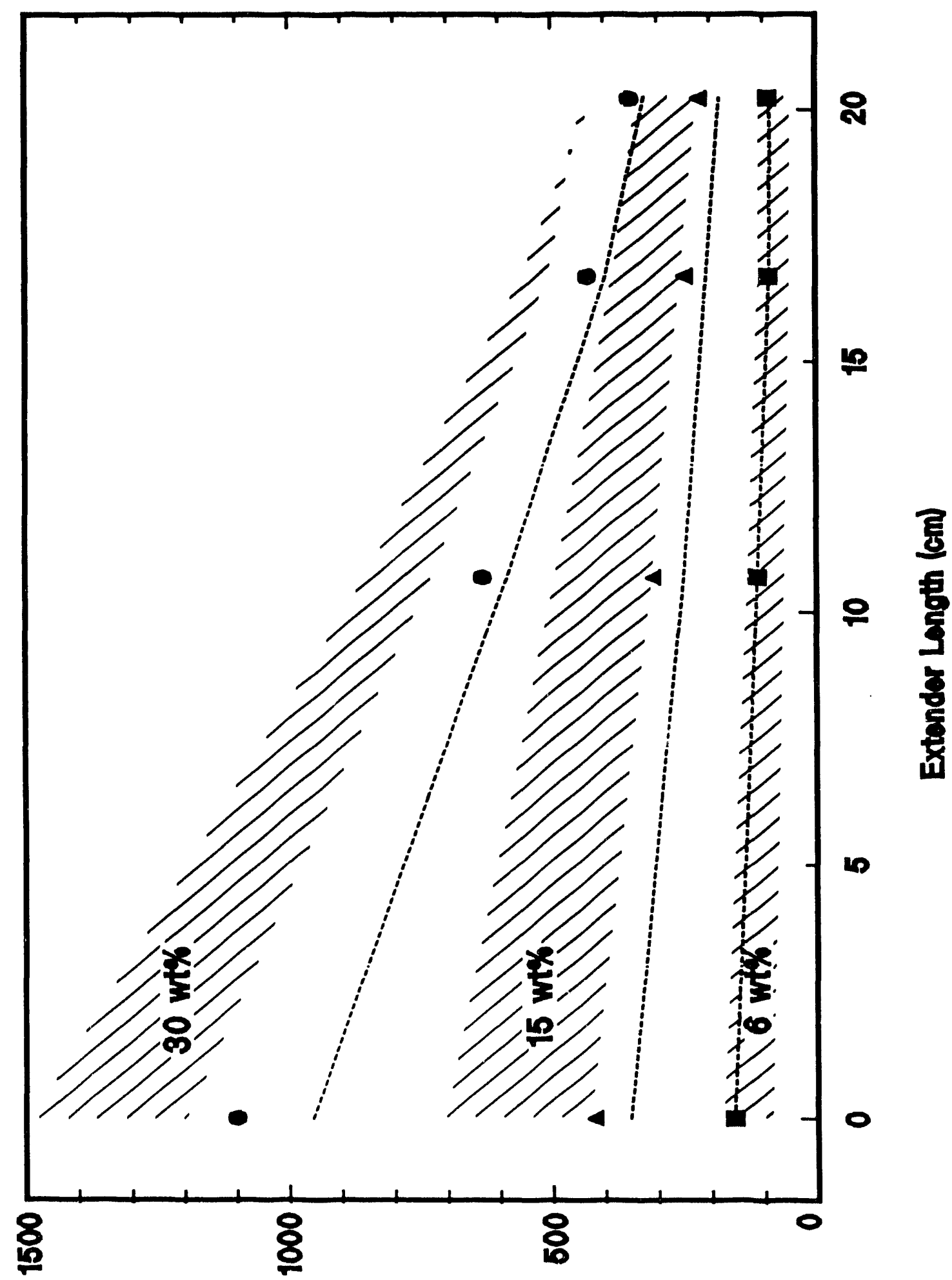

(ष/ ) eqper junos 
Figure 2-6. Comparison of Measured Values and MCNP Modeled Detector Responses for Two Source-to-Detector Separations.

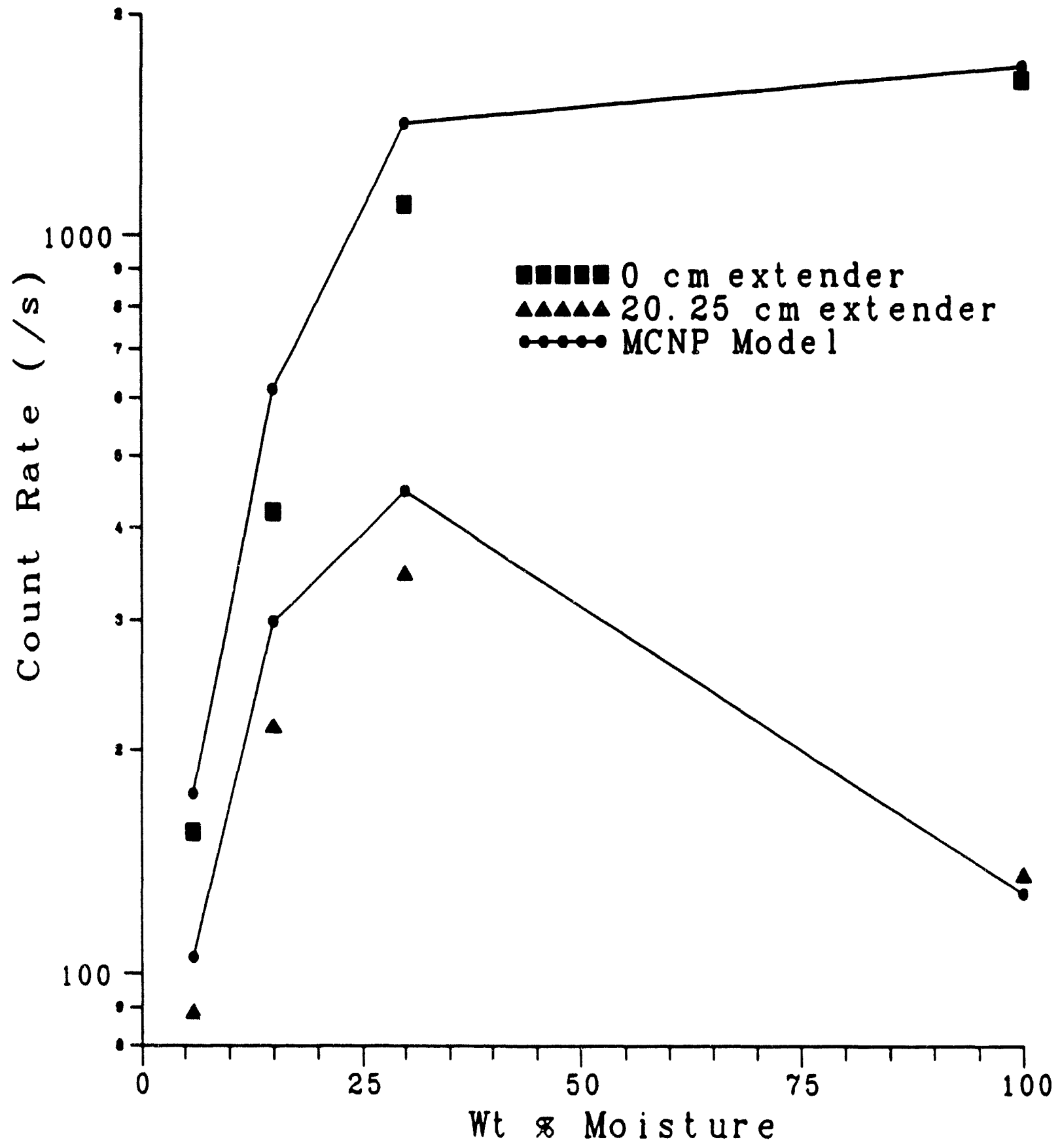


Figure 2-7. Comparison of Measured and MCNP Modeled Response Ratios for Two Source-to-Detector Separations.

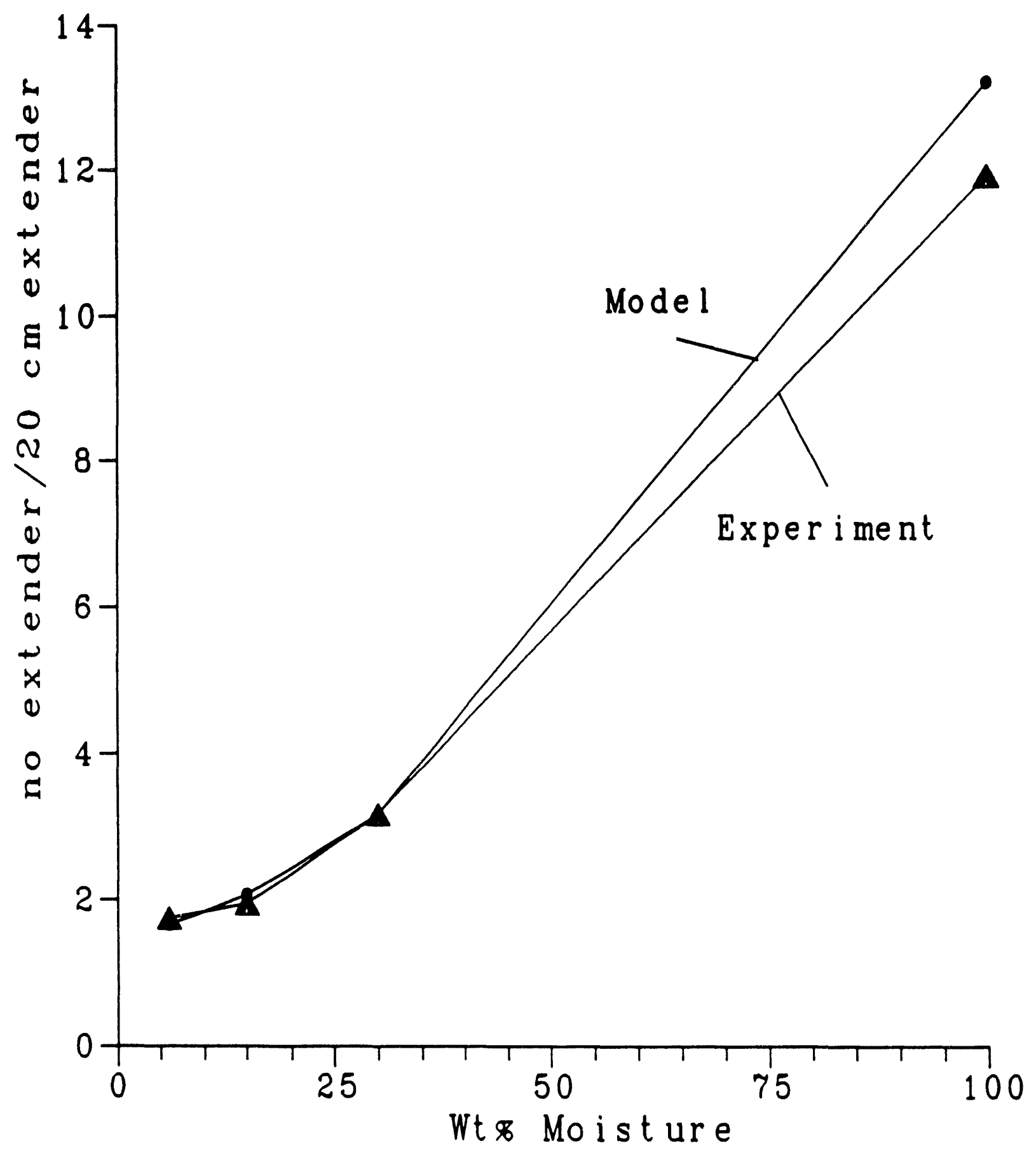


A report reviewing the strengths and limitations of moisture monitoring technologies that could be used to determine moisture concentration in Hanford Site ferrocyanide SSTs was released this quarter, titled Moisture Monitoring of Ferrocyanide Tanks: An Evaluation of Methods and Tools (Meacham et al. 1993). Three alternate technologies were discussed and evaluated in this report: neutron diffusion, near-infrared spectroscopy, and Raman spectroscopy.

All of the moisture monitoring technologies discussed had strengths and limitations. The neutron probe has the potential to determine a vertical moisture profile, but is limited to the location and availability of LOWs. However, experimentation with this system has shown that it has promise as a reliable moisture monitoring system for deployment in the near future.

Optical spectroscopy technologies have inherent optical limitations. Scattering and absorption limits interrogation to the tank waste surface. The nature of the waste surface makes it difficult for laser light to penetrate more than a few millimeters in depth. The systems can also be affected by phenomena that influence the transmission of light, including reflectance and signal strength. However, the potential for added speciation of the waste makes the near-infrared and Raman spectroscopy systems worth investigating.

No single technology may accomplish the level of moisture monitoring desired for the tanks. If moisture data obtained from either LOWs or surface scans are not sufficient, a combination of several technologies may be necessary to achieve a three-dimensional moisture profile of the ferrocyanide waste.

- Planned Work for Subsequent Months. Techniques for measuring the density of materials surrounding the LOW and/or compensating for corresponding changes in the neutron probe response will be explored. This includes testing of a dual detector neutron probe and the possible use of a pulsed neutron source. The use of an epithermal neutron detector to decrease any effects on detector response resulting from the presence of unknown amounts of strong neutron absorbers in the tank waste will also be examined. A simulant more representative of the neutronic properties of ferrocyanide waste will be identified and used to obtain probe data as a final check for the MCNP model.

Neutron test scans will be repeated in the ferrocyanide tanks containing a LOW because original test scans were obtained with an incorrect probe setup and calibration procedure. TAMMO will be applied to characterize any newly obtained ferrocyanide tank neutron scans into interfaces and homogeneous regions. MCNP calculations will be used to estimate the moisture volume percent of these regions and weight percent moisture values will be calculated from estimates of the tank waste density. 
Tank moisture content profiles will be developed from available neutron scans. These moisture profiles will show the MCNP estimated moisture content based upon assumptions about tank composition and density. The moisture profiles may be displayed as a range of moisture content at each height to account for probable uncertainties introduced by material density, composition information, and model calculations. A draft comprehensive proof-of-principle report will be written.

LOWs were inserted through the hard saltcake by sluicing with water. The effect of water sluicing on the annular regions surrounding the LOWs is a concern with neutron probe monitoring. The water may have disturbed significant quantities of waste around the LOWs, resulting in bubbles or void spaces. The annulus surrounding the LOWs may not be representative of the waste matrix, because the density of the waste may have been changed.

However, formation of void spaces around the LOWs during installation should prove not to be a problem for moisture monitoring in the ferrocyanide regions, but density differences may affect the accuracy. The sludge is comprised of small particles and is easily fluidized when mixed with water. Void spaces around the LOWs would be hydrodynamically unstable and the sludge should slump back in around the LOWs.

- Problem Areas and Action Taken. Uncertainties in the actual moisture content and composition of the limited moisture standards has made the initial model benchmarking effort more difficult. Because these standards do not accurately represent the neutron absorption and moderation properties of tank waste, more suitable moisture simulants will be selected to validate the modeling efforts.

Knowledge of the density of materials surrounding the probe is important to the determination of moisture concentration by weight. Possible techniques for either measuring density profiles or correcting for density effects will be investigated. The use of a pulsed neutron source and time-gated epithermal neutron detectors may be helpful in correcting for density and matrix effects in the moisture measurements.

Near Infrared. A potential method for determining in situ moisture concentration in ferrocyanide SSTs is Near Infrared (NIR) Spectroscopy. NIR is an important new analytical technique with a demonstrated capability to perform simultaneous multi-component determinations on irregular solids. Infrared light in this spectrum is absorbed mainly from combinations of carbon-hydrogen, nitrogen-hydrogen, and oxygen-hydrogen bond vibrational motions. bEcause the frequency of a vibration is dependent on the details of the associated chemical bonds, the patterns of absorption provide a unique fingerprint which defines a particular molecule with some degree of certainty. However, compared to the mid-infrared, the absorption bands are much weaker resulting in lower absorption coefficients for NIR. 
The lower absorption coefficients mean that thicker samples can be interrogated which are easier to handle and provide less sampling error. In many cases the log of the inverse of the diffuse reflectance is found to be linear with analyte concentration; this "pseudo Beer's law" behavior makes the data very easy to use. In this region of the spectrum, work can be performed directly with solid samples. There are many cases where the analysis can proceed directly on undisturbed objects in situ.

A contract has been established with CPAC to examine photo-optic techniques that may have potential for in situ moisture monitoring. three spectral regions (visible, NIR, and midinfrared) will be examined as part of a feasibility study (Phase 1). Work will continue in FY 1994 on calibration and optimization (Phase 2).

- Progress during the report period. Preliminary data were received from CPAC on an evaluation of the potential for measuring saltcake surface moisture with infrared techniques. Strong NIR water absorption bands were observed for a 241-BY-104 saltcake simulant material. CPAC is completing calibrated measurements for both the near- and mid-infrared regions.

The Savannah River Site is developing near-infrared systems that would support a surface moisture measurement program. The FY 1994 Technology Development Technical Task Plan guidance included the preparation of a requirements document for a deployed Hanford Site hot cell spectroscopy system. This document was prepared and delivered to SRL for their use in assessing the environmental ruggedness of these systems in accordance with their Technical Test Plan guidance.

- Planned work for Subsequent Months. Work on the Phase 1 study top determine the feasibility of measuring saltcake surface moisture with optical scattering techniques will be completed. A report summarizing the results of Phase 1 will be written, Phase 2 work on calibration optimization will be initiated.

- Problem Areas and Action Taken. None.

- Milestone Status -

- July 31, 1992: Completed fabrication of four neutron source extenders.

- August 29, 1992: Completed preliminary neutron probe scans of surrogate tank 241-B-104 using the modified neutron probe. 
- September 30, 1992: A letter report documenting the current status of Monte Carlo calculations, tank 241-B-104 test scans, and the increased understanding of the neutron probe was completed. The report also included a description of recommended tasks to be performed, including field activities.

- December 1, 1992: Completed neutron probe test scans of tanks 241-BY-101, -104, -105, and -106 using the modified neutron probe.

- March 29, 1993: Limited moisture simulant drums were completed and available for benchmarking efforts.

- April 30, 1993: A report titled Moisture Monitoring of Ferrocyanide Tanks: An Evaluation of Methods and Tools (Meacham et al. 1993) was released.

- June 25, 1993: Complete limited calibration using special simulant-filled drums as standards. A letter report documenting the work completed to meet this milestone was submitted on schedule.

- September 27, 1993: Transmit a comprehensive proof-of-principle report, approved for public release, to DOE-RL. This milestone is on schedule.

- September 30, 1993: Complete CPAC Phase 1 studies and issue a report on the feasibility of measuring surface moisture with NIR spectroscopy.

2.1.3.3 Waste Analysis With Laser Raman Spectroscopy. The objective of this work is to investigate the use of Laser Raman spectroscopy for detecting and quantifying cyanide species (ferrocyanide, ferricyanide, and free cyanide) in Hanford Site high-level waste tanks. Based on successful feasibility work, the goal is to develop in situ or ex situ methods for characterizing these tank wastes. Raman spectroscopy would then be pursued for other anions of interest (such as sulfate, nitrate, nitrite, phosphate, and aluminate) and for organic compounds such as ethylenediaminetetraacetic acid (EDTA) and hydroxyethylenediaminetriacetic acid (HEDTA). The Raman technology will not replace the need for Environmental Protection Agency (EPA) and Tri-Party Agreement (TPA) directed characterization measurement requirements.

The Westinghouse Hanford Company Raman system has been installed in the 222-S Hot Cell Facility. Screening studies using pure and simulant materials in cold tests are being conducted after installation to establish a baseline for the system. Exploratory Raman spectra have been obtained in a 222-S glove box for low level archived tank waste samples from tanks 241-BX-107 and 241-T-111. No interferences or background fluorescence have been encountered to date with the various core segments analyzed. Work is continuing on potential interferences including $\mathrm{pH}(>8)$ and ionic concentration. Tests to establish 
detection limits, accuracy, and precision for ferrocyanide in the presence of other components are underway. Hot cell testing of archived high level tank waste samples is an interim application to direct tank use.

- Progress During Reporting Period. The archived tank waste materials examined with the Raman fiber optic probe were very sticky and adhered to the probe tip. Good Raman spectra data have been obtained in a glove box using a probe wrapped in a plastic sheath. This process would be difficult in the hot cell where all actions have to be accomplished using remote manipulators. A concept for a disposable tip based on the use of a commercially available infrared thermometer with a plastic "throw-away" tip is being evaluated. This disposable cover will prevent cross-contamination of the samples and eliminate the need for probe tip cleaning. This concept will be tested and refined in a cold environment before it is used in the hot cell.

The Westinghouse Hanford Company Raman system has been moved into the 222-S Hot Cell Facility. Preliminary Raman spectra were obtained in a glove box using low level waste material from non-ferrocyanide tanks 241-BX-107 and 241-T-111. Raman data with the near-infrared laser diode showed no evidence of fluorescence. Figure 2-8 shows Raman spectra for the 241-BX-107 tank waste material. The wavelength region shown is the nitrate, phosphate, and sulphate Raman active region. A reference spectra for solid sodium nitrate is included at the bottom. The spectra revealed a strong response in the nitrate/nitrite region since both are present in solution.

Mode hopping instability with the current laser diode has been solved with thermal shielding. Mode hopping is dependent on the laser power setting and temperature. Power and temperature regions can be found where the laser operates in a very stable mode. However, the laser does not lock onto the same wavelength each time it is cold started. Wavelength stable outputs can be obtained after a sufficient warmup period.

The 826 nanometer $(\mathrm{nm})$ diode laser tests with ferro/ferricyanides in solution are producing very low Raman signal levels. A low Raman cross-section and self-absorption within the slurry materials are the suspected causes. In addition, the Raman shift with this near-infrared laser diode places the Raman signals at the upper wavelength edge of optical response of the silicon charged coupled device (CCD) detector. Another limiting factor is the low power available from the laser diode.

To keep the diode laser stable, it must be operated at about half its maximum power level. With the current fiber optic probe about 40 milliwatts ( $\mathrm{mw}$ ) can be delivered to the sample surface through a 6.1 meter (20 foot) long fiber optic filament. This power level represents the energy at the sample surface after all of the optical losses. The system will be modified to use a $200 \mathrm{mw}$ air-cooled 
Figure 2-8. Raman Spectra From Tank 241-BX-107 Waste Tank Core Samples (Cores 40 and 41 ) For the Nitrate-Active Spectral Region.

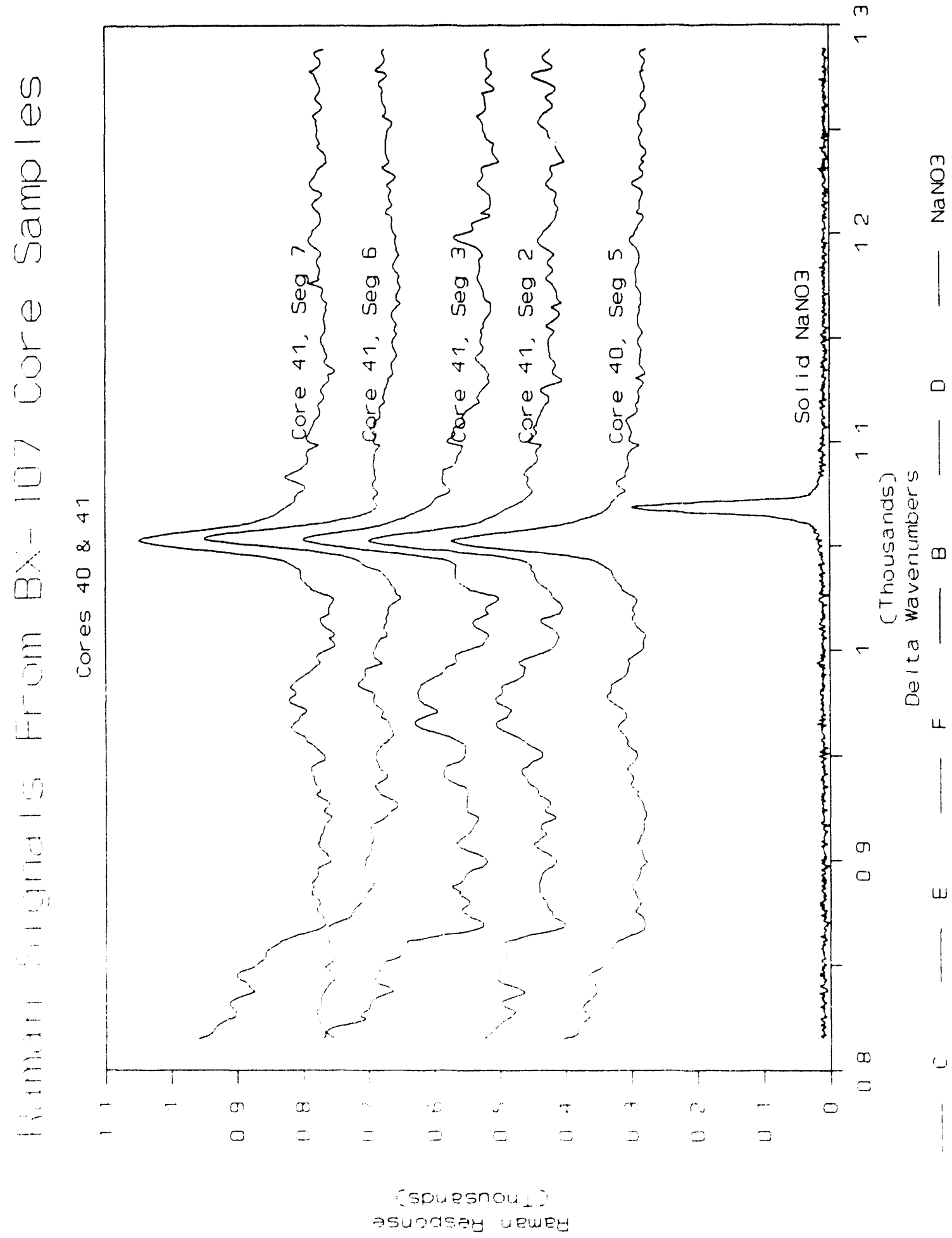


argon ion laser emitting at $514 \mathrm{~nm}$. The $514 \mathrm{~nm}$ line will move the Raman response to a region of higher detector responsivity and will result in a larger signal and greater sensitivity.

The second draft of a hot cell qualification plan was submitted for peer review. The plan was presented to the participants of the FSU June 2-4, 1993 Raman workshop attended by representatives from the Savannah River Laboratory (SRL), Lawrence Livermore National Laboratories (LLNL), LANL, Naval Research Laboratories, DOE-RL, Westinghouse Hanford Company, and FSU.

Procurement actions for all of the new Raman system components, including the laser, CCD detector, and spectrograph have been completed. All components are anticipated to be delivered by the end of July 1993. Other ancillary and support equipment has either been received or ordered and is awaiting delivery.

The FSU Raman feasibility study contract has been renewed. The expanded workscope includes developing a speciation algorithm for ferro/ferricyanides and exploratory spectral work with waste tank organics. FSU will provide archive spectra for Westinghouse Hanford Company to use in hot cells and waste tank Raman campaigns with actual tank waste materials.

- Planned Work For Subsequent Months. Non-radioactive environment benchmark testing, calibration, and spectra archival work with the existing Raman system will continue. Raman spectra from pure compounds, simulants, and actual tank waste samples will be acquired. A disposable probe cover for cold and hot cell use will be developed to eliminate sample cross-contamination and the need for probe cleaning. Work on Raman and other spectroscopy systems at SRL and LLNL will be integrated to provide the best system possible for all involved. A second Raman spectroscopy system will be constructed in the 222-S Laboratory.

- Problem Areas and Actions Taken. Participants of the June 1993 workshop at FSU identified a potential problem with Westinghouse Hanford Company Raman spectra presented at the workshop. Features within the dark spectra indicate that problems exist with the process used to obtain the spectra or that the Raman system has a serious light leak. Westinghouse Hanford Company staff who will be operating the Raman system in the 222-S Laboratory are being sent to FSU for training on Raman system operation and optimization and spectral data processing. The Westinghouse Hanford Company system is identical to one at FSU, so optimization and operational procedures will be directly transferrable. 
- Milestone Status -

- May 1, 1992: Receive initial experimental data from FSU on tests using In Farm and U Plant simulants provided by Westinghouse Hanford Company. Data from FSU on these simulants were received on schedule.

- September 30, 1992: Receive interim report on initial data collection and validation methods for ferrocyanides/ferricyanides. This report was received on October 27, 1992.

- December 31, 1992: Issue final FSU report on initial collection and validation methods with Raman techniques. The report was issued in February 1993, cleared for public release.

- December 31, 1992: Issue an environmental specification document for a hot cell and waste tank deployable Raman system. The specification was issued on January 5, 1993.

- January 31, 1993: Complete renewal of the FSU contract. The FSU contract was renewed on April 3, 1993. Test priorities and materials have been transferred to FSU.

- February 28, 1993: An environmental specification document for a hot cell and waste tank deployable spectroscopy system was issued on February 11, 1993.

- August 31, 1993: Obtain Raman system performance data with actual tank waste materials. Analysis with non-ferrocyanide tank waste have been completed. Waste from two ferrocyanide tanks will be analyzed in August 1993.

- September 15, 1993: Complete demonstration of Raman spectroscopy in a hot cell.

\subsubsection{Hot Spot Thermal Modeling}

The decay of radioactive materials in Hanford Site waste tanks generates heat. A rapid chemical reaction within the ferrocyanide waste might occur if there is a sufficient concentration of ferrocyanide and a high enough temperature present to cause an exothermic excursion and local propagation. There is usually only one or two TC trees in each ferrocyanide tank; see Table A-1 and the trees are not always at the same location. Consequently, there is concern that significant heat generation could exist in these tanks and not be detected. This task models and analyzes the available temperature data from the 
ferrocyanide tanks in order to determine the heat load and temperatures as a function of depth and horizontal location. Sensitivity and parametric analyses are included to determine the magnitude of hot spots that might exist within the waste to cause a propagating reaction to occur.

State-of-the-art validated computer codes are used in the modeling. They are benchmarked with existing data and employ two- and three-dimensional capabilities. Both steady-state and transient models are used. The intent of this work is to determine accurate heat loads for each ferrocyanide tank.

- Progress During Reporting Period. Development of a definitive model for thermal analysis of the ferrocyanide waste storage tanks is being conducted. This model will take into account known data concerning soil moisture content at various locations around the tanks and the accuracy of measured temperatures. It will also include radiant heat transfer to the walls of the tank and the heat load and temperature history of the tanks. It has been found that the tanks are not as close to a steady state condition as previously supposed. The use of a steady-state model produced tank heat loads values conservatively higher than actually exists. The development of this model will be documented in the next tank thermal analysis report.

A report (Dickinson et al. 1993) was publicly released this quarter discussing the probability of a hot spot within the ferrocyanide tanks that could raise the temperature to $120^{\circ} \mathrm{C}$, the approximate boiling point of the waste solution. The report used results from several analyses to describe the concentration factors required for such a hot spot and the mechanisms for forming one. The report concluded that the existence or formation of a hot spot of this magnitude was incredible. The use of infrared scanning to detect a postulated hot spot was also discussed. While infrared scans of the tanks may produce useful information concerning the lateral heat distribution within the tank, the probability of hot spots actually existing is too low to warrant their use.

- Planned Work for Subsequent Months. The development of the heat transfer/heat load model will be completed and heat load analyses of selected tanks will be performed. A report of the analyses will be prepared and issued. Existing analyses will be updated to include the non-steady state correction factors being developed.

Changes will be made to the report titled, Ferrocyanide Safety Program: Credibility of Drying Out Ferrocyanide Waste by Hot Spots (Dickinson et al. 1993) to incorporate comments received from DOE.

- Problem Areas and Action Taken. None. 
- Milestone Status -

July 31, 1992: Determine the heat loads and calculated thermal conductivities of the contents for tanks $241-\mathrm{BY}-105,-106,-108,-110$, -111 , and 241-C-109. The upper and lower bound of these parameters were calculated. A report on this work was delayed to September 30, 1992, to include additional work with thermal conductivities more representative of actual waste. A final report has been delayed to September 1993 so that heat loads of these tanks can be reevaluated with the updated heat transfer/heat load model.

- September 30, 1992: A detailed thermal analysis of tank 241-BY-106 was performed to determine the response of the tank contents to a hot spot of varying intensities. This analysis included both steady-state and transient analyses. A report of this analysis was issued in May 1993 titled, Ferrocyanide Safery Program. Thermal Analysis of Tank 241-BY-106, (McLaren 1993).

April 15, 1993. Perform detailed thermal modeling studies to (1) determine if there is sufficient probability for hot spots to form that would warrant infrared scans of ferrocyanide tanks, and (2) issue a position paper on whether hot spots of concern are credible. The position paper titled, "Ferrocyanide Safety Program: Credibility of Drying Out Ferrocyanide Waste by Hot Spots," (Dickinson et al. 1993) was issued April 15, 1993.

September 17, 1993. Complete thermal hydraulic analyses of four ferrocyanide tanks to determine heat loads and conductivities of the waste contents and issue a report, available to the public, on the results of the analyses.

September 24, 1993. Complete and issue a report, available to the public, of thermal analysis of six ferrocyanide tanks (241-BY-105. $-106,-108,-110,-111$, and $241-\mathrm{C}-109$. 


\subsection{DEFENSE NUCLEAR FACILITIES SAFETY BOARD RECOMMENDATION 90-7.2 (CONTINUOUS TEMPERATURE MONITORING)}

"The temperature sensors referred to above [Recommendation 90-7.1] should have continuous recorded readouts and alarms that would signal at a permanently manned location any abnormally high temperatures and any failed temperature instrumentation."

\subsubsection{Tank Monitoring and Control System}

This task provides continuous monitoring of presently installed (and operable) TCs for the ferrocyanide tanks. New TC trees will be connected to the system shortly after they are installed in each tank, resulting in continuous monitoring of all TC trees in the ferrocyanide tanks. All data are collected automatically at the continuously manned Computer Automated Surveillance System (CASS) Operator Control Station in the 2750E Building, 200 East Area. The monitoring system is independent of the CASS and capable of displaying data to an operator on request. Trend data on selected points are available for display in numeric or graphic form.

The system, which became operational in September 1991, has the capacity to assign alarms for change in the value of any temperature point. Alarms, if they occur, trigger an audible annunciator and are logged immediately to hard copy. An alarm summary display provides a list of the most recent alarms in order of occurrence. Each alarm can be identified by point and time of occurrence. Operator acknowledgement of the alarm will silence the audible annunciator.

Signal conditioning and multiplexing are performed locally at each tank. This eliminates the need to transmit low-level signals to the tank farm boundary and reduces cable runs.

Electronic noise, extension wire corrosion, and thermal gradients are thereby reduced.

Five BY Farm tanks were connected to the system in September 1991, and an additional five in December 1991. These include tanks 241-BY-101, -103, -104, -105, -106, -107, -108, $-110,-111$, and -112 . Tank $241-\mathrm{BY}-105$ has two operating TC trees. Both were connected to the tank monitor and control system (TMACS). In April 1992, tanks 241-TY-101, -103, -104 , and 241-TX-118 were connected to the system and are now operational. Two new TC trees installed in September 1992 in tanks 241-BY-104 and -110 were also connected to TMACS. This makes a total of 14 ferrocyanide tanks (17 TC trees) that are now monitored by TMACS. Temperature readings from the working TCs in these tanks are being recorded continuously.

- Progress During Reporting Period. The design for connection of the four ferrocyanide tanks in the BX Farm was completed. There are currently four ferrocyanide tanks in this farm. Design for connection of new TC trees in 241-BY-101 and 241-TX-118 were completed. New trees installed in 
Tanks 241-BY-111 and -112 were connected to TMACS on schedule. The tanks were previously monitored using a single TC element in the LOW of each tank.

- Planned Work For Subsequent Months. Construction will continue in C, T, and BX Farms. New trees to be installed in Tanks 241-BY-101, 241-TX-118, 241-BX-106, and 241-C-108 will be connected to TMACS.

- Problem Areas and Action Taken. Construction within the farms is presently being delayed because of a shortage in radiation health physics technicians (required for personnel monitoring). In addition, weather conditions are causing delays (entrance into farms is not permitted for winds of 15 miles per hour or greater). The installation of TMACs in C and T Farms may be delayed by up to a month because of these delays.

- Milestone Status -

September 30, 1992: Completed design of the TMACS for C and T Farms.

- July 30, 1993: Complete installation of the TMACS for the four ferrocyanide tanks in C Farm. All 12 tanks in C Farm are being connected to TMACS. This task is behind schedule and will be completed by August 1993.

- August 30, 1993: Complete installation of the TMACS for two ferrocyanide tanks in T Farm (241-T-101 and -107). This task is behind schedule and will be completed in September 1993.

- September 30, 1993: Complete design and installation of the TMACS for the four ferrocyanide tanks in the BX Farm. The milestone remains on schedule.

- September 30, 1993: Complete installation of the TMACS for new TC trees installed during FY 1993.

- September 30, 1994: Incorporate TMACS on new TC trees installed during FY 1994. 


\subsection{DEFENSE NUCLEAR FACILITIES SAFETY BOARD RECOMMENDATION 90-7.3 (COVER GAS MONITORING)}

"Instrumentation should also be installed to monitor the composition of cover gas in the
tanks, to establish if flammable gas is present."

\subsubsection{On-Line Gas Monitoring}

Options for installing a gas monitoring capability on new TC trees has been reviewed and a heated vapor sampling tube has been added to the design of TC trees for ferrocyanide tanks (see Section 2.1.1). However, a definite decision to monitor continuously or just occasionally has not been made. The frequency of gas monitoring and/or the need for continuous monitoring will be determined after a significant number of the ferrocyanide tanks are vapor sampled or if a concern is detected during the sampling program. Evaluation of gas samples secured to date for tanks $241-\mathrm{BY}-104,-110,-111,-112,24:-\mathrm{C}-109,-112$, $241-\mathrm{T}-101,-107,241-\mathrm{BX}-110$, and -111 has indicated no need to continuously monitor for specific gases. The vapor sampling tube design for new thermocouple trees allow vapor space sampling on a continuous or intermittent basis.

\subsubsection{Interim Flammable Gas Monitoring}

The effort to conduct flammable and toxic gas monitoring and analyses in the ferrocyanide tanks is continuing. This effort was transferred to the waste tank Toxic Vapor Program, which is coordinating interim gas monitoring of the ferrocyanide tanks. Plans to develop a cryogenic technique for vapor sample analysis were dropped in favor of methods already validated for this purpose. Therefore, Westinghouse Hanford Company has ceased taking cryogenic samples from the ferrocyanide tanks. Tank vapor spaces are measured for flammability using a commercial combustible gas monitor, and are monitored for toxic gases using an organic vapor monitor and Dräger tubes as required by the safety assessments and work procedures for a particular activity. Development and validation of alternative technologies for vapor space characterization are in progress using Summa canisters and specific absorption tubes.

Because the safety issue associated with ferrocyanide tanks is listed as an Unreviewed Safety Question (USQ), this activity requires DOE Environmental Management Headquarters Program Secretarial Officer (PSO) approval for performing sampling activities within the tanks. Although past sampling conducted by Westinghouse Hanford Company Industrial Hygiene Programs with a combustible gas monitor has indicated no flammable gas content above 6 percent of the lower flammability limit, no qualitative measurements were obtained. The combustible gas monitor is calibrated using pentane gas. Readings are assumed to be for hydrogen gas, which is known to be present from radiolysis of water.

All ferrocyanide tanks are passively ventilated through individual high-efficiency particulate air (HEPA) filters. The "breathing" is dependent on changes in rarometric pressure and 
differences in temperature between the waste tank and the outside air. The pressure change causes a small volume of stagnant air to be replaced with fresh air, which helps control the concentration of chemical vapors inside the tanks.

- Progress During Reporting Period. Vapor space gas sampling was performed in six tanks this quarter: 241-BY-101, -111, -112, 241-BX-106, -110 , and -111 . None of the tanks contained concentrations of flammable gases above the detection limit of the combustible gas monitor. The only compound detected by the Dräger tubes was ammonia at levels from 5 to 80 parts per million.

- Planned Work for Subsequent Months. Flammable gas sampling and selected noxious gas monitoring will be done, as required, to support planned core sampling and thermocouple tree installation.

- Problem Areas and Action Taken. Since the validity of the noxious gas results obtained from the cryogenic gas sampler has been questioned, less sensitive methods will have to be used, such as Dräger tubes and Summa canisters. However, these measurement techniques are adequate for worker safety.

\section{- Milestone Status -}

- September 30, 1992: Complete flammable gas sampling of 241-C-109, 241-BY-110, and 241-T-107 to support push mode core sampling and TC tree installation. Tank 241-C-109 was sampled on August 26, 1992. Tank 241-BY-110 was sampled on September 27, 1992. Tank 241-T-107 was sampled on October 22, 1992.

- September 30, 1993: Complete flammable gas sampling of eight additional ferrocyanide tanks to support push mode core sampling and TC tree installation. To date, six more tanks have been sampled for flammable gas, 241-BX-106, -110, -111, 241-BY-101, -111, and -112 .

March 31, 1994: Complete an evaluation report on selected ferrocyanide tanks to determine which gases, if any, need to be continuously monitored.

September 30, 1994: Complete vapor space sampling of remaining ferrocyanide tanks, as required, to support various field activities, and issue a final report approved for public release. 


\subsubsection{Vapor Space Gas Modeling}

The possibility that localized concentrations or stratification of gases exist in the tanks has been evaluated. Radiolysis of water generates hydrogen, and the interaction of various chemicals in the tanks may also release hydrogen and other gases. Some of these gases may have the potential to be explosive or otherwise hazardous if their concentrations become large enough and are mixed properly with air. This concern is being addressed through the sampling effort described in Section 2.3.2. A modeling effort to determine airflow patterns in the tank vapor space of tank 241-C-109 was conducted to evaluate the amount of mixing and local gas concentrations that could occur. The results of this analysis were used to evaluate the hazards and risks involved during sampling and other intrusive activities within this and other ferrocyanide tanks. This work will help to develop a methodology for performing future vapor space analysis for all ferrocyanide tanks.

This modeling study determined how the composition of the vapor space gases changes with time, and was further used to predict the steady-state equilibrium values for gases of interest. Because the ferrocyanide tanks are all passively ventilated, the vapor space gas composition is strongly dependent upon air flow through the tank, gas generation rates, waste temperature, convective mixing, and heat transfer out of the tank. Two state-of-the-art, validated computer codes (HEATING7 and GOTHIC) were used in the modeling. These codes were validated using existing data and employ three-dimensional capabilities.

An analysis of a second tank was deemed unnecessary because of the well-mixed environment calculated for the first tank. The results of this study have shown that the gases in the tank are well mixed and follow Graham's law for gaseous diffusion. A significant exchange of tank gases with fresh air occurs frequently and the accumulation of flammable gases is precluded. Thermal convection was shown to provide a well-mixed vapor space within the tanks.

- Progress During the Reporting Period. The goals of this tank have been met and the task is completed.

- Planned Work for Subsequent Months. None.

- Problem Areas and Action Taken. None.

- Milestone Status -

- February 8, 1993: Perform an analysis of the airflow patterns in ferrocyanide tank 24l-C-109. Determine the potential to have concentrations of nammable gasses that could lead to hazardous conditions and issue a report on the findings. This report was completed and cleared for public release as WHC-SD-WM-ER-183, Rev 0. (Wood 1993), on schedule. 
April 30, 1993: Complete an analysis, if warranted, of a second tank with greater differential temperatures within the tank and issue a report approved for public release. This activity is not required because analysis of tank 241-C-109 has shown the gases to be well mixed. The gases in all ferrocyanide tanks are believed to be well mixed and exchanged frequently with fresh outside air.

\subsection{DEFENSE NUCLEAR FACILITIES SAFETY BOARD RECOMMENDATION 90-7.4 (FERROCYANIDE WASTE CHARACTERIZATION)}

"The program of sampling the contents of these tanks should be greatly accelerated. The proposed schedule whereby analysis of two core samples from each SST is to be completed by September, 1998 is seriously inadequate in light of the uncertainties as to safety of these tanks. Furthermore, additional samples are required at several radii and at a range of elevations for the tanks containing substantial amounts of ferrocyanide."

\subsubsection{Ferrocyanide Tank Waste Sampling and Characterization}

Characterization of the waste in the ferrocyanide tanks is necessary to (1) guide chemical reaction studies with ferrocyanide waste simulants, (2) provide a basis for estimating the consequences of a runaway ferrocyanide reaction, (3) determine how the ferrocyanide waste can be stored safely in situ until retrieval and disposal actions are completed, and (4) apply the study results to the final ismediation of the waste in these tanks. Knowledge of the concentrations and relative positions of various waste constituents is also important to determine their potential for chemical reactions and the consequences of a potential reaction.

The important reactive materials present in the ferrocyanide tanks are fuel (ferrocyanides, sulfides, and reduced carbon species such as organic complexants), oxidants (nitrates and nitrites), and inerts or diluents (including phosphates, aluminates, sulfates, carbonates, oxides, hydroxides). The location of fission products such as Cesium $137\left({ }^{137} \mathrm{Cs}\right)$ and Strontium $90\left({ }^{90} \mathrm{Sr}\right)$ is important because these products are heat sources that can raise and maintain the temperature of tank contents. Their location is also important because they are potential source terms in postulated radiological releases from an exothermic ferrocyanide reaction. The water content of the waste is very important because the high heat capacity and the heat of vaporization of water make it an effective inerting material. Water content can prevent a sustained combustion or a propagating reaction. Wet ferrocyanide material would require drying before it could react or propagate. Other materials (for example, nickel, copper, lead, and the rare earths) may be important as potential catalysts.

Push-mode core sampling is presently the only viable Hanford Site method for waste tank core sampling until it is demonstrated that rotary-drill core sampling will not produce excessive temperatures in the waste. Seven ferrocyanide tanks suitable for push-mode core sampling were placed on the list of SSTs to be core sampled in FY 1992 and FY 1993. Tank 241-C-112 was core sampled through three risers (two segments per core) in March 
1992, and tank 241-C-109 was core sampled through three risers (one segment per core) in September 1992. Core sampling of tank 241-T-107 was completed in March 1993. Three risers were used to take these four-segment cores (originally it was planned to take only two cores, but sample recovery was poor for several core segments and an additional core was requested.

Development and design work has been completed that demonstrates rotary-drill core sampling of "harder" waste can be done without producing unacceptably high bit temperatures Acceptance testing has been coupled and the system is ready for operability tests.

Progress During the Reporting Period. The analytical data packages for the three core samples from tank 241-C-109 were released by the Hanford Analytical Services Management organization. A data interpretation report is being prepared. The major conclusion of the report is that the waste in tank 241-C-109, as found for tank 241-C-112 waste, cannot support a propagating reaction, even when dry. The report will be ready for public release by the end of next quarter. Highlights of the data are given below and Table 2-1 summarizes the major analytes found in the samples.

As reported previously, three one-segment cores $(47,48$, and 49) were obtained from tank 241-C-109 and analyzed. Poor sample recovery (approximately 35 percent) was obtained for core 48 . Cores 47 and 49 were divided into three subsegments and composites made. Core 48 contained material for only two subsegments; therefore, conclusions based on analyses of this core sample should be moderated. The upper subsegments of cores 47 and 49 contained $18-21$ weight percent moisture, the middle subsegments contained 28 - 40 weight percent moisture, and the bottom subsegments contained 39 - 40 weight percent moisture.

None of the core 47 and 49 subsegments or composites exhibited exotherms during differential scanning calorimetry (DSC) analyses; however, all contained a large endotherm in the temperature range where a ferrocyanide exotherm would be expected. The Core 48 sample was analyzed as having 51 - 53 weight percent water and showed a small exotherm ( -26 to -28 Joules/gram) in the temperature range where a ferrocyanide exotherm peak would be expected. The tank 241-C-109 material appears to be less reactive than tank 241-C-112 waste, even though it contains less moisture.

Table 2-1 shows that aluminum is present at higher concentrations than sodium for most of the subsegments and core composites of cores 47 and 49 . This observation is attributed to a high aluminum content in the feed stream of the scavenged waste. The feed for the last two batches of waste scavenged and settled in tank 241-C-109 was from the evaporator that concentrated bismuth phosphate process first decontamination cycle waste. First cycle waste also contained aluminum decladding waste. 
Table 2-1. Major Analytes for Tank 241-C-109, Cores 47, 48, and 49.

\begin{tabular}{|c|c|c|c|c|c|c|c|c|c|}
\hline SAMPLE & $\begin{array}{l}\text { ALUNINLIM } \\
(\mathrm{ppm})\end{array}$ & $\begin{array}{c}\text { CALCIUM } \\
(\mathrm{ppm})\end{array}$ & $\begin{array}{l}\text { IRON } \\
(\mathrm{ppm})\end{array}$ & $\begin{array}{l}\text { SODIUM } \\
\text { (ppm) }\end{array}$ & $\begin{array}{l}\text { NICKEL' } \\
(p p m)\end{array}$ & $\begin{array}{c}\text { PHOSPHOROUS } \\
(p \mathrm{pm})\end{array}$ & $\begin{array}{l}\text { URANIUM } \\
\text { (ppm) }\end{array}$ & $\begin{array}{l}\text { NITRITE } \\
\text { (ppm) }\end{array}$ & $\begin{array}{l}\text { NITRATE } \\
\text { (ppm) }\end{array}$ \\
\hline CORE $47.1 \mathrm{~B}$ & 131,600 & 10,400 & 63,400 & 51.100 & 19.400 & 7,600 & 11,800 & 27,900 & 27,600 \\
\hline $1 \mathrm{C}$ & 120,300 & 18.000 & 20.900 & 63.100 & 22.700 & 12.500 & 6,100 & 37,000 & 36,000 \\
\hline $1 \mathrm{D}$ & 32.000 & 28.000 & 15.300 & 102,600 & 25.600 & 30,100 & 5,800 & 40,000 & 38,500 \\
\hline COMPOSITE & $116.8(x)$ & 24.700 & 21.800 & 87.200 & 31,900 & 19,900 & 9,200 & 39,000 & 37,000 \\
\hline CORE 48.10 & 7.300 & 29.300 & $20.0 \times 0$ & 115.800 & 44.200 & 23,300 & 16,700 & 51,000 & 56,000 \\
\hline 10 & 9.800 & 16.800 & 21.000 & 102.000 & 24.0000 & 20,900 & 14,400 & 50,000 & 53,500 \\
\hline COMPOSITE & 8.600 & 17.700 & 22.200 & 100.000 & 33,000 & 20,200 & 24,700 & 45,000 & 48,000 \\
\hline CORE 49. 1B & 185.300 & 4.300 & 15.600 & 43,000 & 10,800 & 4,100 & 7,900 & 26,500 & 25,700 \\
\hline 10 & 95.800 & 18.600 & 4.600 & 62.900 & 31,900 & 11,500 & 1,300 & 44,000 & 42,000 \\
\hline iD & $70.9(x)$ & 22.500 & 15.400 & 91.400 & 30,700 & 20.400 & 12,400 & 45,000 & 43,000 \\
\hline COMAPOSITE & 126.000 & 14.900 & 9,100 & 76.500 & 22,900 & 14,600 & 4,700 & 39,000 & 36,000 \\
\hline D. Liquid: & 157 & 209 & 1.675 & 96,900 & 344 & 4.200 & $<\mathrm{DL}^{3}$ & 71,000 & 72,000 \\
\hline
\end{tabular}

Nichel concentrations are biased high. Values were derived from inductively coupled plasma fusion analysis performed in a nickel crucible. However. in each case the blank value was an order of magnitude less than the measurement.

:Draintiple liquid sample made by combining liquids obtained from Cores 47 and 49 (one-third of liquid was from Core 47 ; two-thirds was from Core 49).

'DL $=$ Detection himt 
A possible explanation for the large endotherms observed in cores 47 and 49 is the dehydration of aluminum hydroxide to alumina and water. This phenomenon was also observed in non-ferrocyanide tank 241-U-110 (Brown and Jensen 1993); however, this hypothesis for 241-C-109 requires further investigation.

A consistent distribution of ${ }^{90} \mathrm{Sr}$ was found between the 241-C-109 core samples. Stratification of ${ }^{90} \mathrm{Sr}$ and ${ }^{137} \mathrm{Cs}$ in the tank corresponds well with known process history. Waste transfers in and out of the tank do not appear to have dramatically displaced the settled waste. Core 48 particle size distribution and analyte concentrations correspond much better with the material from 241-C-112, core 34, than with the other cores from 241-C-109.

Analytical analysis of the three four-segment cores taken from tank 241-T-107 is continuing. Core sampling was completed March 15, 1993, and hot cell analyses of the samples started shortly thereafter.

Acceptance testing for the rotary-drill core sampler has been completed. The operability test procedures are scheduled to begin next quarter.

- Planned Work For Subsequent Months. The data interpretation report for tank 241-C-109 core samples will be completed and issued. Analyses of tank 241-T-107 core samples will continue and a data interpretation report will be prepared. Push-mode core samples will be taken from tanks 241-C-111 and -108 .

Core sampling of ferrocyanide tanks with saltcake has been deferred until the rotary-mode core sample truck is available for field use. However, possible push-mode core sampling of tank 241-BY-104 will be evaluated. This effort was started because installation of the new thermocouple tree into this tank in September 1992 showed the waste to be softer than expected. Evaluation is scheduled for completion before August 30, 1993. Push-mode core sampling, if feasible, could still be completed in FY 1993.

- Problem Areas and Actions Taken. Core sample recovery continues to be a problem for push-mode core sampling of tanks. Although the sampler valve assembly was changed to incorporate a spring-loaded mechanism to close the sampler tightly, one of the three tank 241-C-109 core sample segments still had poor recovery. A third core was taken from tank 241-T-107 because one of the first two cores had poor recovery. Poor sample recovery was also experienced in push-mode core sampling of non-ferrocyanide tanks 241-T-105 and -102. Core sampling has been suspended by Westinghouse Hanford Company while the core recovery issue is being resolved. Recovery actions 
include the formation of a core sampling restart team, consultation with an external panel of experts, restricted in-tank testing, and controlled laboratory equipment testing.

\section{- Milestone Status -}

- $\quad$ August 30, 1992: Obtain three full-length push-mode core samples from tank 241-C-109. Core sampling was completed on September 7, 1992.

- September 30, 1992: Obtain two full-length push-mode core samples from tank 241-T-107. One core sample was secured in November 1992; however, core sampling was suspended at that time until findings from a DOE-RL audit were satisfactorily resolved. Sampling resumed on February 17, 1993 and was completed on March 15, 1993. A third core sample was taken because one of the original cores showed poor sample recovery.

- March 31, 1993: Complete interpretation of ferrocyanide tank 241-C-112 analytical data and issue a report cleared for public release. This data interpretation report also addressed another milestone and the issue date was deferred to April 30, 1993 to accommodate another required review for the document. That document issue date was met and the document was distributed. However, DOE-RL supplied further input regarding the tank characterization report's content and format and a revision incorporating these elements is being prepared.

April 30, 1993: Complete interpretation of ferrocyanide tank 241-BY-104 auger surface sample analytical data and issue a report cleared for public release. The interpretation report was issued on May 10, 1993 after incorporating changes requested by DOE-RL.

July 31, 1993: Complete interpretation of ferrocyanide tank 241-C-109 analytical data and issue a report cleared for public release. This milestone has been deferred to August 31,1993 , because the validated laboratory analyses data packages were not received until May 14 , 1993. The 241-C-109 report will incorporate elements of the DOE-RL comments received on the $241-\mathrm{C}-112$ data interpretation report.

September 30, 1993: Complete interpretation of ferrocyanide tank 241-T-107 analytical data and issue a report that is cleared for public release. This milestone has been deferred to January 12, 1994 because the core sample completion was delayed approximately four months. There laboratory data analysis report will therefore be late as well. 
- September 30, 1993: Obtain two full-length push-mode core samples from four additional ferrocyanide tanks in FY 1993. The following order for sampling in the tanks is planned: $241-\mathrm{C}-111,-\mathrm{C}-108$, $-\mathrm{T}-101$, and $-\mathrm{BX}-102$ or $-\mathrm{BX}-106$. If feasible, sampling of tank 241-BY-104 may be substituted for one of the last three tanks listed.

- September 30, 1994: Secure core samples from four ferrocyanide tanks (tanks 241-BY-104, -110, -107, and -105).

- September 30, 1995: Obtain core samples from four ferrocyanide tanks (tanks 241-BY-103, -112, -TY-103, and -BY-106).

- September 30, 1996: Obtain core samples from four ferrocyanide tanks (tanks 241-BY-101, -TY-101, -104, and -BY-110).

- September 30, 1997: Obtain core samples from the remaining five ferrocyanide tanks (tanks 241-BX-106, -111, -BY-111, -TX-118, and $-B Y-108)$.

\subsubsection{Simulated Ferrocyanide Waste Preparation and Characterization}

Ferrocyanide waste precipitates are being prepared and analyzed to determine the composition, physical properties, and chemical reaction properties of simulants that represent ferrocyanide waste stored in SSTs. The analytical results from these simulants, along with analyses of actual tank waste samples, waste tank monitoring, and waste modeling provide information to characterize and resolve safety concerns associated with the ferrocyanide tanks. The results will provide technical bases for (1) measures to be taken, (2) closure of the ferrocyanide USQ, and (3) resolution of the ferrocyanide safety issue and (4) eventual disposal of the waste.

Five waste simulants (without radioactive species) are being used to represent the variety of waste produced in the mid-1950s and stored in SSTs. The wastes produced at the Hanford Site's U Plant are represented by U Plant 1 and U Plant 2 test mixtures. The U Plant 1 waste simulant represents 41 of 59 batches and the U Plant 2 simulant represents 9 of 59 batches of U Plant waste. Each U Plant batch was about 2,300,000 liters (L). The other nine batches of $U$ Plant waste are expected to have a ferrocyanide concentration between that of U Plant 1 and U Plant 2. A test mixture representing these batches will not be prepared and tested.

The in-farm flowsheet waste (in four C Farm tanks) is represented by In Farm 1 and In Farm 2 test mixtures. The In Farm 1 test mixture is representative of one batch (expected to have the greatest ferrocyanide concentration) of 29-in farm batches processed in the 1950s. In Farm 2 is representative of 11 intermediate ferrocyanide concentration batches of the 29-in farm batches. An average size in farm batch was approximately 1,500,000 L. It 
should also be noted that six of these 29 scavenging batches did not contain any ferrocyanide, but did contain sodium sulfide to enhance precipitation of ${ }^{60} \mathrm{Co}$ already used.

A T Plant simulant was prepared for testing to represent the six $\mathrm{T}$ Plant batches produced. An average T Plant batch was $2,098,000 \mathrm{~L}$. The T Plant ferrocyanide sludge is stored in three TY Farm tanks.

Three main adjustments from the actual processes used in the 1950s were made in the laboratory scavenging preparation method to provide waste simulants representative of ferrocyanide sludges. These changes were as follows: (1) the solution concentrations were adjusted to include nitrite at a 1:3 mole ratio of nitrite/nitrate, to account for nitrite buildup over time in the wastes by radiolysis of nitrate, (2) the waste simulants prepared or being prepared for characterization do not or will not contain radioactive isotopes present in actual waste because of the difficulty in working with radioactive materials, and (3) the settled waste simulants from the laboratory scavenging process were centrifuged at a force of $2,000 \mathrm{~g}$ to mimic an equivalent 30 gravity year settling period.

One of the main parameters of interest for the ferrocyanide sludges is water content. Tests with in farm simulant have demonstrated that propagation properties are strongly affected by water content. Propagation tests were conducted on vacuum dried simulants for which the water content was assumed to be zero. Water measurement tests were conducted this quarter to determine the actual water content (including chemically bound water) of simulants dried by three different drying methods.

- Progress During Reporting Period. T Plant simulant was prepared and shipped to various laboratories for characterization and reactivity testing. The simulant formed three distinct layers after centrifuging to mimic 30 years of settling. The simulant amounted to a 0.038 volume fraction of feed solution and had an average specific gravity of 1.3. The layers consisted of a bottom white or tan layer of about 9 volume percent, a middle brown layer of about 83 volume percent, and a top grey layer of about 8 volume percent.

The simulants were divided into two fractions, a bottom white or tan layer and a mixed middle and top layer. These two fractions were sent to the analytical labs for chemical analysis and to Fauske and Associates, Inc. (FAI) for adiabatic calorimetry testing.

Initial thermal and gas release analyses at Westinghouse Hanford Company indicated that the bottom layer did not exhibit exothermic activity and gases were not released other than water when heated up to $500{ }^{\circ} \mathrm{C}$. The middle and top fractions exhibited very similar exothermic activity (at $360^{\circ} \mathrm{C}$ ) and gas release behavior (see Figures 2-9 and 2-10). Gases released included nitric oxide and carbon dioxide at approximately $360{ }^{\circ} \mathrm{C}$ for both the top and middle fractions. 
Three drying methods were evaluated this quarter using In Farm 2 top fraction simulant. The drying methods were: (1) heating to $120^{\circ} \mathrm{C}$ in air at atmospheric pressure for 18 hours, (2) heating to $105^{\circ} \mathrm{C}$ in air at atmospheric pressure for 24 hours, and (3) heating to $60^{\circ} \mathrm{C}$ under vacuum at 35 millimeters $(\mathrm{mm})$ mercury $(\mathrm{Hg})$ absolute for 24 hours. Water content of the dried simulants was determined by heating to $320^{\circ} \mathrm{C}$ while simultaneously recording weight loss and analyzing the gases released.

Results of the drying analyses indicated a four sample average of $4.4 \pm 0.1$, above $4.3 \pm 0.6$, and $7.2 \pm 2.1$ weight percent residual water content for each of the listed drying methods, respectively. Tightly bound water (water released between $170^{\circ} \mathrm{C}$ and $280^{\circ} \mathrm{C}$ ) content of the $120^{\circ} \mathrm{C}$ dried material ( $3.4 \pm 0.2$ weight percent) was slightly higher than for the two other methods $(2.6 \pm 0.3$ weight percent). The weakly-bound water varied from an average of 4.6 weight percent for the $60^{\circ} \mathrm{C}$ vacuum dried simulant, to 1.0 weight percent for the $120^{\circ} \mathrm{C}$ dried simulant.

The In Farm 1 bottom fraction material dried at FAI by heating to $60^{\circ} \mathrm{C}$ for 24 hours at $35 \mathrm{~mm} \mathrm{Hg}$ absolute pressure had an average tightly bound water content of $3.8 \pm 0.1$ weight percent and a weakly bound water content of $2.0 \pm 0.1$ weight percent. The In Farm 1 top traction material dried at FAI by heating to $60^{\circ} \mathrm{C}$ for 24 hours at $35 \mathrm{~mm} \mathrm{Hg}$ absolute pressure had an average tightly bound water content of $3.6 \pm 0.4$ weight percent and a weakly bound water content of $1.8 \pm 0.3$ weight percent. It was noted that for the three types of vacuum dried simulants, the tightly bound water content was about 2.5 to 5.5 moles of water per mole of ferrocyanide.

Residual water content values impact the application of the previous propagation results on vacuum dried simulant tests that were assumed to have had a zero water content. For example, it must be noted that for propagation tests conducted on the In Farm 1 bottom fraction simulant at an initial temperature of $60^{\circ} \mathrm{C}$, the water content was about 5.8 weight percent rather than the assumed zero. Results of energy release tests would only be slightly impacted, because the external heat used would have driven off all of the weakly bound water and most of the tightly bound water before the point of reaction (about $245^{\circ} \mathrm{C}$ ).

Drainage tests are being conducted to determine the amount of moisture retained when water is allowed to drain from ferrocyanide waste simulants. Modeling and experimental data will be used to approximate moisture retention in the ferrocyanide SSTs in the event of a tank leak or saltwell pumping of liquids for tank stabilization. A free flowing liquid drainage test using In Farm 2 top fraction simulant at one atmosphere pressure has been continuing for about 12 months. The test consists of a $10.2 \mathrm{~cm}$ (4 inch) diameter column 
Figure 2-9. Thermal and Gas Release Analyses for T Plant Middle Fraction Simulant.
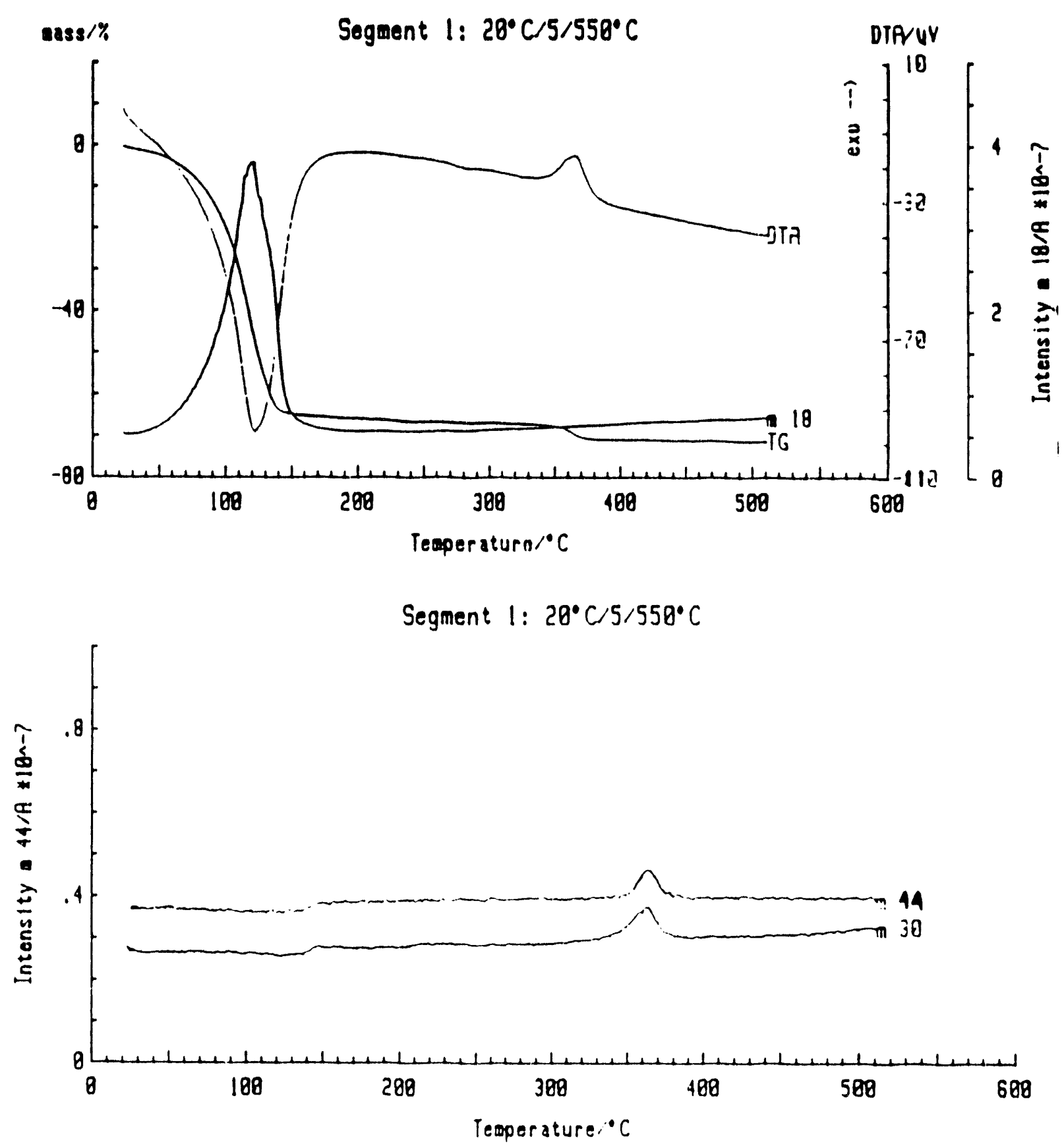
Figure 2-10. Thermal and Gas Release Analyses for $\mathrm{T}$ Plant Top Fraction Simulant.
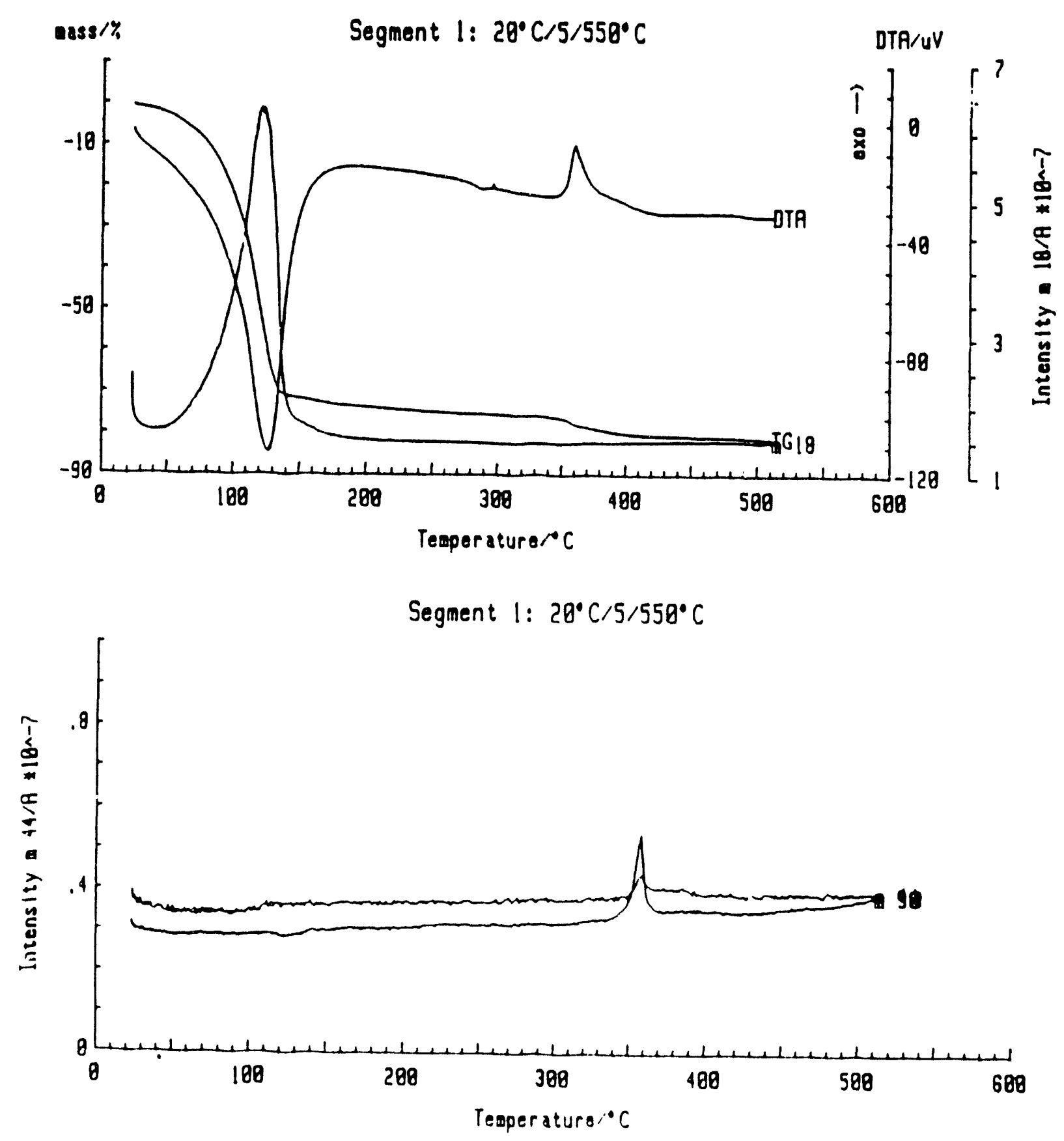
filled with simulant at an initial height of $20.3 \mathrm{~cm}$ (8 inches). The initial water content of the simulant was 53 weight percent. Calculations from the measured liquid drained to date indicate that the remaining material has a water content of about 49 weight percent. Liquid is continuing to drain very slowly from this material with no apparent termination anticipated in the near future. Some consolidation of the sludge has been observed as seen by slumping of the simulant.

Free flowing centrifugation tests have been conducted at 20 gravities centrifugal force with fritted porus media (30 micrometer sized openings). Preliminary results indicate the sludge retains 49 weight percent moisture. An additional test is planned at 10 gravities to determine a water retention content at this force. This should allow extrapolation to a final water content that is well above the minimum water content required to prevent propagation of the most concentrated ferrocyanide simulant.

- Planned Work for Subsequent Months. A concentrated ferrocyanide waste simulant based on tank waste sample characterization analyses will be prepared and tested. Simulant drainage tests will continue and a report will be prepared for public release.

- Problem Areas and Actions Taken. None

- Milestone Status -

- December 31, 1992: Issued draft report on the flowsheet waste simulant compositions and ferrocyanide species characterization.

- January 30, 1993: Issued final report (Jeppson and Wang 1993) on the flowsheet waste simulant compositions and ferrocyanide species characterization.

- July 30, 1993: Issue reports on dryout and drainage tests.

\subsubsection{Position Paper on Safety of Ferrocyanide Tanks}

In June 1991, the Tanks Advisory Panel (TAP) requested that Westinghouse Hanford Company prepare a position paper on the state of knowledge at that point in time concerning the ferrocyanide safety issue. The paper was to document what was known about continued safe storage of the ferrocyanide waste in the high-level waste tanks at the Hanford Site. The primary purpose of the report was to assess if it was possible for a significant exothermic chemical reaction to occur in the tanks under existing conditions and whether the reaction could reach a runaway state in which radioactive aerosols would be expelled from the tank, as postulated in the General Accounting Office report (Peach 1990). The safety of continued 
storage is of interest for all long-term storage, mitigation, remediation, or treatment options because significant storage time would still accrue before options could be selected and completed that would modify the waste form and render it safe.

The ferrocyanide position paper and planned revisions represent snapshots in time of (1) what is known about ferrocyanide wastes stored in underground tanks at the Hanford Site, (2) what this information means in terms of storage safety, (3) what key uncertainties exist, and (4) what must be done to close the ferrocyanide USQ and resolve the safety issue. The position paper is an overview document with technical backup provided by the ferrocyanide hazards assessment document (Grigsby et al. 1992) or, in the future, by the technical basis document to be prepared to resolve the Ferrocyanide safety issue (see Sections 2.4 .4 and 2.4.6).

A draft position paper was issued November 27, 1991 for DOE and TAP review. Comments were received by May 1992 and the document was revised and cleared for public release as WHC-EP-0531, Rev. 1 (Postma et al. 1992) on July 24, 1992. Updates of the position paper will be issued as significant new information becomes available and as results of core sample analyses are reported.

- Planned Work for Subsequent Months. Work on the next update of ferrocyanide position paper will commence in FY 1994. The report will be issued to DOE for review and cleared for public release by September 30, 1994.

- Problem Areas and Action Taken. None

- Milestone Status -

- November 27, 1991: Issue position paper on current understanding of ferrocyanide safety issue. This was completed on schedule.

March 15, 1992: Issue position paper as a document cleared for public release. This was delayed because review comments were not received on the requested schedule. The deadline was revised to July 1992. The position paper was released as a public document on July 24 , 1992.

December 31, 1993: Issue a ferrocyanide position document, approved for public release, that updates the current understanding of the ferrocyanide safety issue. This will be a revision of WHC-EP-0531, Rev. 1. (Postma et al. 1992). The release of this document has been deferred to September 1994 in order to concentrate on closure of the ferrocyanide USQ in January 1994. 


\subsubsection{Ferrocyanide Waste Tanks Hazards Assessment}

The scope of the ferrocyanide hazards assessment task was to provide a technical assessment and periodic updates of the ferrocyanide waste tank safety concerns and progress towards resolution of the ferrocyanide safety issue. These assessments are based on information as it becomes available from the Ferrocyanide Safety Program. Contributions are included from FAI, LANL, Pacific Northwest Laboratories (PNL), Westinghouse Hanford Company, and other sources.

A predecisional interim report assessing the ferrocyanide waste tank hazards was issued on December 3, 1991 for review and comment by TAP, DOE-HQ, and DOE-RL. Comments were incorporated into a new revision, approved for public release, and the document was issued on July 24, 1992 as WHC-SD-WM-RPT-032, Rev. 1 (Grigsby et al. 199?). The report reviews the understanding of the ferrocyanide hazard at the time the report was prepared. It presents an integrated evaluation and interpretation of historical data and recently acquired information. These interim reports will continue to be revised and expanded as additional information becomes available through ongoing work.

Several review comments received on the draft document could not be resolved in the July 1992 release because sufficient information was not available at the time the report was written. These comments were to be incorporated into the next revision of the document.

- Progress During the Reporting Period. The effort to update the ferrocyanide hazards assessment document was redirected this quarter towards developing a safety criteria document close the Ferrocyanide USQ by January 1994. Since the USQ closure milestone was advanced by seven months and major efforts are directed towards this task, a decision was made to defer the next update. This safety criteria document will provide the technical basis for closure of the Ferrocyanide USQ.

- Planned Work For Subsequent Months. Preparation of the safety criteria document will continue into FY 1994. The planned approach and key safety critena that must be met for closure of the Ferrocyanide USQ (see Section 2.4.5) will be addressed in detail. The technical basis for each safety criterion and how each can be met will be presented. The objective of the document will be to show that in situ storage of the waste is safe and to determine if controls should be implemented to ensure safety.

- Problem Areas and Action Taken. The Aerosol Experts Panel that met in March 1992 reviewed available data on the ferrocyanide safety issue and recommended that small-scale aerosol tests be conducted. These tests were originally planned for the second half of FY 1992, but were deferred to FY 1993. Present planning for FY 1993 does not provide for these tests because of resource constraints and because Westinghouse Hanford Company is pursuing a reduced aerosol testing program. 
To obtain information on aerosol generation, the residue from ferrocyanide waste simulant tests at FAI are being analyzed. The amount of cesium lost during the propagation tests will be determined. The In Farm 1 simulant had cesium added to the flowsheet for this purpose. Additional aerosol sampling tests are also being conducted at FAI (see Section 2.5.2). If considerable cesium was lost during the dry simulant burn tests, and in the new tests being conducted at FAI, then a small-scale aerosol test(s) may be conducted to determine a more accurate source term and particle size distribution than possible with the FAI tests. If less than 10 percent of the cesium is lost, small scale testing may not be warranted. The Aerosol Experts Panel will be convened to review the data and make recommendations on future tests.

\section{- Milestone Status -}

- $\quad$ May 31, 1993: Complete the first update of the ferrocyanide hazards assessment document (Grigsby et al. 1992) and issue as an approved public report. This milestone has been deferred to September 30, 1994 to support an update to the ferrocyanide position paper.

- May 31, 1993: Complete small-scale aerosol tests and complete final aerosol report. This work is currently not authorized in the ferrocyanide program budget approved for FY 1993.

- July 31, 1993: Complete parametric and aerosol tests on the most reactive (In Farm 1) flowsheet simulant at FAI and issue a test report approved for public release. This work has been completed at FAI and a report will be issued on schedule.

- September 30, 1993: Complete a final report, approved for public release, on dose consequence recalculations. This milestone has been deferred to FY 1994 in order to focus on preparation of the USQ closure document.

July 1994: Issue a second update of the ferrocyanide hazards assessment document. This milestone is replaced by first update of the hazard assessment, as mentioned above.

\subsubsection{Closure of the Ferrocyanide Unreviewed Safety Question}

Since the inception of the Ferrocyanide Safety Program at Westinghouse Hanford Company, the ultimate objective of the program has been to resolve the ferrocyanide safety issue and show, through safety documentation, that storage of the waste in the tank is safe or to provide for mitigation and/or remediation of the waste, if necessary, until final disposal in the Hanford Waste Vitrification Plant. A key intermediate step in that process is closure of 
the USQ. A new activity was started during the last quarter of FY 1992 to devise a strategy that would be acceptable to DOE and oversight panels for closure, followed by a detailed USQ closure plan.

The DOE order on USQs establishes the process for USQ identification and closure (DOE 1991). The USQ process includes the following steps:

- Identify a situation that may be a potential USQ.

- Take action to place the facility in a safe condition while a safety evaluation is prepared to determine if an actual USQ exists.

- If a USQ is identified, establish the interim-operating conditions for safe operation of the facility while a safety analysis is being performed.

- Perform a safety analysis to close the USQ by establishing a new safety envelope relative to the USQ issue. Potential activities must be within the safety envelope before the USQ is considered closed.

- Incorporate into the existing Safety Analysis Report (SAR) or authorization basis any changes that are needed as a result of the safety evaluation, safety analyses, or other actions taken.

The USQ process depends upon an authorization basis that describes those aspects of the facility design basis and operational requirements relied on by the DOE to authorize operation. The authorization basis is described in documents such as the facility SAR and other safety analyses, Hazard Classification Documents, Technical Safety Requirements, DOE-issued safety evaluation reports, and facility-specific commitments such as the safety assessments (SAs).

The potential hazards of a ferrocyanide-nitrate/nitrite reaction were discovered to represent an inadequacy in the authorization basis. Therefore, an USQ was declared for the ferrocyanide safety issue, and activities in the waste tanks that could increase the likelihood of an accident involving the ferrocyanide-nitrate/nitrite reaction were restricted (Deaton 1990). Until the USQ is closed, proposed intrusive activities that may impact the safety of the ferrocyanide tanks must be assessed for potential safety and environmental consequences. Furthermore, these activities must be authorized by the DOE.

SAs are documents prepared to provide the technical basis to assess the safety of a proposed activity and to provide proper controls to maintain safety. The SA, along with the accompanying environmental assessment (EA), provides the basis for DOE authorization of the proposed activities. 
Since inception of the Ferrocyanide Safety Program, SAs have been completed for vapor space sampling of all ferrocyanide tanks, waste surface sampling, push-mode core sampling, TC tree installation in sound and leaker tanks, and removal of pumpable liquid from leaking tanks (also known as interim stabilization). The SA for push-mode core sampling was revised in June 1993 to accommodate the rotary mode core sampling requirements. The document, along with the EA, was submitted to DOE for review.

Based on SAs authorized to date, a Justification for Continued Operations (JCO) for selected activities in ferrocyanide tanks was prepared and submitted in January 1993 for approval. The following activities are covered in this JCO: vapor sampling or monitoring; small additions of water for special flushes and from intrusion of rainwater and snow melt; nonintrusive activities such as surveillance, LOW scans, instrument calibration and repair, utility installations, and grinding and welding in the vicinity of the tanks; manual surface level monitoring, in-tank photography, installation/removal of instrumentation, HEPA filter testing, and other activities that break tank containment that have already been addressed in safety assessments; waste intrusive operations such as liquid sampling, TC tree installations, LOW installations, saltwell pump installations, push-mode core sampling and auger sampling; and interim stabilization of the ferrocyanide tanks (7) that still contain pumpable liquids. Approval of the JCO will allow Westinghouse Hanford Company to complete the specified activities in accordance with established company policies and procedures without having to obtain DOE approval for each operation. This will reduce the cost and time associated with getting the operations authorized.

The Ferrocyanide USQ Closure Plan was completed and transmitted to the DOE as a predecisional document on January 29, 1993. The approach to be taken and the key safety criteria that must be proven are presented and tiscussed in the plan. Review of the plan by several oversight panels, including the TAP and the Waste Management External Advisory Committee, have been completed; comments are expected from DOE in July 1993.

A decision was made to revise the existing SA for installing TC trees in sound (non-leaking) ferrocyanide tanks so that installation in leaker tanks was addressed as well. A study to evaluate and identify alternative methods for installation of TC trees in assumed leaker ferrocyanide tanks was completed. The previous method used relatively large volumes of water to sluice the TC tree through the waste. An ultra high pressure concept that uses minimal quantities of water was chosen for final testing and design. These documents were transmitted to the DOE in April 1993.

Preparation of a safety assessment for core sampling of ferrocyanide and other Watch List tanks that contain hard waste (e.g., saltcake) has started. This type of sampling will be performed with a rotary drill system. Design and construction of the rotary sampling rig was completed this quarter and has undergone acceptance testing. Operational tests are scheduled to start next quarter. The rotary drill system is expected to be deployed for field operation in October 1993. 
On October 4, 1992, tank 241-T-101 was declared an assumed leaker based on liquid level changes in the tank that had occurred over several months. This was one pf ferrocyanide tanks that require interim stabilization (removal of pumpable liquid). Approval of a safety evaluation was completed, and DOE approval to pump tank 241-T-101 was received. Pumping of 241-T-101 began in March and was completed on April 14, 1993. This tank is now considered to be interim stabilized.

- Progress During the Reporting Period. The revised SA and new EA for installation of TC trees in the assumed leaker ferrocyanide tanks was completed and submitted to the DOE in April.

- Planned Work for Subsequent Months. A technical basis report documenting a safety analysis for closure of the USQ will be prepared. A schedule will not be set until the USQ closure plan is accepted and released.

- Problem Areas and Action Taken. Comments from the DOE have not been received on the Ferrocyanide USQ Closure Plan and this is delaying public release of this document.

- Milestone Status -

October 19, 1992: Submit draft strategy letter to the DOE on the proposed approach for resolution of the ferrocyanide USQ. The letter was transmitted to the DOE on October 28, 1992.

- October 31, 1992: Issue SA and EA documentation to the DOE for rotary-mode core sampling of ferrocyanide tanks. The SA and EA documentation was completed and transmitted to DOE for approval on July $8,1993$.

- January 29, 1993: Submitted predecisional USQ closure plan to DOE providing details on the proposed approach for closure the Ferrocyanide USQ. This milestone was completed on schedule.

February 1, 1993: Received authorization from the DOE, based on revised SA and EA documentation, to proceed with pumping of ferrocyanide tank 241-T-101. This milestone was deferred to February 26, 1993 because the revised SA assessment was not transmitted to the DOE until January 29, 1993. Authorization to pump 241-T-101 was received from the DOE in early March, and pumping commenced on March 12. 
- March 30, 1993: Submit SA and EA documentation for installation of TC trees in assumed leaker ferrocyanide tanks to the DOE for review and comment. The SA and EA were completed and submitted to the DOE in April, 1993 (see Section 2.1.1 for more information regarding TC trees).

- September 1, 1993: Receive authorization from the DOE, based on revised SA and EA documentation, to install remaining TC trees in assumed leaker ferrocyanide tanks.

\subsubsection{Concepts for Resolution of the Ferrocyanide Safety Issue}

A draft report on three approaches evaluated for resolving the ferrocyanide safety issue was issued by Westinghouse Hanford Company in November 1991. Comments were received on the report from TAP, DOE-HQ, and DOE-RL in May 1992. Work on this task since then was directed to revising the report to reflect the latest information available on the ferrocyanide safety issue. Based on this information, Westinghouse Hanford Company has taken the position that in situ safe storage is the safe and viable choice for all the tanks on the Ferrocyanide Watch List.

In January 1993, Westinghouse Hanford Company requested authorization form DOE to remove six tanks from the ferrocyanide Watch List: 241-BX-102, -106, -110, -111, 241-BY-101, and 241-T-101. Historical records for five of the six tanks (241-BX-102, -106, $-110,-111$, and $241-B Y-101)$ show that none of these tanks received any ferrocyanide sludge, although supernatant from other ferrocyanide receiver tanks was temporarily routed to these tanks. Waste transfer records for tank 241-T-101 showed that it received about $10,000 \mathrm{~g}$-moles of ferrocyanide sludge; however, it was subsequently sluiced and emptied (Harmon 1993). If the list of tanks that contain ferrocyanide were to be generated today and the same $1000 \mathrm{~g}$-mole criterion applied, these six tanks would not be included on the list.

- Progress During Reporting Period. Final inputs to the ferrocyanide safe storage were received and the document, title "Proposed Approaches for Safe Storage, Mitigation, and Remediation of Ferrocyanide Waste Tanks at the Hanford Site" will be publicly released next quarter. DOE-HQ has authorized removal of four tanks from the Ferrocyanide Watch List: 241-BX-110, 241-BX-111, 241-BY-101, and 241-T-101. Ciose review of waste transfer records revealed that these tanks contained either a trivial amount of ferrocyanide or no ferrocyanide. DOE also requested additional information on the other two tanks (241-BX-102 and -106), to aid in the decision for removal from the Watch List. 
- Planned Work for Subsequent Months. DOE has requested additional information on the remaining two tanks and also a compilation of the documentation used to reach the decision to stabilize tank 241-T-101. This information, along with the background information on removal of the six tanks, will be compiled into a document to be cleared for public release. The document will be prepared and submitted next quarter.

- Problem Areas and Action Taken. Two additional tanks, 241-BX-102 and 241-BX-106, will be removed from the Watch List once DOE-HQ has received additional documentation that clearly explains what ferrocyanide supernatants were transferred to these tanks. This additional documentation must also include sufficient details of the transfer records showing the amounts of ferrocyanide transferred and where the ferrocyanide currently resides.

- Milestone Status -

- November 30, 1992: Issue a report, approved for public release, on selected concepts and recommendations for resolution of the ferrocyanide safety issue. This milcstone was delayed and release of the report is pending.

\subsection{DEFENSE NUCLEAR FACILITIES SAFETY BOARD RECOMMENDATION 90-7.5 (CHEMICAL REACTION STUDIES)}

"The schedule for the program on study of the chemical properties and explosive behavior of the waste in these tanks is indefinite and does not reflect the urgent need for a comprehensive and definitive assessment of the probability of a violent chemical reaction. The study should be extended to other metallic compounds of ferrocyanide that are known or believed to be present in the tanks, so that conclusions can be generalized as to the range of temperature and other properties needed for a rapid chemical reaction with sodium nitrate."

Chemical reaction studies on ferrocyanide waste simulants are being conducted by Westinghouse Hanford Company, PNL, LANL, Washington State University, and FAI. Westinghouse Hanford Company and PNL have produced flowsheet simulant materials for testing and characterization. PNL is also administering the subcontract with LANL. In FY 1992, LANL completed chemical reaction sensitivity tests on ferrocyanide waste simulants to identify what stimuli (emphasizing non-thermal) may cause a reaction to occur. FAI is conducting adiabatic calorimetry and propagation tests on these same replicated flowsheet materials. The FAI scope of work was expanded in FY 1993 to include selected aerosol studies and, thermal hydraulic modeling of ferrocyanide behavior. 


\subsubsection{Chemical Reaction Studies at Pacific Northwest Laboratory}

Chemical reaction studies are continuing at PNL using flowsheet simulant materials. Waste studies addressing DNFSB Recommendation 90-7.5 were conducted to determine (1) the speciation of cyanides found in the actual tank waste; (2) effects of solid diluents, water, additional fuel sources, and possible catalysts on waste reactivity; (3) the aging effects of more than 35 years of storage in the tanks; and (4) possible microconvection mechanisms that may have allowed mixing of the ferrocyanide sludge with caustic solutions added to the tanks after the ferrocyanide scavenging runs.

- Progress During Reporting Period.

Aging Studies. A series of dissolution experiments were completed this quarter with vendor-prepared sodium nickel ferrocyanide material $\left[\left(\mathrm{Na}_{2} \mathrm{NiFe}(\mathrm{CN})_{6} \cdot \mathrm{Na}_{2} \mathrm{SO}_{4} \cdot 4.5 \mathrm{H}_{2} \mathrm{O}\right)\right]$. Figure 2-11 shows the dissolution of vendor material in aqueous $\mathrm{pH} 13$ solution containing 1 Molar $(\underline{\mathrm{M}})$ sodium ion as carbonate, phosphate, SST simulant salt, and with no added salts. The addition of sodium did inhibit the rate of dissolution for the 144 hour test; however, all of the experiments did approach 90 percent total dissolution.

Dissolution tests were conducted on dicesium nickel ferrocyanide material $\left[\left(\mathrm{Cs}_{2} \mathrm{NiFe}(\mathrm{CN})_{6} \cdot 0.5 \mathrm{CsNO}_{3} \cdot 2.5 \mathrm{H}_{2} \mathrm{O}\right)\right]$. These tests revealed that cesium remains compietely insoluble in 0.1 to $4.0 \mathrm{M} \mathrm{NaOH}$ solutions after stirring for 144 hours at rocm temperature. Infrared spectra indicated that the supernatant solution consists of sodium nitrate and sodium hydroxide, with no dissolved ferrocyanide. Atomic absorption analyses also indicated that no iron was present in solution.

Solubility studies on ferrocyanide sludge simulant material were initiated this quarter. Preliminary results show that the rate of dissolution for the In Farm 2 simulant is slower than the vendor-prepared material under similar conditions (Figure 2-12). The rate of simulant dissolution is generally suppressed relative to the vendor material. Initial dissolution at $\mathrm{pH} 14$ is rapid with a slow increase to about 85 percent dissolution after 144 hours while the vendor material was over 90 percent dissolved after 0.5 hours. In $\mathrm{pH} 13$ solution, the simulant material dissolved very slowly with only about 18 percent in solution after 144 hours. 
Figure 2-11. Dissolution of Vendor Material in Aqueous pH 13 Solution Containing 1 Molar Sodium Ion.

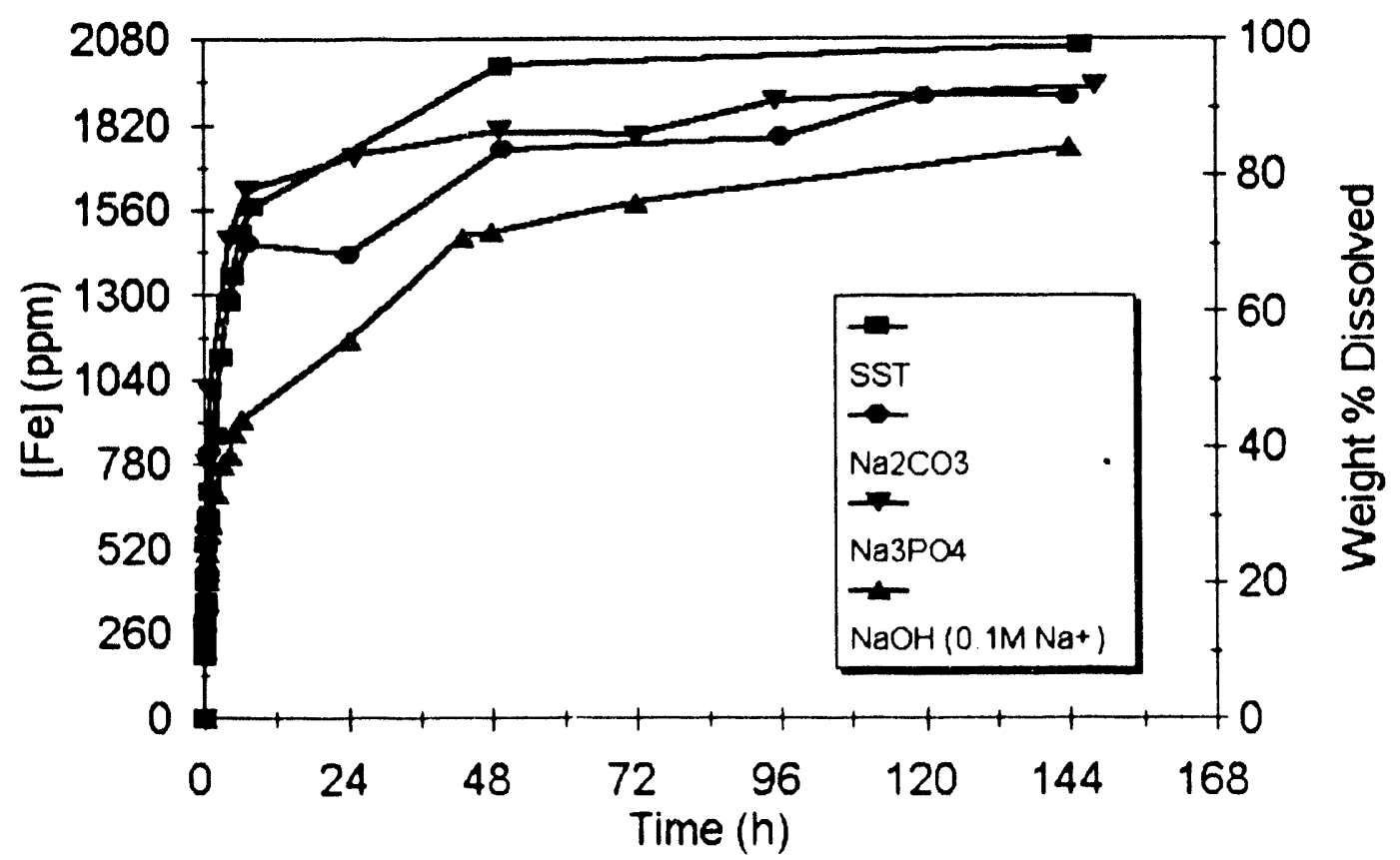

The suppressed rates were probably the result of higher sodium ion concentrations in the simulant. Dissolution of the simulant matrix would increase the sodium ion concentrations about $0.5 \mathrm{M}$. As was the case for the dicesium nickel ferrocyanide dissolution tests, no cesium was solubilized from the simulant waste matrix.

Cyanide Speciation. Fourier transform infrared spectroscopy and ion chromatography (IC) analytical techniques are being developed for quantitative determination of cyanide species in dissolved ferrocyanide waste samples. For both of these techniques, complete dissolution of the cyanide matrix is necessary for an accurate quantitative cyanide analysis. 
Figure 2-12. Solubility of In Farm 2 and Vendor Prepared Ferrocyanide Materials at $\mathrm{pH} 13$ and 14.

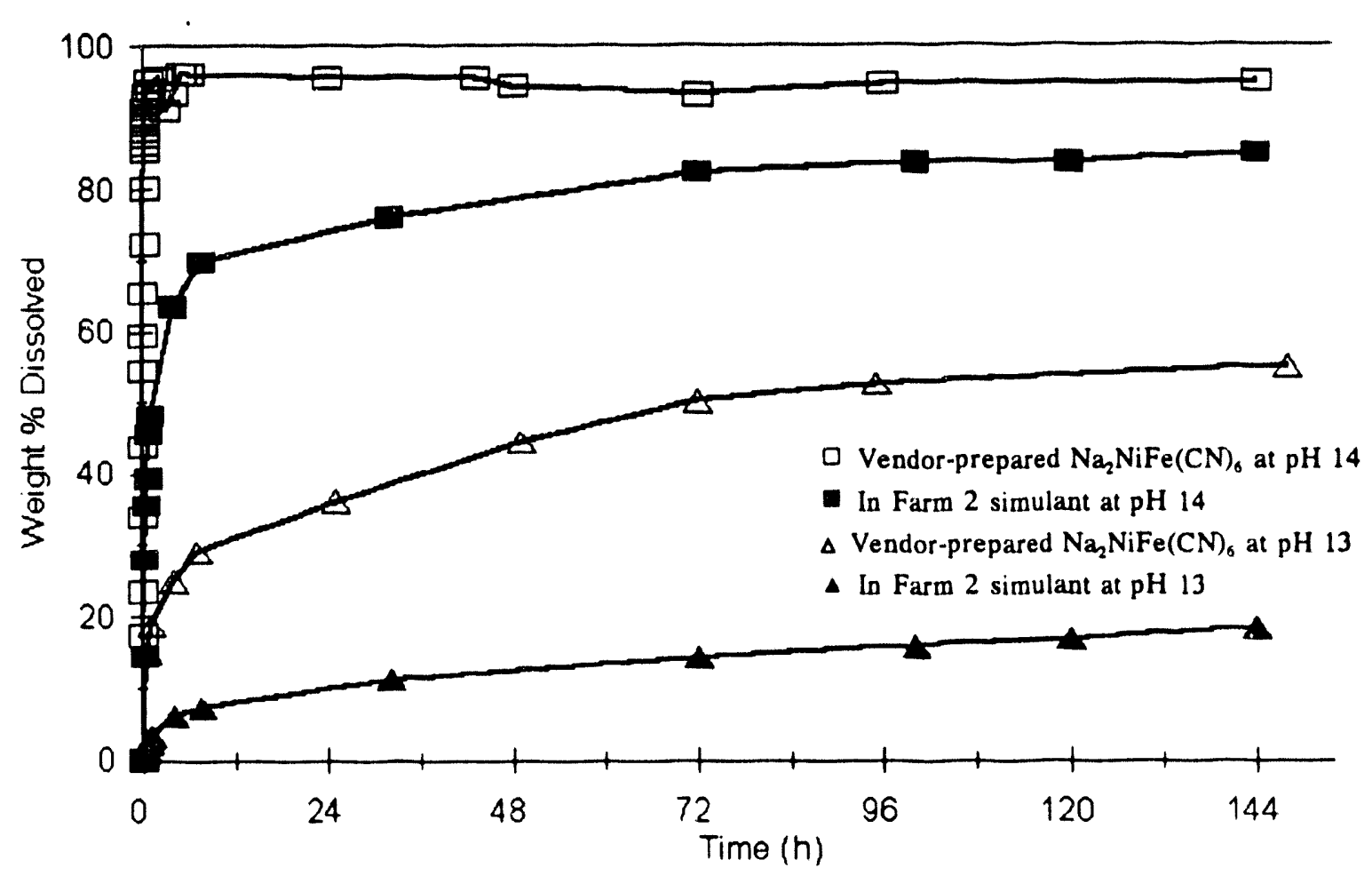

The two most promising solvents considered for dissolution of ferrocyanide waste samples were (1) an aqueous mixture of EDTA and ethylenediamine (en) solution and (2) aqueous sodium hydroxide. Of these two methods, the EDTA/en solution method was judged to be superior for several reasons (Bryan et al. 1992). The use of EDTA/en solution results in complete dissolution of sodium nickel ferrocyanide (Equation 1), while the use of hydroxide results in precipitation of nickel hydroxide (Equation 2).

Precipitation of nickel hydroxide requires the mixture to be filtered before analysis.

(1) $\mathrm{Na}_{2} \mathrm{NiFe}(\mathrm{CN})_{6}(\mathrm{~s})+\mathrm{OH}^{-} \rightarrow 2 \mathrm{Na}^{+}+\mathrm{Fe}(\mathrm{CN})_{6}{ }^{4}+\mathrm{Ni}(\mathrm{OH})_{2}(\mathrm{~s})$

(2) $\mathrm{Na}_{2} \mathrm{NiFe}(\mathrm{CN})_{6}(\mathrm{~s})+\mathrm{EDTA}^{4 \cdot} \rightarrow 2 \mathrm{Na}^{+}+\mathrm{Fe}(\mathrm{CN})_{6}{ }^{4-}+\mathrm{NiY}^{2-}$

Where $\mathrm{Y}$ is $\left[\left(\mathrm{HOOC} \bullet \mathrm{CH}_{2}\right)_{2} \mathrm{~N} \bullet \mathrm{CH}_{2}\right]_{2}$ 
The EDTA/en solution mixture is also an excellent buffer and resists $\mathrm{pH}$ changes with dilution of the sample. This is an important aspect of the EDTA/en solution because of the decreased solubility of sodium nickel ferrocyanide complex at lower $\mathrm{pH}$ values. As the solution is diluted by as much as 10,000 times the original concentration, the $\mathrm{pH}$ is changed by approximately one unit.

Perhaps the biggest advantage of the EDTA/en solution over caustic is its ability to solubilize cesium nickel ferrocyanide compounds. Table 2-2 presents a comparison of dissolution data for a mixture of sodium nickel ferrocyanide and cesium nickel ferrocyanide. The EDTA/en solution dissolved the sodium nickel ferrocyanide completely, while 4 weight percent remained undissolved using sodium hydroxide. Complete dissolution was also achieved for the cesium nickel ferrocyanide compound using the EDTA/en solution, while the sodium hydroxide solvent resulted in no detectable cyanide species in solution.

Table 2-2. Comparison of 5 percent EDTA/en solution and Sodium Hydroxide Dissolution of Sodium Nickel Ferrocyanide and Cesium Nickel Ferrocyanide.

\begin{tabular}{|c|c|c|}
\hline Solvent Tested & $\begin{array}{c}\mathrm{Na}_{2} \mathrm{NiFe}(\mathrm{CN})_{6} \\
(\% \text { Dissolved })^{1}\end{array}$ & $\begin{array}{c}\mathrm{Cs}_{2} \mathrm{NiFe}(\mathrm{CN})_{6} \\
(\% \text { Dissolved })^{1}\end{array}$ \\
\hline $5 \%$ EDTA/en Solution & 100 & 100 \\
\hline $1 \underline{\mathrm{M}} \mathrm{NaOH}$ Solution & 97 & -0 \\
\hline
\end{tabular}

${ }^{1}$ Relative to 5 percent EDTA/en solution.

Interferences with Free Cyanide (CN) Analyses. The effect of potential interferences on cyanide speciation is being evalıated. Test solutions were prepared containing suspected interfering species and free cyanide. The concentration of potential interfering species used in the test solutions were chosen after consideration of ferrocyanide waste flow sheets. Results of the absorbance measurements for the ferrocyanide complex in each of the solutions containing potential interfering species are shown in Figure 2-13. Cyanide concentration data are displayed as the ratio of the measured concentration of that species in each solution to the concentration measured in the standard sample. 
Figure 2-13. Relative Concentration of Free Cyanide in Solution Containing Potential Interferants Compared to Free Cyanide Standard.

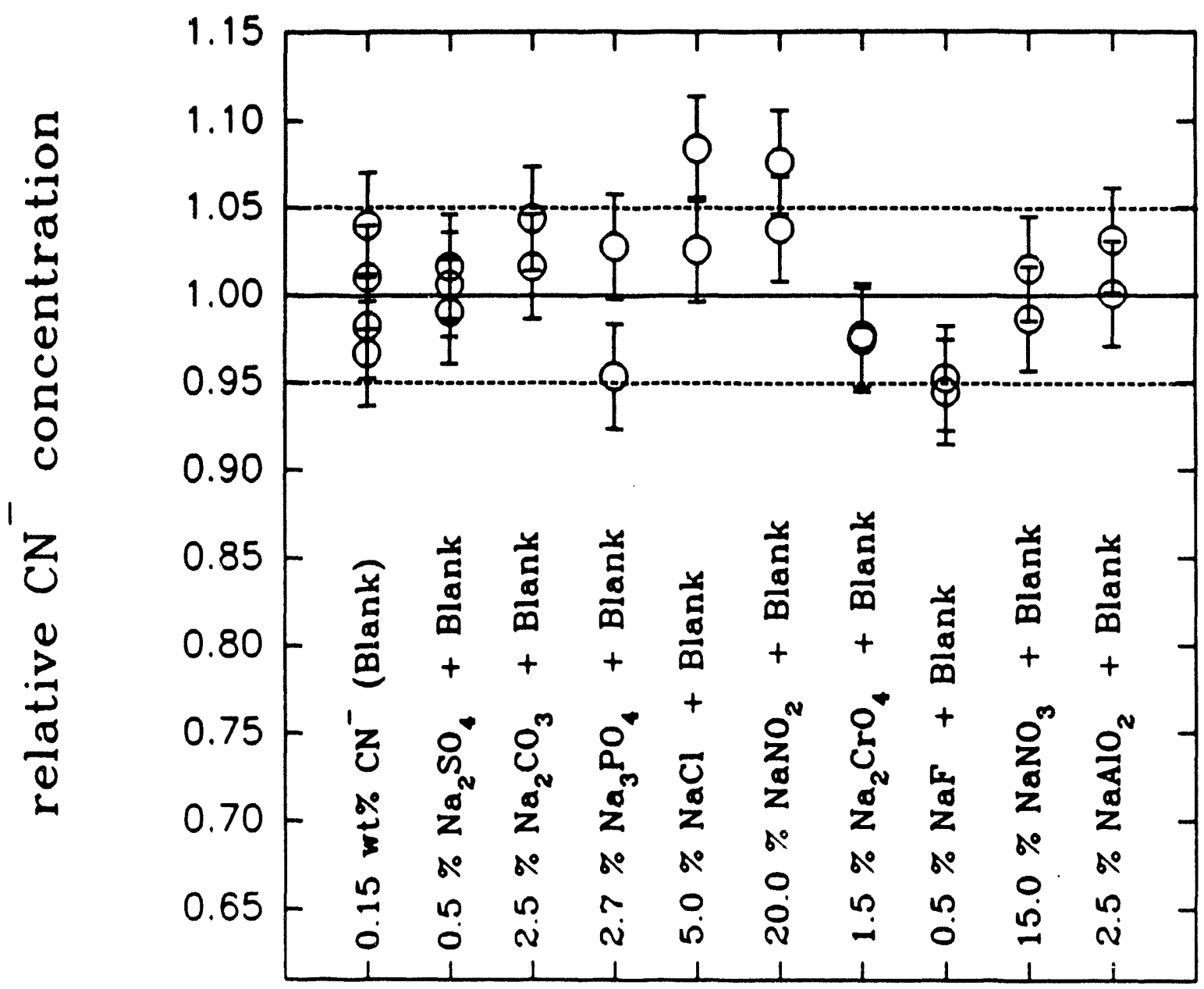

Cyanide concentration measured as $\left[\mathrm{CN}^{-}\right] /[$standard] 
This experiment shows that the presence of the potential interfering species will not change the measured concentration of free cyanide to any appreciable degree. The measured concentration of free cyanide in each solution containing a potential interferant was within 5 percent of the standard solution, except for the solutions containing sodium chloride and sodium nitrite that showed one reading each outside the 5 percent interval around the standard value. These results are very encouraging, especially considering that the concentration of cyanide was on the low extreme expected to be encountered in real waste samples $(0.15$ percent as cyanide in each solution) and the potential interfering species were at the high extreme expected.

A second encouraging result from used experiments is that there was no indication of oxidation of the cyanide ion. No other cyanide containing species was observed in the IR measurements. This was confirmed by excellent agreement in mass balance measurements.

A third important result is that no evidence was seen that any of the potential interferants reacted with the solution cell or attenuated total reflectance (ATR) element used in the experiment. It is critical for the solution cell and ATR element to be inert toward the solutions and species expected to be present within ferrocyanide waste samples.

Diluent Screening and Scoping Studies. A final report, Effect of Potential Waste Constituents on the Reactivity of Ferrocyanide Wastes: Catalyst, Initiator and Diluent Studies (Scheele et al. 1993), was released this quarter. The report discusses investigations of the diluent, catalytic, and initiating effects of potential waste constituents on the reactivity of simulated ferrocyanide wastes. The investigations included studies to (1) determine the effect of the oxidant-to-ferrocyanide ratio, (2) establish the effect of sodium aluminate concentration, (3) identify materials that could affect the reactivity of a mixture of sodium nickel ferricyanide, and (4) determine the effect of nickel sulfide concentrations.

The report includes the results of a thermal sensitivity study conducted to determine the relative behaviors of sodium nickel ferrocyanide and ferricyanide. A statistical evaluation of the time-to-explosion (TTX) test results from the catalyst and initiator screening studies for mixtures containing ferrocyanide and ferricyanide found that the ferricyanide reacted at a faster rate than did the ferrocyanide analog. DSC and thermogravimetric analyses indicated that the ferricyanide form is more thermally sensitive and exhibits exothermic behavior at a lower temperature than the ferrocyanide form. However, analyses to date have shown no ferric iron in the SSTs. 
Based on oxidant-to-ferrocyanide studies, it was found that the range of compositions that produced reactions varied depending upon temperature, with the largest range at the highest temperature. At $400{ }^{\circ} \mathrm{C}$, the mixtures that were reactive ranged from a stoichiometric ratio (oxidant-to-ferrocyanide) of 0.1 to 2.5 . At $320^{\circ} \mathrm{C}$, the reactive compositions ranged from a stoichiometric ratio of 0.5 to 1.0. Mixtures having less or more oxidant did not react.

Studies conducted to determine the effect of an inert diluent found that sodium aluminate delays the reaction, but even at a weight ratio of $12: 1$ $\left.\left[\mathrm{NaAlO}_{2}: \mathrm{Na}_{2} \mathrm{NiFeCN}\right)_{6}\right]$, the ferrocyanide mixture continued to react at $350{ }^{\circ} \mathrm{C}$. Additional work was conducted to determine the diluent effects of other potential ferrocyanide waste constituents on the reactivity of ferrocyanide and nitrate/nitrite mixtures. Results showed that the higher heat capacity equimolar sodium nitrate and nitrite was more effective in preventing a reaction than the lower heat capacity sodium aluminate.

Nickel sulfide results indicate that nickel sulfide increases the reactivity of a mixture of sodium nickel ferrocyanide and equimolar sodium nitrate and nitrite. Adding nickel sulfide accelerated the reaction and reduced the minimum observed reaction temperature to about $260{ }^{\circ} \mathrm{C}$. However, it should be noted that this temperature is still over $200{ }^{\circ} \mathrm{C}$ greater that the highest current temperature found in a ferrocyanide tank (approximately $55^{\circ} \mathrm{C}$ ).

Microconvection Modeling. Microconvection modeling studies are being conducted to determine if there are mechanisms that could potentially mix the caustic chemical liquids that were added later to ferrocyanide tanks. If such "convection cell" mechanisms are possible, the high caustic liquids would solubilize the sodium and/or cesium nickel ferrocyanide by conversion to water soluble ferrocyanide. The dissolved cyanide complex might then be destroyed by hydrolysis/radiolysis, or be removed from the tank during subsequent liquid transfer operations.

Solubilization and transport of the ferrocyanide would have two effects. First, it would reduce the fuel concentration in the sludge. Second, in the event of an exotherm, the dose consequences of a runaway reaction would be reduced because the amount of cesium available for dispersion would be smaller. Such a phenomenon could account for the lower than anticipated levels of cyanide determined in tank samples analyzed to date.

Fluid stability analyses conducted to date indicate that a dense fluid layer overlying a porous medium saturated by a less dense fluid is an unstable configuration and leads to finger-like convective mixing. This mechanism could result in convective mixing of the alkaline liquid wastes in the tanks. 
Development of a two-dimensional diffusion-convection model with chemical reaction to analyze the mobilization and transport of cesium nickel ferrocyanide is 90 percent complete. This model can determine mixing as a simultaneous function of heat transfer, mass transport, and chemical reaction equations. The numerical algorithms have been verified against published analytical and numerical solutions to standard heat conduction problems. A graphical user interface was developed to simplify problem setup and to display the comrutational results. Output can be viewed in either tabular format or in a high-resolution two dimensional color map of temperatures or element concentrations.

- Planned Work For Subsequent Months. Dissolution and hydrolysis aging studies will be continued. Experiments will delineate the effects of temperature and gamma radiation on Westinghouse Hanford Company prepared ferrocyanide waste simulants. A report summarizing work completed in FY 1993 will be published next quarter.

Work on cyanide speciation analytical methods, including IC methods and solution IR methods, will continue. Probable interferences that may be encountered in developing analytical methods for actual waste samples will be determined. Work will also continue on solids speciation of flowsheet simulants using IR and Raman techniques.

A report on microconvection modeling with results, conclusions and recommendations on this activity will be completed next quarter.

- Problem Areas and Action Taken. None.

- Milestone Status -

- November 27, 1992: Transmit a final, cleared report on FY 1992 Aging Studies to the DOE; the report (Lilga et al. 1992) was issued on November 25, 1992.

- January 22, 1993: Transmit a draft report on FY 1992 PNL catalyst, initiator, and diluent screening studies to Westinghouse Hanford Company review and clearance. The draft report was submitted to Westinghouse Hanford Company on January 22, 1993 for review.

- April 30, 1993: Issue a final PNL report on catalyst, initiator, and diluent studies that is approved for public release. Copies of the cleared final report, titled Effect of Potential Waste Constituents on the Reactivity of Ferrocyanide Wastes: Catalyst, Initiator and Diluent Studies (Scheele et al. 1993) were delivered to Westinghouse Hanford Company on April 30, 1993. 
- June 30, 1993: Issue the final, cleared report on small-scale sensitivity tests of ferrocyanide flowsheet simulants conducted by LANL. The report (Cady 1993) was delivered to Westinghouse Hanford Company on June 15, 1993.

- September 20, 1993: Issue a PNL report, approved for public release, on FY 1993 ferrocyanide microconvection modeling activities.

- September 20, 1993. Issue a final PNL report, approved for public release, on ferrocyanide speciation method development and deployment of a system in PNL hot cells or laboratory hoods.

- September 30, 1993: Issue a cleared PNL report on the results of aging studies on ferrocyanide waste to Westinghouse Hanford Company for transmittal to DOE.

\subsubsection{Ferrocyanide Propagation Studies}

Ferrocyanide adiabatic calorimetry and propagation tests are continuing at FAI under contract to Westinghouse Hanford Company. The results of these tests are being used to help determine if Hanford Site ferrocyanide waste will ignite and burn to spread and involve additional waste from a potential ignition point and to determine the potential for release of radioactive species under postulated accident conditions. Tests were conducted with dried simulant to evaluate safety concerns associated with postulated hot spot accident conditions. The propagation velocity is a key parameter in determining safety consequences of postulated burns, including a potential radioactivity release from confinement.

Because the composition of the waste in the storage tanks varies and is unknown at all locations, ranges of material compositions have been tested. In all cores the waste simulants being tested were formulated to be conservative; i.e., the fuel value is slightly greater than shown in the original flowsheets. Present work is focused on T Plant and more reactive In Farm 1 simulants. Sludge produced by the In Farm flowsheet was transferred to four C Farm tanks and represents about 26 percent of the total ferrocyanide used in the Hanford Site scavenging processes. Sludge produced by the T Plant flowsheet was transferred to three TY Farm tanks and represents about 8 percent of the total ferrocyanide used during the Hanford Site scavenging processes. Adiabatic calorimeter tests have also been initiated to assess organic contributions to the total enthalpy from ferrocyanide sludges during heat up to high temperatures.

The present concentration of ferrocyanide in the sludge is in question because ferrocyanide has been shown to hydrolyze in the presence of high $\mathrm{pH}$ waste (see Section 2.5.1). Initial sample results of $\mathrm{C}$ Farm tank waste indicate that the waste ferrocyanide concentrations are at considerably lower concentrations than the In Farm simulants being tested. 
- Progress During Reporting Period. T Plant ferrocyanide waste simulant was prepared and sent to FAI for adiabatic calorimetry tests. The ferrocyanide concentration in the upper fraction of T Plant simulant (Section 2.4.2) is expected to be similar to the U Plant simulant in exothermic behavior. The lower fraction did not exhibit exothermic properties during DSC tests at Westinghouse Hanford Company.

Gas injection tests were conducted by FAI to determine if the ferrocyanide sludge behaves as a porous bed medium or if the sludge moves as a homogeneous mixture. This information is important for determining if a postulated hot spot could dry out a small region of waste.

Nitrogen was injected into In Farm 1 simulant and wet kaolin clay to determine flow behavior under conditions of gas formation. The gas formed a single bubble that pushed the simulant and clay away from the point of gas injection for tests conducted in 4.45 and $12.7 \mathrm{~cm}$ diameter columns. The In Farm simulant and kaolin clay behaved as homogeneous materials because of their small particle size.

Homogeneous flow behavior would preclude the formation of a dry spot in actual tank waste. The heat generated by a postulated hot spot would cause a vapor pocket to form around it. The vapor pocket would expand until the heat loss by conduction is balanced with the heat generated. An equilibrium would be established and a stable, self-regulated vapor pocket would exist.

Adiabatic calorimetry tests have been initiated to determine the potential additional energy release contributions from low concentrations of organics which may be in the ferrocyanide waste. Three organics are to be evaluated: (1) sodium acetate, which represents an average energy producing organic carbon; (2) sodium stearate, which represents a high energy producing organic carbon; and (3) sodium oxalate, which represents an end product of degradation reactions believed to be occurring in the waste tanks. These experiments will be completed next quarter.

- Planned Work for Subsequent Months. Propagation screening tests to identify the most important parameters will be conducted. Additional parametric and ferrocyanide/organic tests will be developed and initiated at FAI. Calorimetry tests will continue on the T Plant ferrocyanide waste simulant. The residues from aerosol tests using In Farm 1 samples will be analyzed to identify reaction products. The fraction of cesium released during the aerosol tests will also be determined. Adiabatic calorimeter studies on ferrocyanide simulant sludges spiked with organics will continue. 
- Milestone Status -

- December 31, 1992: Define parametric and aerosol sampling tests to be conducted at FAI using In Farm and U Plant Flowsheet ferrocyanide waste simulants. Parametric tests and the scope of aerosol tests to be conducted at FAI were defined with Dr. H. K. Fauske, of FAI on December 10, 1992. The letter to FAI authorizing these tests was issued January 12, 1993.

- January 29, 1993: Complete pressure parametric and confined scoping aerosol/propagation tests on the most reactive simulant at FAI. This work was completed on schedule. Reports (Fauske 1993a, 1993b) were issued.

- May 14, 1993: Prepare and ship T Plant and U Plant 1 simulants to FAI for calorimetric and dry out tests, respectively. This milestone was completed as scheduled.

- June 30, 1993: Complete a report, approved for public release, on $\mathrm{T}$ Plant calorimetry and propagation tests, and U Plant dry out tests. This will be issued next quarter.

- July 30, 1993: Complete a report on parametric and selected aerosol tests on the most reactive (In Farm 1) flowsheet simulant at FAI and issue a test report that is approved for public release.

- September 30, 1993: Complete ferrocyanide/organic calorimetry scanning tests and issue a test report that is approved for public release. 


\subsection{DEFENSE NUCLEAR FACILITIES SAFETY BOARD RECOMMENDATION 90-7.6 (EMERGENCY RESPONSE PLANNING)}

"The Board had recommended 'that an action plan be developed for the measures to be taken to neutralize the conditions that may be signaled by alarms.' Two types of measures are implied: actions to respond to unexpected degradation of a tank or its contents, and actions to be taken if an explosion were to occur. Your implementation plan stated that the current contingency plans. . . . will be reviewed and revised if needed.' We do not consider that this proposed implementation of the Board's recommendation is adequately responsive. It is recommended that a written action plan founded on demonstrated principles be prepared as soon as possible, that would respond to indications of onset of abnormal temperatures or other unusual conditions in a ferrocyanide-bearing tank, to counter any perceived growth in hazard. A separate emergency plan should be formulated and instituted, covering measures that would be taken in event of an explosion or other event leading to an airborne release of radioactive material from the tanks, and that would protect personnel both on and off the Hanford Site. The Board believes that even though it is considered that the probability is small that such an event will occur, prudence dictates that steps be taken at this time to prepare the means to mitigate the unacceptable results that could ensue."

\subsubsection{Action Plan for Response to Abnormal Conditions}

The Action Plan for Response to Abnormal Conditions in Hanford Radioactive Waste Tanks Containing Ferrocyanide (Cash and Thurman 1991a) was prepared in response to DNFSB recommendations. The action plan describes the steps to be taken if a temperature increase trend above the tank temperature baseline is measured in any of the ferrocyanide tanks. The document was revised in December 1991 and reissued as WHC-EP-0407, Rev. 1 (Cash and Thurman 1991b) to include the monitoring criteria and responses for abnormal levels of flammable and toxic gases, as well as the reporting requirements if established criteria are exceeded.

Also addressed in this section are actions in response to other abnormal conditions that might be encountered with the ferrocyanide tanks, such as a leak to the environment. For the ferrocyanide tanks, 14 are classified as assumed leakers, including 241-T-101, which was added to the assumed leaker list of tanks on October 4, 1992. Six of the assumed leaker tanks have not been interim stabilized. Seven tanks still require some pumping to be classified as interim stabilized. Authorization to pump these tanks must be granted by DOE because the activity involves the Ferrocyanide USQ. This authorization requires that SA and EA documentation be prepared for this activity. The status of the SA and EA is discussed in Section 2.4.5.

- Progress During the Reporting Period. Both the SA and the EA for removing pumpable liquids from ferrocyanide tanks were submitted to DOE for review on September 30, 1992. Comments were received on the documents in early January and they were revised and resubmitted at the end 
of January. Additional comments on the EA were received from DOE on March 31, 1993 and have now been addressed. Further comments are expected from DOE-RL in July. A request for authorization for stabilization and emergency pumping of the ferrocyanide tanks was submitted to DOE.

Emergency pumping of tank 241-T-101, commenced on March 12, 1993. Stabilization of the tank was completed on April 14 with $95,700 \mathrm{~L}$ (25,300 gallons) of liquid removed. This tank was just recently removed from the Ferrocyanide Watch List (Section 2.4.6).

On April 1, 1993, Westinghouse Hanford Company notified DOE that reportable quantities may have leaked from tank 241-BX-111. Westinghouse Hanford Company evaluated the surveillance data available on this tank and declared this tank to be an "assumed re-leaker" since the tank had already been declared to bs: an "assumed leaker" several years ago. Plans are now underway to pump this tank as well.

- Planned Work for Subsequent Months. Comments received from DOE on the SA and EA will be resolved and the document will be resubmitted to DOE.

Plans for interim stabilization of the seven ferrocyanide tanks (excluding 241-T-101) reniaining to be pumped will proceed as soon as authorization is received from DOE. Each tank will undergo a thorough readiness review before commencing pumping operations.

- Problem Areas and Action Taken. None.

- Milestone Status -

August 31, 1992: Issue a draft SA for saltwell pumping (stabilization) of ferrocyanide tanks to the DOE. This SA will be applicable to tanks that may need to be pumped because of a leak. This milestone was met on September 30, 1992.

- September 30, 1992: Issue recommendations on the feasibility and safety of stabilizing single-shell ferrocyanide tanks. These recommendations should also address actions to be taken if a tank shows evidence of a leak. The recommendation letter, together with the SA for interim stabilization of ferrocyanide tanks, was delivered to the DOE on September 30, 1992. 
- December 31, 1992: Incorporate comments into the SA and EA documents, as appropriate, and submit revised documents to the DOE for review. The EA was revised and resubmitted to the DOE in December and the SA was not submitted until January 25, 1993. A second revision of the EA was transmitted on January 29, 1993.

- February 1, 1993: Receive authorization from the DOE, based on revised SA and EA documentation, to proceed with pumping of leaking ferrocyanide tank 241-T-101. The scheduled date for initiation of pumping was changed to the first part of March 1993. Authorization was received in March and pumping was completed on April 14, 1993.

- September 30, 1993: Complete revisions, as required, to the SA and EA for interim stabilization of the seven remaining ferrocyanide tanks and resubmit the documents to DOE for authorization to proceed.

- March 31, 1994: Complete an evaluation report to determine which gases, if any, need to be continuously monitored on selected ferrocyanide tanks (see Section 2.3 for more information regarding gas monitoring).

\subsubsection{Response to an Airborne Release From a Ferrocyanide Tank}

If a radioactive release from a ferrocyanide tank were to occur, it would be detected by one or more radiation monitoring systems. Significant airborne or ground surface releases that spread beyond the immediate tank or tank farm would be detected by the tank farm area radiation detectors. These monitoring systems are on all tank farms. An emergency involving an underground radioactive waste storage tank is a unique event with potentially serious consequences both onsite and offsite. The DOE and Westinghouse Hanforu Company have analyzed the potential impacts of an event involving one of these tanks, and have taken additional steps so that emergency personnel can take mitigating actions in a timely fashion. These analyses resulted in development of the Tank Farm Emergency Response Stabilization Plan (WHC 1991) in March 1991. The plan includes predetermined mitigative actions for tisminating the emergency phase and providing a transition to the recovery phase. Acknowledging that an event could range from minor to major releases, the plan addresses responses in four distinct and defined steps that will cover the range of consequences. The Stabilization Plan provides quick, preplanned actions that can be used to stabilize an emergency event at an underground radioactive waste storage tank. 
- Progress During Reporting Period. As noted in previous reports, all of the planned milestones for this task were completed.

- Planned Work For Subsequent Months. None planned.

- Problem Areas and Action Taken. None.

- Milestone Status. None applicable. 


\subsection{SCHEDULES}

The schedules presented in this section are those provided by the revised implementation plan, WHC-EP-0415, Rev. 1 (Borsheim et al. 1992). The schedules have been statused for the third quarter of FY 1993, ending June 30, 1993. Work on the Ferrocyanide Safety Program is shown for FY 1991 through FY 1994. Because the scope of some of the program activities has changed over the past two years, it is appropriate that progress be tracked against this new schedule.

The new schedule was expanded to four pages, and is laid out in a slightly different format that is easier to read. Activities that have started or been completed are indicated by triangles that are filled in. Work indicated by open triangles has either not started or has not been completed. A status line will be drawn each quarter showing the progress completed on each activity. 

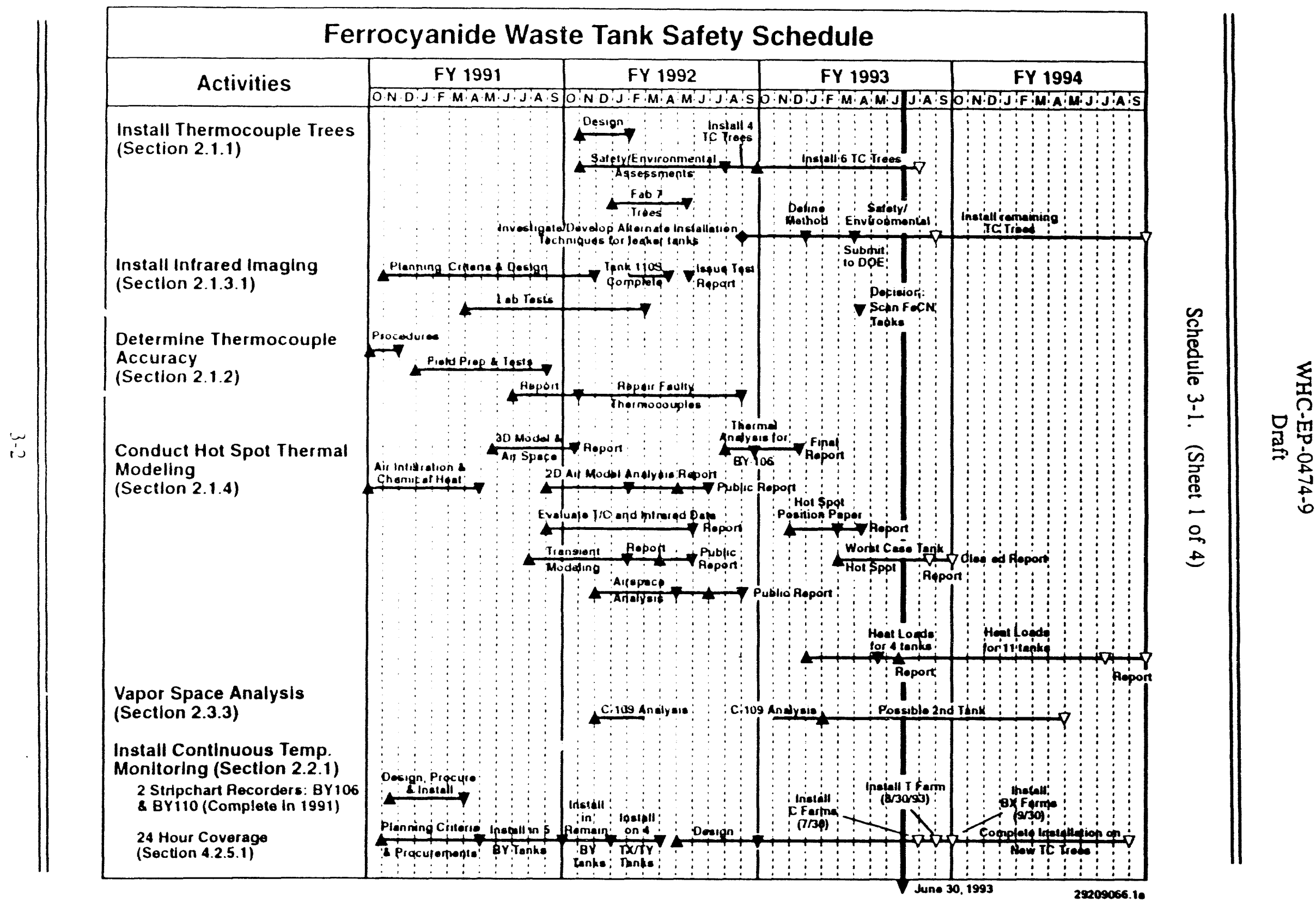


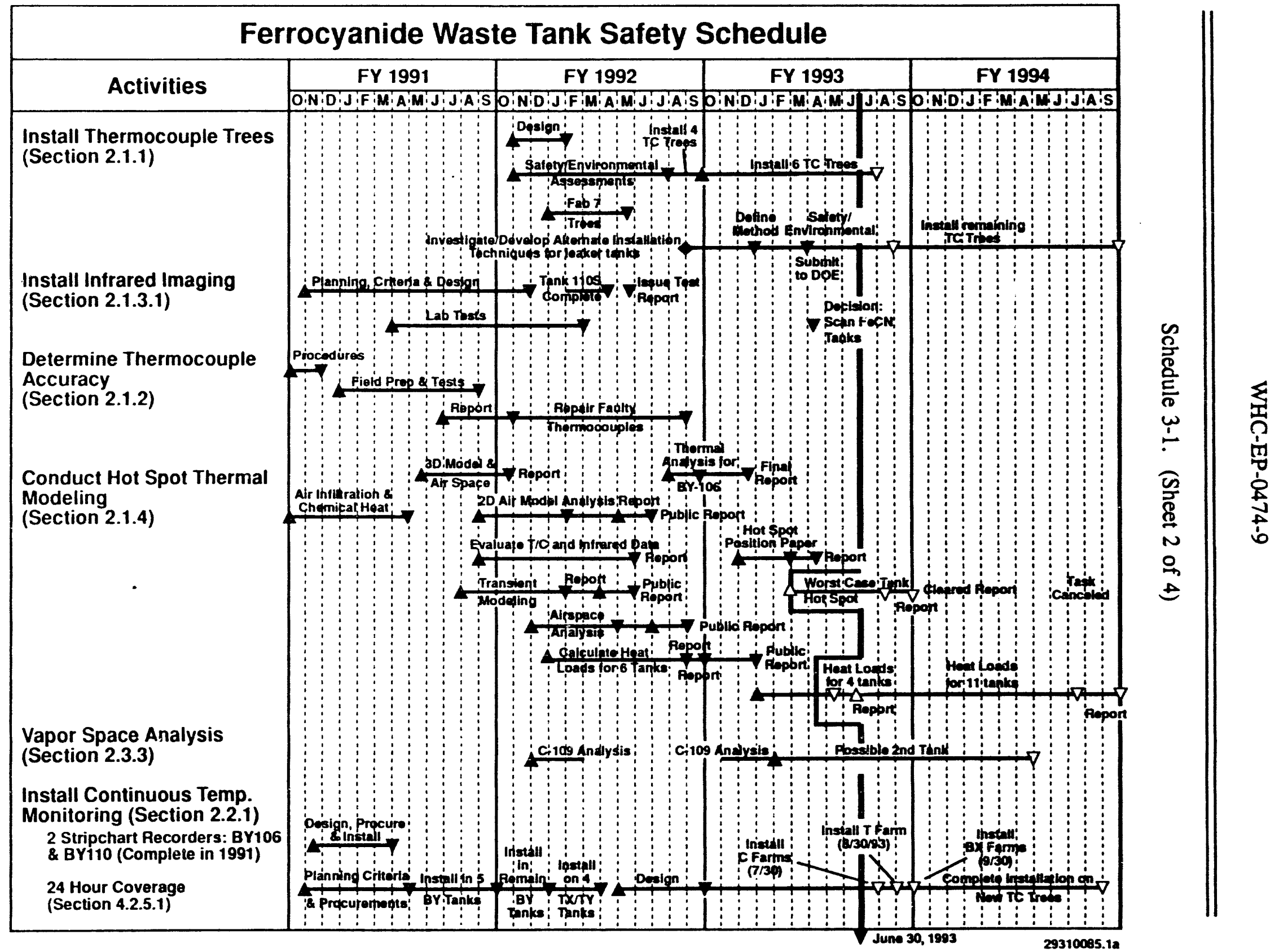


This page intentionally left blank. 


\subsection{REFERENCES}

Bergmann, L. M., 1986, Single-Shell Tank Isolation Safery Analysis Report, WHC-SD-WM-SAR-006, Rev. 2, Westinghouse Hanford Company, Richland, Washington.

Borsheim, G. L., and B. C. Simpson, 1991, An Assessment of the Inventories of the Ferrocyanide Watch List Tanks, WHC-SD-WM-ER-133, Rev. 0, Westinghouse Hanford Company, Richland, Washington.

Borsheim, G. L., R. J. Cash, and G. T. Dukelow, 1992, Implementation Plan for the Defense Nuclear Facilities Safety Board Recommendation 90-7, WHC-EP-0415, Rev. 1, Westinghouse Hanford Company, Richland, Washington.

Brown, T. M., and L. Jensen, 1993, Tank Characterization Report for Single-Shell Tank 241-U-110, WHC-EP-0643, Rev. 1, Westinghouse Hanford Company, Richland, Washington.

Bryan, S. A., K. H. Pool, L. L. Burger, C. D. Carlson, J. L. Ryan, R. D. Scheele, and J. M. Tingey, 1992, Ferrocyanide Safety Project-- Task 3.5 - Cyanide Species Analytical Methods Development, FY 1992 Annual Report, PNL-8399, Pacific Northwest Laboratory, Richland, Washington.

Burger, L. L., 1989, Complexant Stability Investigation, Task 1-Ferrocyanide Solids, PNL-5441, Pacific Northwest Laboratory, Richland, Washington.

Burger, L. L., and R. D. Scheele, 1988, Interim Report - Cyanide Safety Studies, PNL-7175, Pacific Northwest Laboratory, Richland, Washington.

Bussell, J. H., 1992, Engineering Evaluation of Thermocouples in Ferrocyanide Watch List Tanks, WHC-SD-WM-ER-134, Rev. 0, Westinghouse Hanford Company, Richland, Washington.

Cady, H. H., 1993, Evaluation of Ferrocyanide/Nitrate Explosive Hazard, LA-12589-MS, Los Alamos National Laboratory, Los Alamos, New Mexico.

Cash, R. J., 1991, Implementation Plan for the Defense Nuclear Facilities Safety Board Recommendation 90-7, WHC-EP-0415, Westinghouse Hanford Company, Richland, Washington.

Cash, R. J., and J. M. Thurman, 1991a, Action Plan for Response to Abnormal Conditions in Hanford Site Radioactive Waste Tanks Containing Ferrocyanide, WHC-EP-0407, Westinghouse Hanford Company, Richland, Washington. 
Cash, R. J., and J. M. Thurman, 1991b, Action Plan for Response to Abnormal Conditions in Hanford Site Radioactive Waste Tanks Containing Ferrocyanide, WHC-EP-0407, Rev. 1, Westinghouse Hanford Company, Richland, Washington.

Deaton, D. E., 1990, Unusual Occurrence-Unreviewed Safety Questions Regarding Tanks Containing Ferrocyanide, WHC-90-B003-R1, Update 10-22-90, Westinghouse Hanford Company, Richland, Washington.

Dickinson, D. R., J. M. McLaren, G. L. Borsheim, and M. D. Crippen, 1993, Ferrocyanide Safety Program: Credibility of Drying Out Ferrocyanide Tank Waste by Hot Spots, WHC-EP-0648, Rev. 0, Westinghouse Hanford Company, Richland, Washington.

DOE, 1987, Final Environmental Impact Statement - Disposal of Hanford Defense High-Level, Transuranic, and Tank Wastes, Vols. 1-5, DOE/EIS-0113, U.S. Department of Energy, Washington, D.C.

DOE, 1990, "DOE to Develop Supplemental Environmental Impact Statement for Hanford," press release (October 9, 1990), U.S. Department of Energy, Washington, D.C.

DOE, 1991, Unreviewed Safery Questions, DOE Order 5480.21, U.S. Department of Energy, Washington, D.C.

Ecology, EPA, and DOE, 1989, Hanford Federal Facility Agreement and Consent Order, 2 vols, as amended, Washington State Department of Ecology, U.S. Environmental Protection Agency, and U.S. Department of Energy, Olympia, Washington.

Fauske, H. K., 1992, Adiabatic Calorimetry and Reaction Propagation Rate Tests with Synthetic Ferrocyanide Materials Including U Plant 1, U Plant 2, In Farm 1, In Farm 2 and Vendor Procured Sodium Nickel Ferrocyanide, WHC-SD-WM-RPT-054, Rev. 0, Westinghouse Hanford Company, Richland, Washington.

Fauske, H. K., 1993a, Summary Report on Parametric Pressure Propagation Tests T0127-1 and T0128-1, WHC-EP-0661, Westinghouse Hanford Company, Richland, Washington.

Fauske, H. K., 1993b, Summary Report on 49L Ferrocyanide Aerosol Tests T0208-1 and T0209-1, WHC-EP-0662, Westinghouse Hanford Company, Richland, Washington.

FR, 1990, "Implementation Plan for Recommendation 90-3 at the Department of Energy's Hanford Site, Washington," Federal Register, Defense Nuclear Facilities Safety Board Recommendation 90-7, Vol. 55, No. 202, pp. 42243 - 42244. 
Grigsby, J. M., D. B. Bechtold, G. L. Borsheim, M. D. Crippen, D. R. Dickinson, G. L. Fox, D. W. Jeppson, M. Kummerer, J. M. McCormack, A. Padilla, B. C. Simpson, and D. D. Stepnewski, 1992, Ferrocyanide Waste Tank Hazard Assessment--Interim Report, WHC-SD-WM-RPT-032, Rev. 1, Westinghouse Hanford Company, Richland, Washington.

Hanlon, B. M., 1993, Tank Farm Surveillance and Waste Status Summary Report for June 1993, WHC-EP-0182-62, Westinghouse Hanford Company, Richland, Washington.

Harmon, H. D., 1993, Ferrocyanide Safety Program - Removal of Six Tanks from Ferrocyanide Tank List, (Letter 9259120 to John H. Anttonen, Acting Program Manager, Office of Tank Waste Remediation System, U. S. DOE, Richland Field Office, Richland, Washington), Westinghouse Hanford Company, Richland, Washington.

Jeppson, D. W., and J. J. Wong, 1993, Ferrocyanide Waste Simulant Characterization, WHC-EP-0631, Westinghouse Hanford Company, Richland, Washington.

Lilga, M. A., M. R. Lumetta, W. R. Riemath, R. A. Romine, and G. F. Schiefelbein, 1992, Ferrocyanide Safety Project Subtask 3.4 - Aging Studies FY 1992 Annual Report, PNL-8387, Pacific Northwest Laboratory, Richland, Washington.

McLaren, J. M., 1993, Ferrocyanide Safety Program: Thermal Analysis of Tank 241-BY 106, WHC-EP-0591, Rev. 0, Westinghouse Hanford Company, Richland, Washington.

Meacham, J. E., H. Babad, and H. Toffer, 1993, Moisture Monitoring of Ferrocyanide Tanks: An Evaluation of Methods and Tools, WHC-EP-0658, Westinghouse Hanford Company, Richland, Washington.

Neskas, J. W., and G. L. Borsheim, 1993, Data Interpretation Report on Tank 241-BY-104 Auger Samples, WHC-SD-WM-RPT-068, Rev. 0, Westinghouse Hanford Company, Richland, Washington.

Peach, J. D., 1990, "Consequences of Explosion of Hanford's Single-Shell Tanks Are Understated," (Letter B-241479 to C. M. Synar, Chairman of Environment, Energy and Natural Resources Subcommittee, Committee on Government Operations, House of Representatives), GAO/RCED-91-34, General Accounting Office, Washington, D.C.

Postma, A. K., H. Babad, R. J. Cash, and J. L. Deichman, 1992, Current Understanding of the Safety of Storing High-Level Waste Containing Ferrocyanide at the Hanford Site, WHC-EP-0531, Rev. 1, Westinghouse Hanford Company, Richland, Washington. 
Scheele, R. D., J. W. Johnston, J. M. Tingey, L. L. Burger, and R. L. Sell, 1993, Effect of Potential Waste Constituents on the Reactivity of Hanford Ferrocyanide Wastes: Diluent, Catalyst, and Initiator Studies, PNL-8649, Pacific Northwest Laboratory, Richland, Washington.

Wood, S. A., 1993, Gas Space Analysis for Tank C-109, WHC-SD-WM-ER-183, Rev. 0, Westinghouse Hanford Company, Richland, Washington. 


\section{APPENDIX \\ LIST OF FERROCYANIDE TANKS}

App-1 
This page intentionally left blank.

App-2 
Table A-1. Summary of Contents and Status of Ferrocyanide Tanks'.

\begin{tabular}{|c|c|c|c|c|c|c|}
\hline Tank & $\begin{array}{l}\text { Total waste } \\
\text { volume } \\
(1,000 \text { gal })\end{array}$ & $\begin{array}{c}\mathrm{FeCN}^{\mathrm{b}} \\
\left(1,000 \mathrm{~g} \mathrm{~mol}^{2}\right)\end{array}$ & $\begin{array}{c}\text { Heat. load }(1,000 \\
\text { Btu/h })^{c}\end{array}$ & & $\begin{array}{l}\text { num } \\
\text { p. } \\
\left({ }^{\circ} \mathrm{F}\right)\end{array}$ & Status of $\tan k s^{e}$ \\
\hline BX-102 & 96 & $<1$ & $<10$ & 17 & 63 & IS; AL \\
\hline BX-106 & 46 & $<1$ & $<10$ & 17 & 63 & NS; Sound \\
\hline BY -103 & 400 & 66 & 8.6 & 28 & 82 & NS; AL \\
\hline BY-104 & 406 & 83 & $5.5-11.0^{d}$ & & $\begin{array}{l}127 \\
116\end{array}$ & IS; Sound \\
\hline BY -105 & 503 & 36 & $4.0-8.0^{d}$ & $\begin{array}{l}46 \\
50\end{array}$ & $\begin{array}{l}115 \\
122\end{array}$ & NS; AL \\
\hline BY -106 & 642 & 70 & $5.5-11.0^{d}$ & 54 & 130 & NS; AL \\
\hline BY -107 & 266 & 42 & 14.5 & 36 & 96 & IS; AL \\
\hline BY -108 & 228 & 58 & $4.4-8.8^{d}$ & 43 & 109 & IS; AL \\
\hline BY -110 & 398 & 71 & $4.0-8.0^{d}$ & $\begin{array}{l}48 \\
43^{f}\end{array}$ & $\begin{array}{l}118 \\
110\end{array}$ & IS; Sound \\
\hline BY -111 & 459 & 6 & $2.4-4.8^{d}$ & $\begin{array}{l}30 \\
31^{\mathrm{f}}\end{array}$ & & IS; Sound \\
\hline BY -112 & 291 & 2 & $<10$ & $\begin{array}{l}28 \\
31^{f}\end{array}$ & & IS; Sound \\
\hline$C-108$ & 66 & 25 & $<10$ & 22 & 71 & IS; Sound \\
\hline C- 109 & 66 & 30 & $3.5-7.0^{d}$ & $\begin{array}{l}23 \\
24^{\mathrm{f}}\end{array}$ & & IS; Sound \\
\hline$C-111$ & 57 & 33 & $<10$ & 21 & 70 & IS; AL \\
\hline C- 112 & 104 & 31 & $<10$ & $\begin{array}{l}25 \\
26^{8}\end{array}$ & & IS; Sound \\
\hline $\mathrm{T}-107$ & 180 & 5 & $<10$ & 17 & 63 & NS; AL \\
\hline TX-118 & 347 & $<3$ & 4.9 & 24 & 76 & IS; Sound \\
\hline
\end{tabular}


Table A-1. Summary of Contents and Status of Ferrocyanide Tanks".

\begin{tabular}{|c|c|c|c|c|c|}
\hline Tank & $\begin{array}{c}\text { Total waste } \\
\text { volume } \\
(1,000 \mathrm{gal})\end{array}$ & $\begin{array}{c}\mathrm{FeCN}^{\mathrm{b}} \\
\left(1,000 \mathrm{~g} \mathrm{~mol}^{2}\right)\end{array}$ & $\begin{array}{c}\text { Heat load }(1,000 \\
\text { Btu/h })^{\mathrm{c}}\end{array}$ & $\begin{array}{l}\text { Maximum } \\
\text { temp. } \\
\left({ }^{\circ} \mathrm{C}\right) \quad\left({ }^{\circ} \mathrm{F}\right)\end{array}$ & Status of $\tan k s^{e}$ \\
\hline TY-101 & 118 & 23 & $<10$ & 64 & IS; AL \\
\hline TY -103 & 162 & 28 & $<10$ & 68 & IS; AL \\
\hline TY-104 & 46 & 12 & $<10$ & 64 & IS; $\mathrm{AL}$ \\
\hline Totals & $4,881,000 \mathrm{gal}$ & $624 \mathrm{~K} \mathrm{~g}-\mathrm{mol}$ & & & \\
\hline
\end{tabular}

- Reflects removal of four ferrocyanide tanks from Watch List in July 1993. Tank information and temperature data as of June 1993 (Hanlon 1993).

b Inventories from Borsheim and Simpson, 1991.

c Heat load values are conservatively high. New values are being calculated.

d New heat load data as of September 1992, showing low and high end of range based upon variances in thermal conductivities for waste and soil.

- IS - Interim Stabilized Tank, NS - Not Stabilized, AL - Assumed Leaker Tank, Sound - Non-Leaking Tank.

f Temperatures recorded for newly installed thermocouple trees. 


\section{DISTRIBUTION}

Number of copies

\section{OFFSITE}

12

1

1

1

1

1

1
U.S. Department of Energy

EM-35, Trevion II

Washington, D.C. 20585

John C. Tseng

U.S. Department of Energy

Savannah River Operations Office

P.O. Box A

Aiken, South Carolina 29808

Thomas C. Temple

Charles S. Abrams

1987 Virginia

Idaho Falls, ID 83404

David O. Campbell

102 Windham Road

Oak Ridge, TN 37830

Fred N. Carlson

6965 North 5th West

Idaho Falls, ID 83401

Donald T. Oakley

409 12th Street SW, Suite 310

Washington, DC 20024-2188

Arlin K. Postma

3640 Ballard Road

Dallis, Oregon 97338

William R. Prindle

1556 Crestline Drive

Santa Barbara, CA 93105 


\section{DISTRIBUTION (cont)}

Number of copies

\section{OFFSITE}

Alfred Schneider

5005 Hidden Branches Drive

Dunwoody, GA 30338

1

Air Products \& Chemicals. Inc.

7201 Hamilton Blvd

Allentown, PA 18195-1501

George E. Schmauch

1

Battelle Columbus Laboratories

505 King Avenue

Columbus, $\mathrm{OH}$ 43201-2693

James A. Gieseke

1

Brookhaven National Laboratory

Upton, NY 11973

Kamal K. Bandyopadhyay

1

Design Science, Inc.

163 Witherow Road

Sewickley, PA 15143

Gary Powers

1

Fauske and Associates, Inc. 16W070 W. 83rd St.

Burr Ridge, IL 60521

Hans K. Fauske

1

Florida State University

Department of Chemistry B-164

Tallahassee, FL 32306

Greg R. Choppin 


\section{DISTRIBUTION (cont)}

Number of copies

\section{OFFSITE}

1

Harvard University 295 Upland Avenue

Newton Highlands, MA 02161

Melvin W. First

1

Hazards Research Corporation

200 Valley Road, Suite 301

Mt. Arlington, NJ 07956

Chester Grelecki

1

4

1
Lawrence Livermore National Laboratory

P.O. Box 808, L-221

Livermore, CA 94550

Billy C. Hudson

Los Alamos National Laboratory

P.O. Box 1663

Los Alamos, NM 87545

Steve F. Agnew

Steve W. Eisenhawer

Thomas E. Larson

L. Harold Sullivan

MIT/Department of Nuclear Engineering

77 Massachusetts Ave.

Room 24-102

Cambridge, MA 02139

Mujid S. Kazimi 


\section{DISTRIBUTION (cont)}

Number of copies

\section{OFFSITE}

1

Nuclear Consulting Services, Inc.

P.O. Box 29151

Columbus, OH 43229

J. Louis Kovach

Oak Ridge National Laboratory

1

Emory D. Collins

P.O. Box 2008

7930, MS-6385

Oak Ridge, TN 37831-6385

1

Charles W. Forsberg

P.O. Box 2008

MS-6495

Oak Ridge, TN 37831-6495

1

1

5211 Paisley

Houston, TX 77096

Andrew S. Veletsos

1

Thomas S. Kress

P.O. Box 2009

9108, MS-8088

Oak Ridge, TN 37831-8088

Rice University

Sandia National Laboratory

P.O. Box 5800

Albuquerque, NM 87185

Scott E. Slezak 


\section{DISTRIBUTION (cont)}

Number of copies

ONSITE

3

Science Applications international Corporation

12850 Middlebrook Road

Trevion I, Suite 300

Germantown, MD 20874

Ray S. Daniels (3)

1

State of Washington

Department of Ecology

P. O. Box 47600

Olympia, WA $98504-7600$

Michael T. Gordon

1

University of South Carolina

Department of Electrical and Computer Engineering

Swearingen Engineering Center

Columbia, SC 29208

Joseph S. Byrd

1

University of Washington

Center for Process Analytical Chemistry

Chemistry Department BG-10

Seattle, WA 98195

Bruce R. Kowalski

1

Vanderbilt University

P.O. Box 1596, Station B

Nashville, TN 37235

Frank L. Parker 


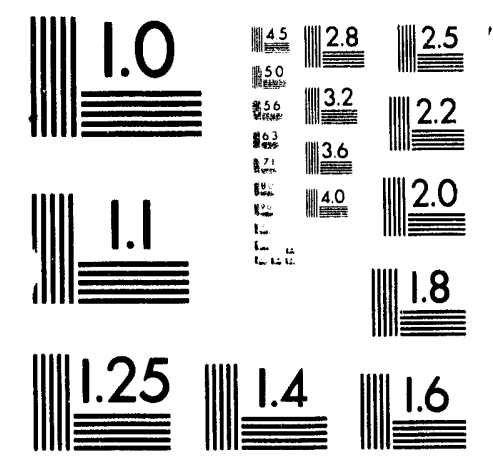



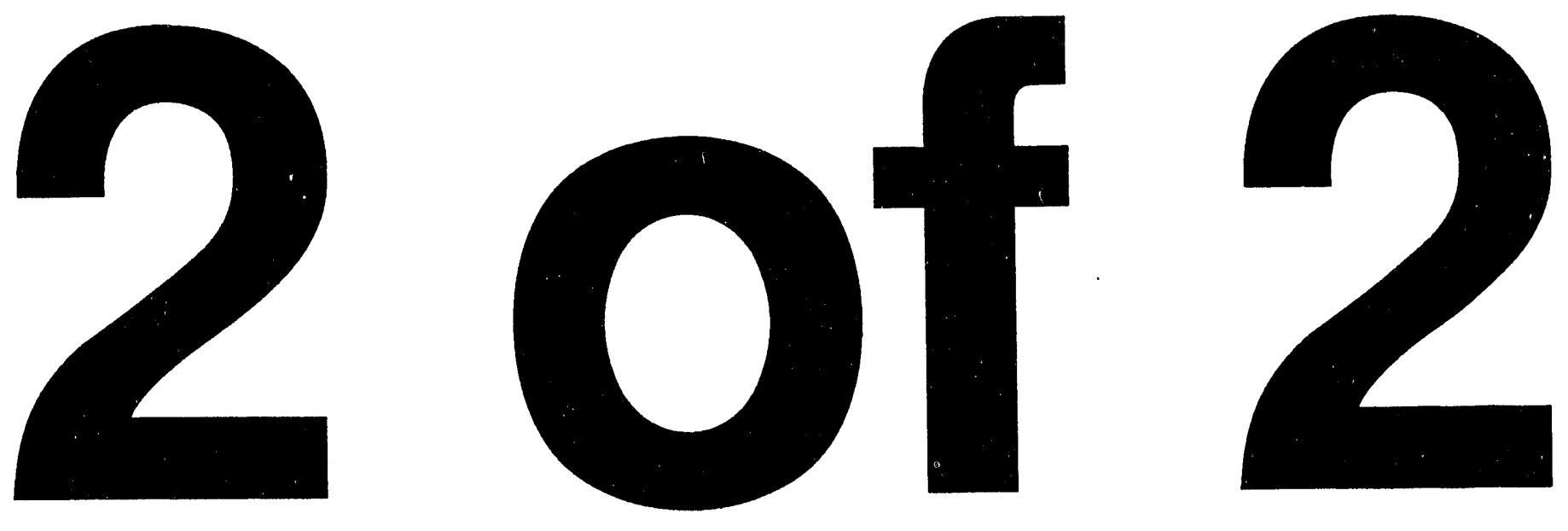


\section{DISTRIBUTION (cont)}

Number of copies

\section{QNSITE}

9

U.S. Department of Energy

Richland Field Office

R. F. Christensen (4)

R3-72

R. E. Gerton

R3-72

A. G. Krasopoulos

A4-81

Public Reading Room

H2-53

RL Docket File (2)

H5-36

8

Pacific Northwest Laboratory

R. T. Allemann

K7-15

S. A. Bryan

B. M. Johnson

P7-25

M. A. Lilga

K1-78

R. D. Scheele

P8-38

G. F. Schiefelbein

P7-25

D. M. Strachan

P8-38

Hanford Technical Library

K2-38

P8-55

49

Westinghouse Hanford Company

H. Babad

R2-78

G. A. Barnes

H5-09

J. B. Billetdeaux

R2-08

D. C. Board

S $1-57$

G. L. Borsheim

R2-11

S. R. Moreno

B3-06

R. J. Cash (2)

R2-78

M. D. Crippen

L5-31

G. M. Christensen

H4-21

D. R. Dickinson

L5-31

G. T. Dukelow

R2-78

J. C. Fulton

R2-31

K. A. Gasper

R2-08

J. M. Grigsby

$\mathrm{H} 4-62$

H. D. Harmon

R2-52

J. M. Held

R3-09

M. N. Islam

R3-08 


\section{DISTRIBUTION (cont)}

Number of copies.

\section{QNSITE}

Westinghouse Hanford Company (cont)

D. W. Jeppson

D. R. Johnson

N. W. Kirch

$\mathrm{R} 2-11$

C. A. Kuhlman

B3-30

M. Kummerer

H4-62

L. L. Lockrem

S3-90

J. D. McCormack

L5-31

J. M. McLaren

$\mathrm{H} 0-34$

J. E. Meacham

R2-78

N. J. Milliken

H4-62

T. L. Moore, Sr

H5-09

A. F. Noonan

R2-12

R. S. Popielarczyk

R1-30

T. V. Rebagay

T6-30

R. W. Reed

R1-51

F. R. Reich

L5-63

C. P. Schroeder

L7-06

B. C. Simpson

R2-12

J. P. Summerhays

R2-85

H. Toffer

H0-38

W. T. Watson

$\mathrm{H} 0-38$

W. D. Winkelman

L5-55

D. D. Wodrich

HO-30

D. D. Wodrich

R2-85

W. F. Zuroff

R2-14

Central Files

L8-04

EDMC

H6-08

Information Release Administration (3)

R1-05

TFIC

R 1 - 20 
WHC-EP-0474-9

This page intentionally left blank. 

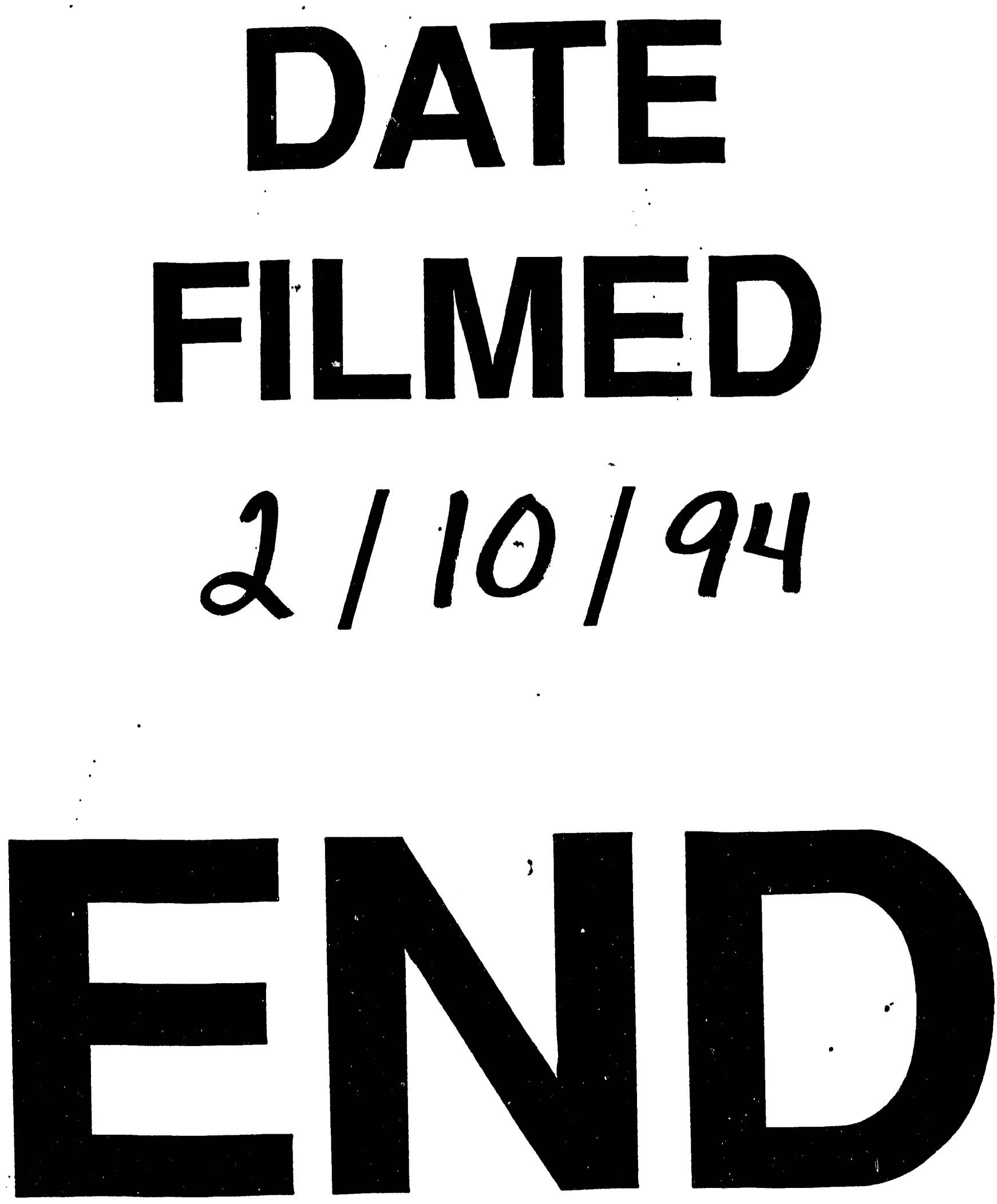
